Seri Agroforestri dan Kehutanan di Sulawesi:

Strategi mata pencaharian dan dinamika sistem penggunaan lahan di Sulawesi Tenggara

Janudianto, Noviana Khususiyah, Isnurdiansyah, S Suyanto dan James M Roshetko 



\section{Seri Agroforestri dan Kehutanan di Sulawesi: Strategi mata pencaharian dan dinamika sistem penggunaan lahan di Sulawesi Tenggara}

Janudianto, Noviana Khususiyah, Isnurdiansyah, S Suyanto dan James M Roshetko Working Paper no. 165 


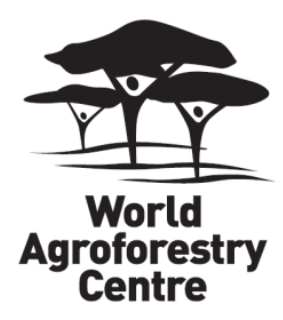

\section{Correct citation:}

Janudianto, Khususiyah N, Isnurdiansyah, Suyanto S dan Roshetko JM .2013. Seri Agroforestri dan Kehutanan di Sulawesi: Strategi mata pencaharian dan dinamika sistem penggunaan lahan di Sulawesi Tenggara [Agroforestry and Forestry in Sulawesi series: Livelihood strategies and land use sistem dynamics in Sulawesi Tenggara]. Working paper 165. Bogor, Indonesia: World Agroforestry Centre (ICRAF) Southeast Asia Wilayah Program. 43p. DOI: 10.5716/WP13041.PDF.

Titles in the Working Paper Series aim to disseminate interim results on agroforestry research and practices and stimulate feedback from the scientific community. Other publication series from the World Agroforestry Centre include: Agroforestry Perspectives, Technical Manuals and Occasional Papers.

Published by the World Agroforestry Centre

Southeast Asia Regional Program

PO Box 161, Bogor 16001

Indonesia

Tel: +62 2518625415

Fax: +62 2518625416

Email: icraf-indonesia@cgiar.org

Website: http://worldagroforestry.org/regions/southeast_asia

(C) World Agroforestry Centre 2013

Working Paper 165

\section{Photos:}

The views expressed in this publication are those of the author(s) and not necessarily those of the World Agroforestry Centre.

Articles appearing in this publication may be quoted or reproduced without charge, provided the source is acknowledged.

All images remain the sole property of their source and may not be used for any purpose without written permission of the source. 


\section{Tentang penulis}

Janudianto mendapatkan gelar sarjana S1 Pertanian, dengan fokus utama pada Ilmu Tanah, dari Fakultas Pertanian, IPB. Dia bergabung dengan ICRAF Asia Tenggara pada 2005. Dia fokus pada pengembangan strategi terkait dengan petani dan mata pencaharian masyarakat, pengelolaan sistem agroforestri tradisional---terutama memperbaiki sistem agroforestri karet---dan penilaian agroekologi keanekaragaman hayati di Sumatra, Kalimantan, dan Sulawesi. Sekarang ini Janudianto bekerja sebagai spesialis pengelolaan agroforestri di ICRAF Asia Tenggara.

Noviana Khususiyah adalah spesialis sosial ekonomi dan Livelihood di ICRAF Asia Tenggara. Dia memiliki banyak pengalaman profesional dalam survei rumah tangga, Participatory Rural Appraisals (PRA), dan Rapid Rural Appraisals (RRA). Fokus utamanya adalah mendapatkan data terkait dengan peningkatan mata pencaharian masyarakat, isu lingkungan dan gender. Dia mendapatkan gelar sarjana S2 dalam Ilmu Ekonomi (Perencanaan Pembangunan Wilayah dan Pedesaan, dengan konsentrasi pada Ekonomi Lingkungan) dari Institut Pertanian Bogor (IPB), Indonesia.

Isnurdiansyah mendapatkan gelar sarjana S1 dalam Ekonomi Agribisnis dari IPB pada 2010. Dia terlibat dalam beberapa studi sebagai konsultan bidang sosioekonomi. Dia bekerja untuk Kementerian Pertanian dari 2009 hingga 2011. Dia bergabung dengan ICRAF sebagai asisten peneliti dalam Unit Analisis Ekonomi dan Kebijakan untuk mendukung penelitian pembangunan sosioekonomi dan mata pencaharian.

S Suyanto memiliki gelar Ph.D. di bidang Ekonomi dari Tokyo Metropolitan University, Jepang. Dia saat ini menjabat sebagai Principal Scientist untuk bidang Kemiskinan, Layanan Lingkungan dan Hak Milik di ICRAF Asia Tenggara, Bogor, Indonesia. Dr. Suyanto berpengalaman selama lebih dari 15 tahun dalam pengelolaan sumber daya alam dan analisis kelembagaan. Dia sudah bekerja di Program Penelitian Wilayah Asia Tenggara untuk ICRAF yang berlokasi di Indonesia sejak 1994, dan selama itu dia sudah mengembangkan banyak keahlian dalam bidang sosioekonomi, ekonomi sumber daya alam, ekonometri, dan analisis kelembagaan. Selama lima tahun terakhir, dia mengelola beberapa proyek penelitian yang berhubungan dengan perubahan iklim dan pembayaran layanan ekosistem. Saat ini dia memimpin Unit Analisis Ekonomi dan Kebijakan di ICRAF Indonesia.

James M Roshetko adalah Senior Integrated Natural Resource Management Scientist di World Agroforestry Centre (ICRAF) dan Winrock International. Dia menjabat Kepala Unit Pohon dan Pasar ICRAF Asia Tenggara dengan 33 tahun pengalaman, termasuk 16 tahun di Indonesia dan 27 tahun di Asia Selatan dan Tenggara. Jim sekarang menjabat sebagai Pimpinan Tim Senior proyek Agroforestry and Forestry in Sulawesi: Linking Knowledge with Action yang didanai oleh CIDA. Minat penelitian dan pengembangannya berfokus pada sistem berbasis pohon yang dikelola petani skala kecil sebagai sistem pengelolaan pertanian dan sumber daya alam yang viabel dan berkontribusi secara nyata pada tujuan ekonomi lokal juga lingkungan secara global. 


\section{Abstrak}

Proyek Agroforestry and Forestry in Sulawesi: Linking Knowledge with Action (Proyek AgFor Sulawesi) dikembangkan untuk diimplementasikan di tiga provinsi di Sulawesi, Indonesia (Sulawesi Tenggara, Sulawesi Tenggara, dan Gorontalo) dari 2011 hingga 2016 dengan tujuan meningkatkan sistem mata pencaharian agroforestri dan kehutanan masyarakat pedesaan. Survei dasar ini dilakukan untuk mendukung proyek AgFor Sulawesi. Tujuan utama survei dasar ini adalah mempelajari karakteristik umum mata pencaharian masyarakat di Sulawesi Tenggara, sistem pertanian setempat, sistem penggunaan lahan berdasarkan perspektif masyarakat. Penilaian dinamika penggunaan lahan, sistem pertanian, dan strategi mata pencaharian di dua kabupaten di Sulawesi Tenggara dianggap penting untuk mendesain fase proyek selanjutnya. Dua unit analisis digunakan dalam studi dasar mata pencaharian---tingkat masyarakat dan rumah tangga.

Hasil diskusi kelompok dalam keempat tipologi desa menunjukkan hanya ada sedikit perbedaan di antara opsi mata pencaharian di desa-desa tersebut, dimana pendapatan utamanya dari budi daya kakao. Namun, ada perbedaan yang jelas dalam hal jenis tanaman dan pohon serta pengelolaan pertanian. Pada Tipologi 1 (desa lokal), tanaman utamanya terdiri dari kakao, padi, nilam, dan sagu. Tipologi 2 (desa lokal dan pendatang) memilih kakao, jagung, dan padi, sementara Tipologi 3 (desa transmigran lama) membudidayakan kakao dan lada. Penduduk Tipologi 4 (desa transmigran baru) berbeda karena mereka lebih memilih arang, kayu, dan buah-buahan daripada kakao. Sistem pengelolaan pertanian para pendatang dari Sulawesi Selatan lebih intensif daripada masyarakat asli. Sistem kakao yang digunakan oleh penduduk lokal pada Tipologi 1 kurang intensif dibandingkan dengan sistem yang dikelola oleh para pendatang dari Sulawesi Selatan pada Tipologi 2. Di keempat desa, area agroforestri kakao telah meningkat secara pesat selama 40 tahun terakhir lagi, secara umum disertai dengan penurunan signifikan area hutan.

Dari hasil survei rumah tangga disimpulkan bahwa pendapatan total rata-rata per tahun per rumah tangga pada desa Tipologi 1 lebih rendah daripada dari semua daerah tetangga. Pendapatan per kapita harian para petani pada desa Tipologi 1 juga lebih rendah daripada petani lain yang menghasilkan pendapatan cukup tinggi dari sumber yang berbeda.

Kata kunci: Proyek AgFor Sulawesi, Sulawesi Tenggara, dinamika penggunaan lahan, mata pencaharian, pendapatan, petani setempat, petani pendatang, agroforestri kakao 


\section{Ucapan terima kasih}

Studi ini dilakukan sebagai bagian dari proyek Agroforestry and Forestry in Sulawesi: Linking Knowledge with Action (Proyek AgFor Sulawesi) yang diimplementasikan oleh World Agroforestry Centre (ICRAF) dan didanai terutama oleh Canadian International Development Agency (CIDA).

Para penulis ingin berterima kasih kepada Adriyanto Pratama, M Erik Kurniawan, Laode Ali Said, Heru T Maulana, Syamsidar, dan Rahma R Talui untuk kontribusi mereka dalam wawancara rumah tangga dan memfasilitasi diskusi kelompok. Terima kasih kepada Elok Mulyoutami, Endri Martini, Jusupta Tarigan, dan Anang Setiawan atas diskusi yang bermanfaat pada saat kegiatan lapangan. Para penulis juga sangat menghargai dukungan luar biasa dari Proyek AgFor Sulawesi Tim Kendari dan para kepala desa di Kabupaten Konawe dan Kolaka. Ucapan terima kasih terutama ditujukan kepada para penduduk desa dan petani di Sulawesi Tenggara yang berpartisipasi dalam diskusi, wawancara, dan pengamatan lapangan. 



\section{Daftar Isi}

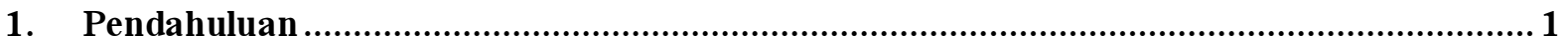

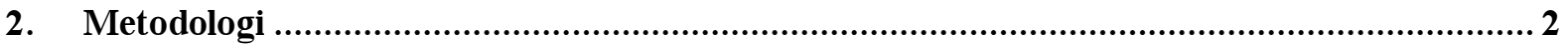

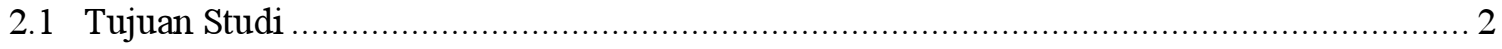

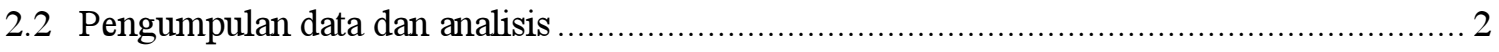

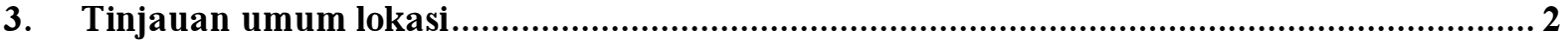

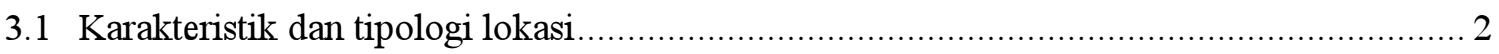

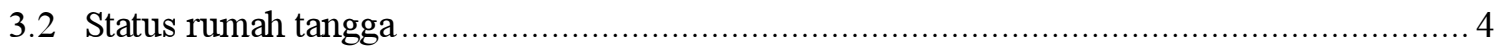

4. Sejarah desa dan dinamika penggunaan lahan di Sulawesi Tenggara ................................ 9

4.1 Perspektif masyarakat mengenai sejarah desa dan dinamika penggunaan lahan di Sulawesi

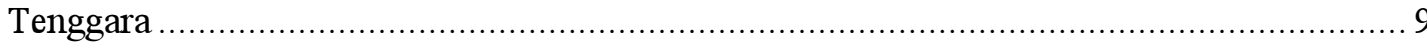

4.2 Perspektif rumah tangga mengenai karakteristik lahan dan penggunaan lahan................. 21

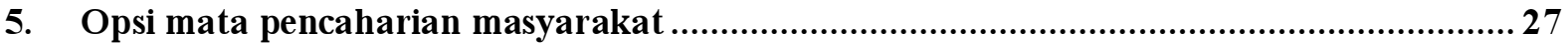

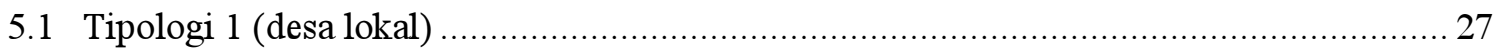

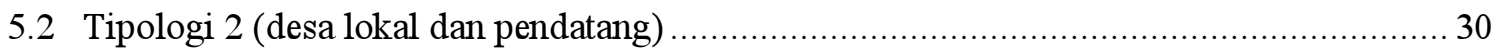

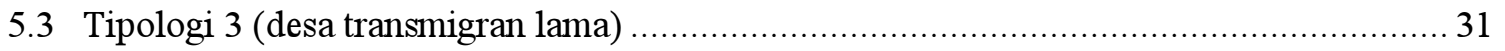

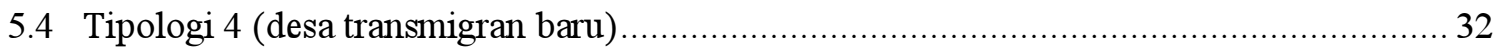

5.5 Indikator penting mata pencaharian berdasarkan survei rumah tangga ........................... 34

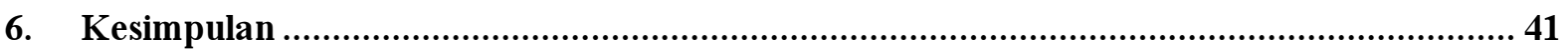

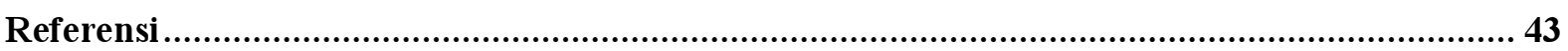




\section{Daftar Gambar}

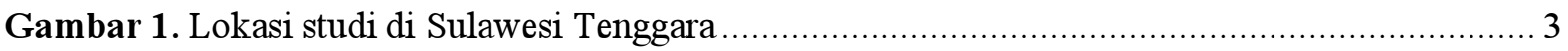

Gambar 2. Struktur dinding rumah di Sulawesi Tenggara ...................................................... 4

Gambar 3. Atap rumah di Sulawesi Tenggara................................................................. 5

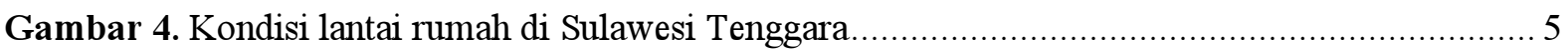

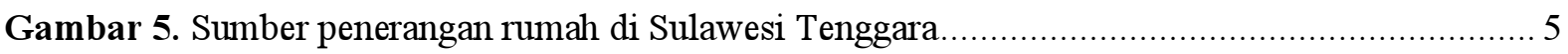

Gambar 6. Distribusi gender dalam rumah tangga di Sulawesi Tenggara .................................... 8

Gambar 7. Etnis kepala rumah tangga di Sulawesi Tenggara ............................................... 8

Gambar 8. Penggunaan lahan terkini di Desa Ambondiaa berdasarkan perspektif masyarakat......... 10

Gambar 10. Penggunaan lahan terkini di Desa Lamunde berdasarkan perspektif masyarakat .......... 11

Gambar 11. Dinamika penggunaan lahan in Lamunde berdasarkan perspektif masyarakat ............. 11

Gambar 12. Penggunaan lahan terkini di Desa Simbune berdasarkan perspektif masyarakat .......... 12

Gambar 13. Dinamika penggunaan lahan di Simbuneberdasarkan perspektif masyarakat.............. 12

Gambar 14. Penggunaan lahan terkini di Desa Taosu berdasarkan perspektif masyarakat .............. 13

Gambar 15. Dinamika penggunaan lahan di Taosu berdasarkan perspektif masyarakat ................. 13

Gambar 16. Penggunaan lahan terkini di Desa Wonua Hoa berdasarkan perspektif masyarakat ...... 14

Gambar 17. Dinamika penggunaan lahan di Wonua Hoa berdasarkan perspektif masyarakat .......... 14

Gambar 18. Penggunaan lahan terkini di Desa Anggawo berdasarkan perspektif masyarakat .......... 15

Gambar 19. Dinamika penggunaan lahan di Anggawo berdasarkan perspektif masyarakat............. 16

Gambar 20. Penggunaan lahan terkini di Desa Lawonua berdasarkan perspektif masyarakat.......... 16

Gambar 21. Dinamika penggunaan lahan di Lawonua berdasarkan perspektif masyarakat ............. 17

Gambar 22. Penggunaan lahan terkini di Tasahea berdasarkan perspektif masyarakat................... 18

Gambar 23. Dinamika penggunaan lahan di Tasahea berdasarkan perspektif masyarakat............... 18

Gambar 24. Penggunaan lahan terkini di Lalobite berdasarkan perspektif masyarakat.................... 19

Gambar 25. Dinamika penggunaan lahan di Lalobite berdasarkan perspektif masyarakat............... 19

Gambar 26. Penggunaan lahan terkini di UPT Asinua Jaya berdasarkan perspektif masyarakat...... 20

Gambar 27. Dinamika penggunaan lahan di UPT Asinua Jaya berdasarkan perspektif masyarakat.. 20

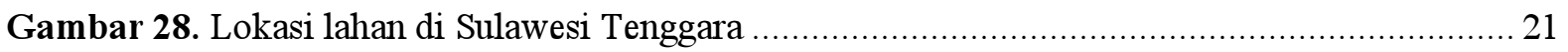

Gambar 29. Waktu berjalan kaki dari rumah menuju ke lahan di Sulawesi Tenggara ..................... 21

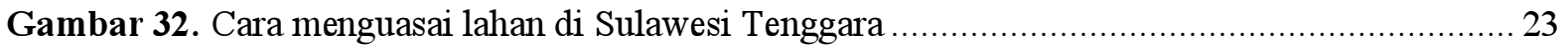

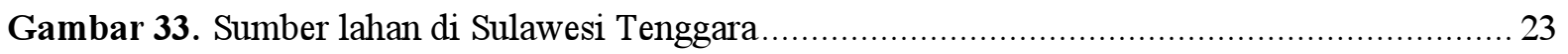

Gambar 34. Tahun penguasaan lahan di Sulawesi Tenggara .................................................... 24

Gambar 35. Status kepemilikan lahan saat ini di Sulawesi Tenggara ........................................ 24

Gambar 36. Pola penggunaan lahan sebelum saat ini di Sulawesi Tenggara ............................... 25 


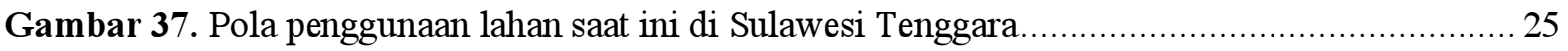

Gambar 38. Pola penggunaan lahan sebelum dikuasai di Sulawesi Tenggara ….......................... 26

Gambar 39. Pola penggunaan lahan satu tahun setelah dikuasai di Sulawesi Tenggara.................. 26

Gambar 40. Opsi mata pencaharian terkini di Ambondiaa, Lamunde, Simbune, Taosu, dan Wonua

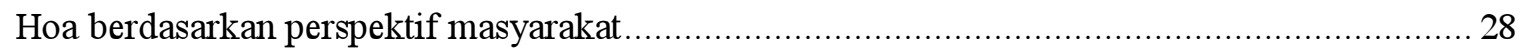

Gambar 41. Opsi mata pencaharian terkini di Anggawo dan Lawonua berdasarkan perspektif

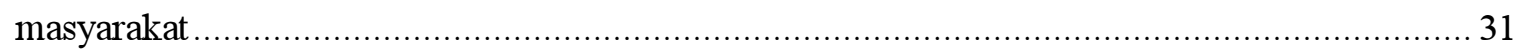

Gambar 42. Opsi mata pencaharian terkini di Tasahea berdasarkan perspektif masyarakat............. 32

Gambar 43. Opsi mata pencaharian terkini di Lalobite dan UPT Asianua Jaya berdasarkan

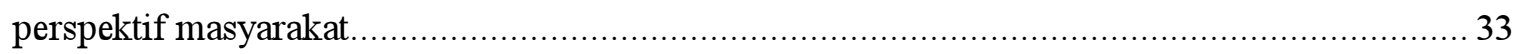

Gambar 44. Sumber pendapatan berdasarkan tipe kegiatan di Sulawesi Tenggara pada 2012 ......... 37

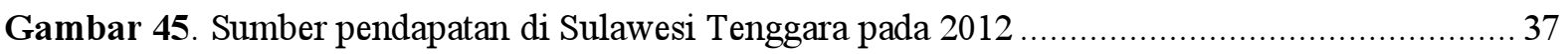

Gambar 46. Rata-rata pendapatan per kapita per hari masyarakat di Sulawesi Tenggara pada 2012. 38

Gambar 47. Distribusi kepemilikan lahan rata-rata per rumah tangga di Sulawesi Tenggara........... 38

Gambar 48. Alasan lahan tidak digarap/dikosongkan di Sulawesi Tenggara................................ 39

Gambar 49. Lama lahan tidak digarap/dikosongkan di Sulawesi Tenggara.................................. 40

\section{Daftar Tabel}

Tabel 1. Tipologi desa dan detail FGD dan penyelenggaraan survei rumah tangga di Sulawesi

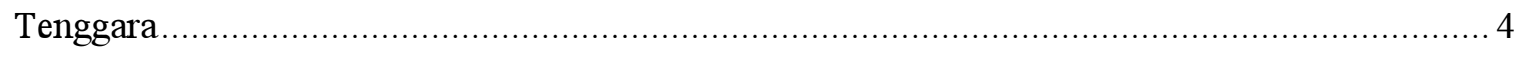

Tabel 2. Tingkat pendidikan kepala rumah tangga dan istri di Sulawesi Tenggara .......................... 6

Tabel 3. Distribusi pendidikan anak di Sulawesi Tenggara .................................................... 7

Tabel 4. Distribusi rata-rata jumlah tanaman per hektar di Sulawesi Tenggara ................................ 27

Tabel 5. Rata-rata pendapatan masyarakat berdasarkan sumber pendapatan di Sulawesi Tenggara

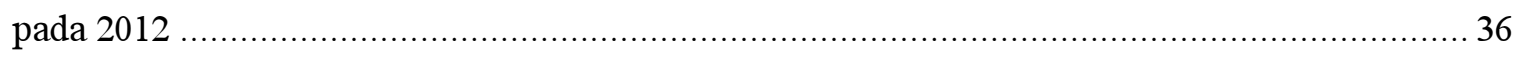

Tabel 6. Distribusi luas penguasaan lahan berdasarkan penggunaan lahan di Sulawesi Tenggara ..... 38 



\section{Pendahuluan}

Proyek Agroforestry and Forestry in Sulawesi: Linking Knowledge with Action (Proyek AgFor Sulawesi) sedang diimplementasikan di tiga provinsi di Sulawesi, Indonesia (Sulawesi Tenggara, Sulawesi Tenggara, dan Gorontalo) dari 2011 hingga 2016. Tujuan utama implementasi ini adalah meningkatkan sistem mata pencaharian agroforestri dan kehutanan masyarakat pedesaan sasaran (Roshetko et al. 2012).

Tantangan utama dalam proyek ini adalah kurangnya keragaman sistem mata pencaharian pedesaan, ketergantungan tinggi masyarakat pedesaan akan tanaman komoditas eksotis, dan kerentanan pada risiko (biologis dan pasar) yang datang bersamaan. Sistem agroforestri yang beragam pada lanskap yang dikelola dengan baik, dengan tingkat intensitas mulai dari sawah yang intensif hingga hutan alami, secara umum dianggap sebagai sistem yang lebih kokoh dan terhindar dari risiko. Proyek ini bertujuan untuk menerapkan sistem tersebut dalam 3 provinsi yang telah disebutkan. Lebih jauh lagi, pengelolaan daerah aliran sungai (DAS) yang kurang optimal menyebabkan peningkatan erosi tanah, sedimentasi, longsor, dan banjir.

Kedua, analisis mengindikasikan bahwa Sulawesi akan mengalami variasi yang substansial dalam kondisi atmosfer sekarang, lebih memperburuk masalah DAS. Pengelolaan DAS yang ditingkatkan dan strategi adaptasi untuk petani setempat diperlukan untuk mengamankan mata pencaharian dan melindungi lingkungan. Insentif yang membantu pengembangan program layanan lingkungan harus diciptakan.

Ketiga, orang-orang yang termarginalisasi tidak memiliki cukup hak atas tanah mereka dan memiliki sedikit kesadaran akan, atau akses pada, penghubung untuk sertifikasi atau klarifikasi status lahan. Hal ini melanggengkan kerentanan dan menghambat investasi. Serupa dengan itu, hak perempuan juga seringkali dipinggirkan atau diabaikan, mengindikasikan adanya kebutuhan khusus untuk peningkatan kesadaran dan pemberdayaan. Perambahan yang berlanjut ke dalam area hutan dilihat sebagai pendorong utama deforestasi dan menunjukkan gejala konflik yang lebih luas di antara masyarakat dengan pemerintah.

Keempat, kapasitas tata kelola setempat lemah. Banyak kabupaten yang tidak siap menghadapi desentralisasi dan demokratisasi. Setelah 10 tahun, banyak kapasitas setempat yang sudah dikembangkan, tetapi pemerintahan mandiri masih dipahami lebih sebagai hak dan bukan tanggung jawab. Usaha pembangunan masih tidak memiliki visi jangka panjang penting yang cukup untuk mencapai keberlanjutan. Partisipasi masyarakat dalam perencanaan penggunaan lahan pemerintah masih jarang terjadi, sama halnya dengan insentif dan keuntungan yang relevan untuk masyarakat tersebut (Roshetko et al. 2012).

Survei dasar dilakukan untuk mendukung proyek ini. Survei ini bertujuan untuk mempelajari karakteristik mata pencaharian, sistem pertanian setempat, dan sistem penggunaan lahan terkini berdasarkan perspektif masyarakat. Penilaian dinamika penggunaan lahan, sistem pertanian, dan strategi mata pencaharian di dalam kabupaten-kabupaten terpilih di Provinsi Sulawesi Tenggara dirasakan sangat penting untuk mendesain fase proyek selanjutnya. Hal ini juga penting untuk memberikan tinjauan strategi yang dipilih dan kecocokan strategi itu dalam kondisi setempat. Dua unit analisis digunakan dalam studi dasar mata pencaharian---tingkat masyarakat dan rumah tangga. 
Studi ini menyajikan perspektif masyarakat mengenai dinamika penggunaan lahan, sistem pertanian, strategi mata pencaharian, dan data yang lebih terperinci mengenai beragam aspek terkait dengan rumah tangga di Sulawesi Tenggara.

\section{Metodologi}

\subsection{Tujuan Studi}

Tujuan utama studi ini adalah:

- Mengidentifikasi karakteristik umum mata pencaharian, sistem pertanian, dan sistem penggunaan lahan lain di area tersebut berdasarkan perspektif masyarakat.

- Melakukan identifikasi tersebut menggunakan survei rumah tangga.

\subsection{Pengumpulan data dan analisis}

Data didapatkan dengan diskusi kelompok terarah (FGD) di tiap desa sampel di 2 kabupaten di Provinsi Sulawesi Tenggara. FGD berjalan sepanjang hari dengan diikuti oleh rata-rata delapan petani dalam tiap kelompok. Para partisipan terdiri dari anggota desa yang paling memahami kondisi setempat. Topik diskusi berkisar antara demografik, sejarah, sistem penggunaan lahan, sumber mata pencaharian, dan praktik pengelolaan lahan desa.

Informasi tingkat rumah tangga dikumpulkan dari 30 rumah tangga menggunakan stratifikasi acak dari 6 desa di Sulawesi Tenggara (Tabel 1). Setiap kali memungkinkan, suami dan istri dari tiap rumah tangga diwawancarai bersama-sama. Rinciannya dijelaskan dalam bagian selanjutnya.

\section{Tinjauan umum lokasi}

\subsection{Karakteristik dan tipologi lokasi}

Provinsi Sulawesi Tenggara berlokasi di bagian tenggara semenanjung Sulawesi dan terdiri dari beberapa pulau kecil termasuk Buton dan Muna, dan islet (pulau sangat kecil) termasuk Wowoni dan Kabaena. Daratan Sulawesi Tenggara mencakup sekitar $38140 \mathrm{~km}^{2}$ dan area pulau kecil diperkirakan meliputi area seluas $114876 \mathrm{~km}^{2}$. Konawe, Kolaka, dan Bombana adalah kabupaten utama di daratan, dan Kendari adalah ibu kota provinsi. Proyek AgFor Sulawesi berfokus pada Kabupaten Konawe dan Kolaka (Gambar 1). 


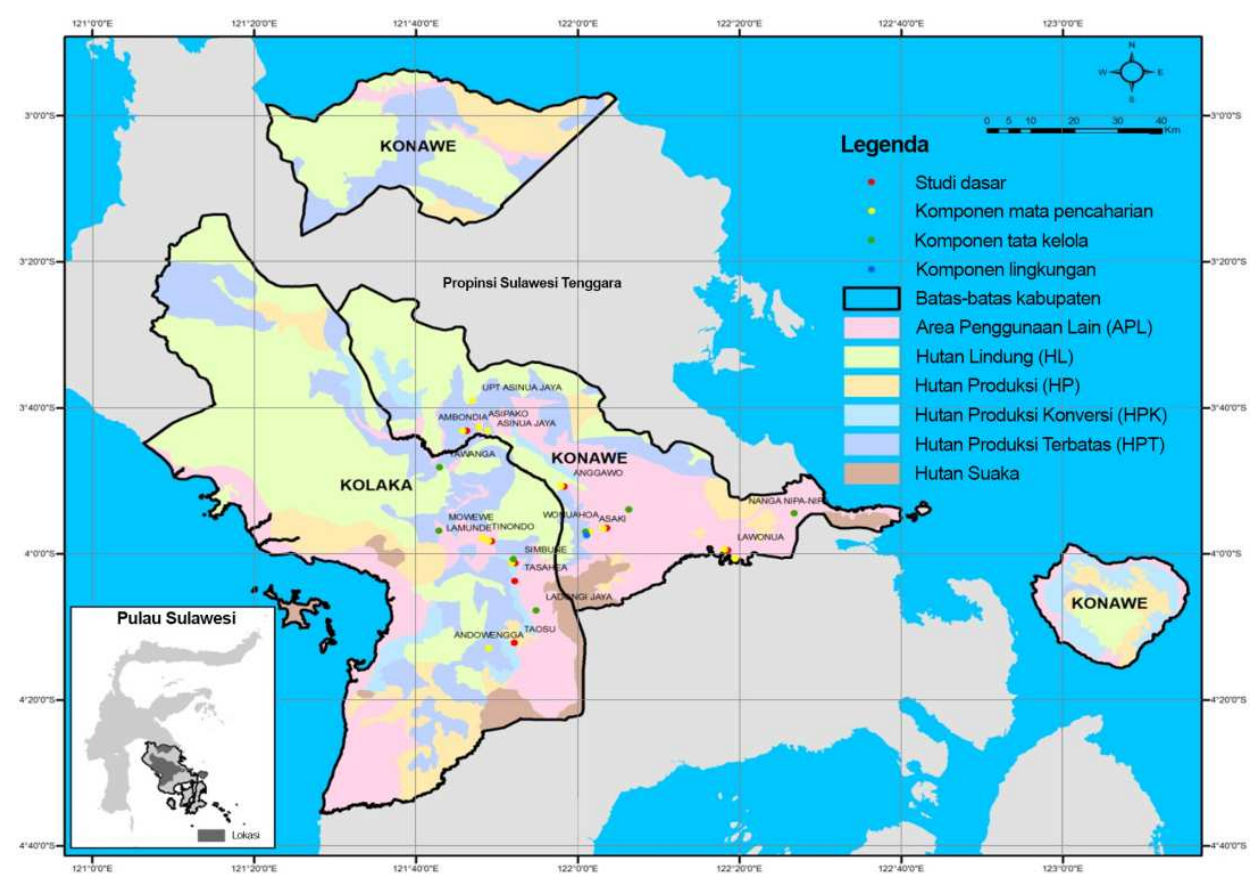

Gambar 1. Lokasi studi di Sulawesi Tenggara

Pada 2007, sektor pertanian Sulawesi Tenggara memberikan kontribusi 38\% pada pertumbuhan ekonomi daerah tersebut (dari singkong dan jagung, dan komoditas seperti kakao, kopi, kelapa, cengkeh, kacang mete, lada, dan kelapa sawit). Data dari tahun yang sama menunjukkan hampir

240000 ton singkong diproduksi dari area budi daya seluas 15000 ha dan 97037 ton jagung dari lahan seluas 40975 ha. Dari produksi singkong total, Kabupaten Konawe memberikan kontribusi 5\%, sementara Kolaka memberikan kontribusi 3,3\%. Buton menghasilkan produksi singkong terbesar, sekitar 76709 ton dari lahan seluas 4785 ha. Produsen jagung terbesar di Sulawesi Tenggara adalah Buton (13 990 ton), diikuti oleh Kolaka (6 454 ton), Buton Utara (5 863 ton), Kendari (3 569 ton), dan Konawe (3 297 ton) (BPS Sulawesi Tenggara 2008).

Produksi kelapa sawit di Sulawesi Tenggara berkonsentrasi di Kolaka, dari daerah yang mencakup sekitar 21033 ha dengan produksi mencapai sekitar 7220 ton. Produktivitas kakao di Sulawesi Tenggara pada 2010 mencapai sekitar 137833 ton, dengan area produksi kakao terbesar di Kolaka (91 259 ha), dan Kolaka Utara (82 206). Kabupaten lain juga memproduksi kakao dari lahan seluas kurang dari 10000 ha. Produksi terbesar berasal dari Kolaka Utara yang menghasilkan 63101 ton pada 2009 dan Kolaka yang memproduksi 29297 ton pada 2009. Pada 2010, produksi lada di Sulawesi Tenggara melingkupi 5371 ton, dari area total 11775 ha, dengan sekitar 99\% hasil produksi berasal dari petani skala kecil. Konawe memberikan kontribusi 1317 ton (24,5\%) dari lahan seluas 3661 ha dan Konawe memberikan kontribusi sebanyak nyaris 40\% dari produksi total Sulawesi Tenggara.

Mata pencaharian masyarakat Sulawesi Tenggara sangat terkait dengan sejarah, demografi, dan migrasi. Masyarakat dari beragam latar belakang etnis, kelompok masyarakat asli, dan masyarakat pendatang menerapkan strategi dan sumber mata pencaharian yang berbeda. Penjelasan tipologi masyarakat dalam provinsi ini juga harus mempertimbangkan isu migrasi, seperti yang diperlihatkan dalam Tabel 1. 
Tabel 1. Tipologi desa dan detail FGD dan penyelenggaraan survei rumah tangga di Sulawesi Tenggara

\begin{tabular}{|c|c|c|c|c|c|}
\hline \multirow[t]{2}{*}{ Tipologi desa } & Lokal & $\begin{array}{l}\text { Lokal dan } \\
\text { migran }\end{array}$ & $\begin{array}{c}\text { Transmigran } \\
\text { (Iama) }\end{array}$ & Migran (baru) & \multirow{2}{*}{$\begin{array}{l}\text { Total grup/ } \\
\text { responden } \\
\text { rumah tangga }\end{array}$} \\
\hline & 1 & 2 & 3 & 4 & \\
\hline Kabupaten & Konawe, Kolaka & Konawe & Kolaka & Konawe & \\
\hline $\begin{array}{l}\text { FGD dan jumlah } \\
\text { diskusi }\end{array}$ & $\begin{array}{l}\text { Ambondiaa, } \\
\text { Lamunde, } \\
\text { Simbune, Taosu, } \\
\text { Wonua Hoa (5) }\end{array}$ & $\begin{array}{l}\text { Anggawo, } \\
\text { Lawonua (2) }\end{array}$ & Tasahea (1) & $\begin{array}{l}\text { Lalobite, UPT } \\
\text { Asinua Jaya (2) }\end{array}$ & $\begin{array}{c}10 \text { diskusi } \\
\text { dalam } 9 \text { desa }\end{array}$ \\
\hline $\begin{array}{l}\text { Wawancara rumah } \\
\text { tangga dan jumlah } \\
\text { responden }\end{array}$ & $\begin{array}{l}\text { Amb ondiaa (30) } \\
\text { Simbune (30) } \\
\text { Wonua Hoa (30) }\end{array}$ & Lawonua (30) & Tasahea (30) & Lalobite (30) & $\begin{array}{l}180 \text { rumah } \\
\text { tangga }\end{array}$ \\
\hline
\end{tabular}

\subsection{Status rumah tangga}

\subsubsection{Kondisi rumah}

Kondisi rumah para petani dapat digunakan untuk memperkirakan kesejahteraan mereka. Kondisi rumah dinilai dengan menggunakan 4 variabel: tipe dinding, atap, lantai, dan penerangan (Gambar 2 5). Kondisi rumah di desa lokal (selanjutnya dirujuk sebagai Tipologi 1) adalah paling buruk dibandingkan dengan rumah-rumah pada tipologi lain. Kondisi rumah-rumah di desa lokal dan pendatang (Tipologi 2), desa transmigran (Tipologi 3), dan desa pendatang (Tipologi 4) relatif sama.

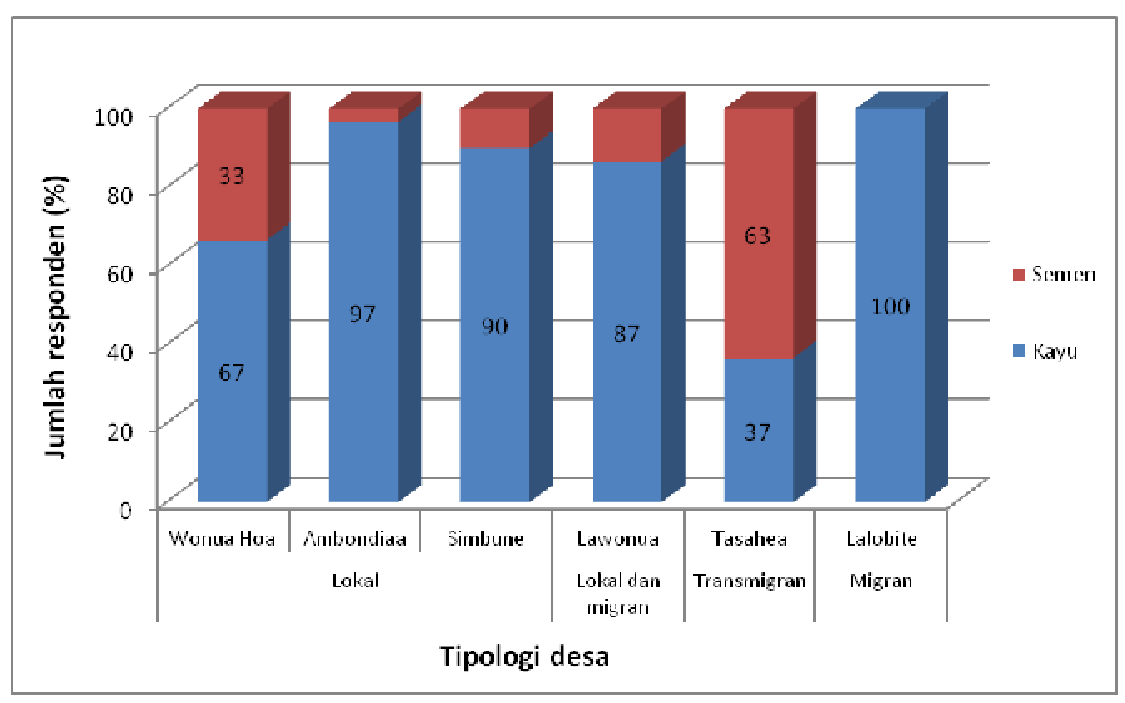

Gambar 2. Struktur dinding rumah di Sulawesi Tenggara 


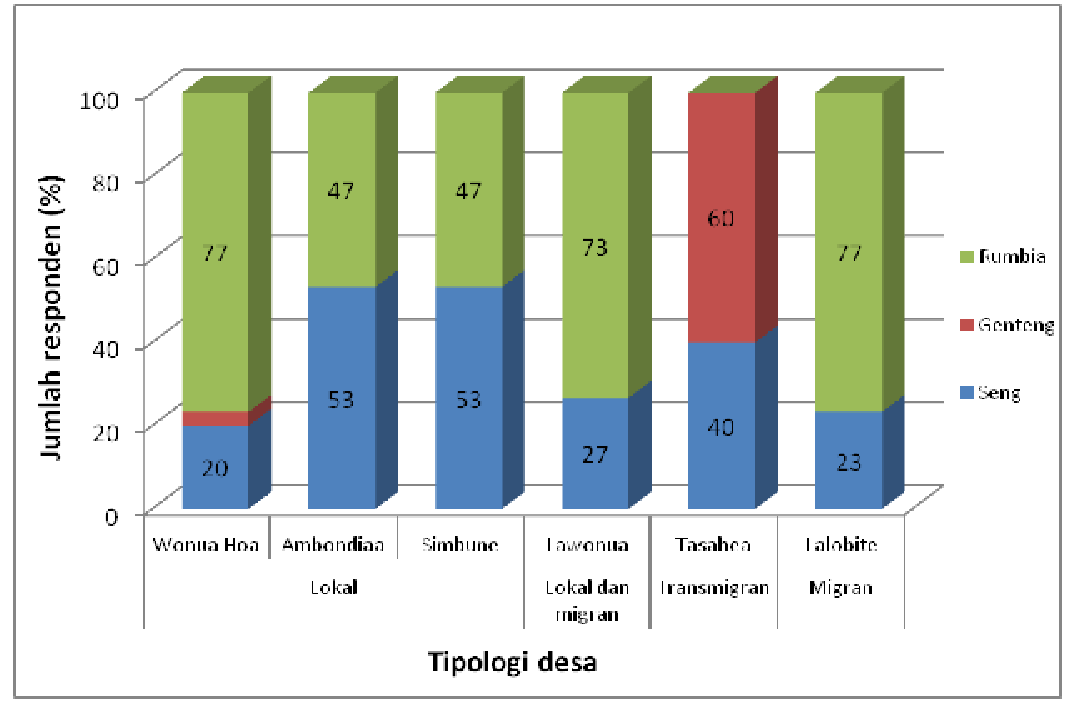

Gambar 3. Atap rumah di Sulawesi Tenggara

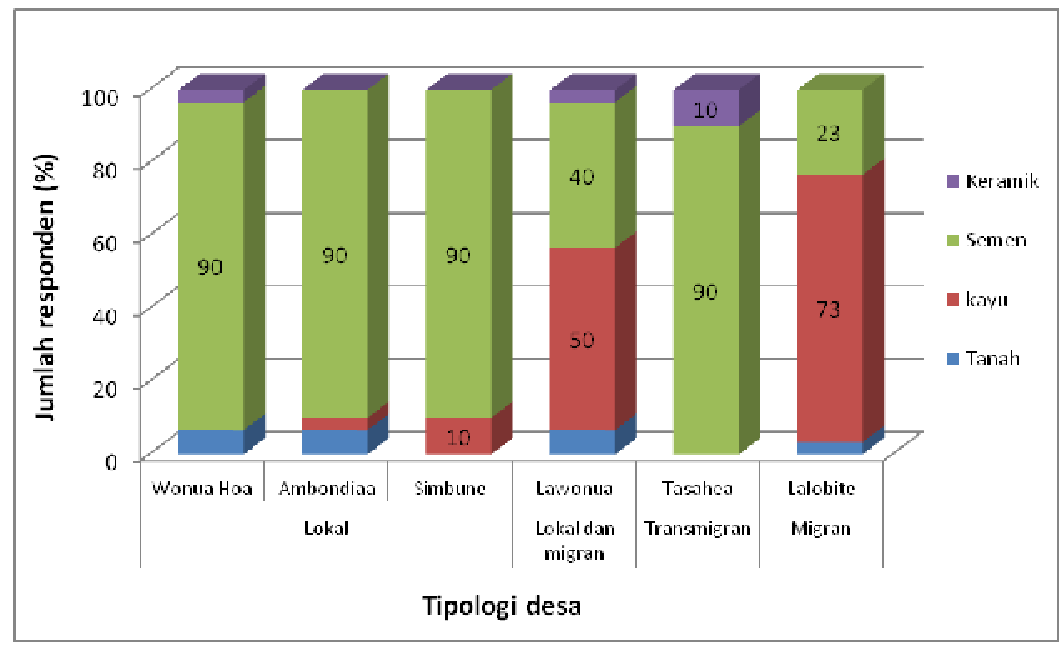

Gambar 4. Kondisi lantai rumah di Sulawesi Tenggara

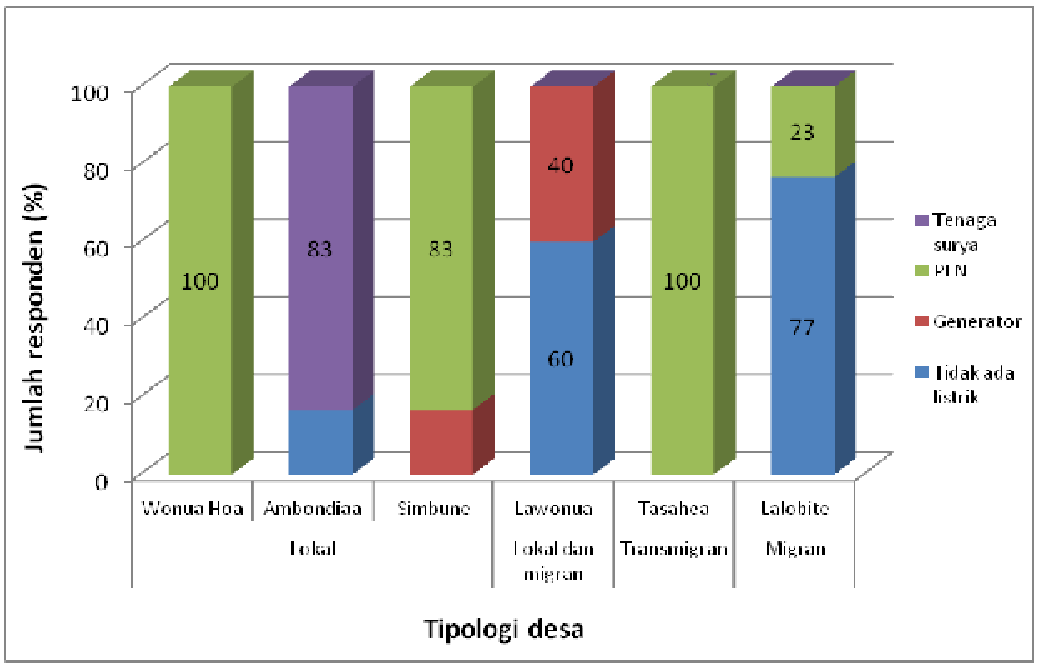

Gambar 5. Sumber penerangan rumah di Sulawesi Tenggara 


\subsubsection{Pendidikan}

Tingkat pendidikan pada Tipologi 4 adalah yang terendah dibandingkan dengan responden lain. Tingkat pendidikan pada tipologi-tipologi lain relatif sama. Tingkat pendidikan perempuan sedikit lebih rendah dibandingkan laki-laki. Namun, analisis statistik menunjukkan tidak ada perbedaan signifikan dalam tingkat pendidikan di antara laki-laki dan perempuan di semua desa (hanya anak laki-laki dan perempuan pada Tipologi 4).

Sebagian besar responden di Sulawesi Tenggara, termasuk para suami dan istri, memiliki tingkat pendidikan sedang (Tabel 2). Rata-rata lama pendidikan pada Tipologi 1 adalah 8,2-9,1 tahun untuk laki-laki dan 7,0-9, tahun untuk perempuan. Pada Tipologi 2, rata-rata lama pendidikan adalah 6,4 tahun untuk laki-laki dan 5,7 tahun untuk perempuan. Pada Tipologi 3, rata-rata lama pendidikan adalah 4,8 untuk laki-laki dan 4,5 tahun untuk perempuan. Tipologi 4 memiliki rata-rata lama pendidikan lebih tinggi---6,8 dan 6,7 tahun untuk laki-laki dan perempuan secara berurutan. Tingkat buta huruf tertinggi berada pada Tipologi 3 (14\% untuk laki-laki dan 17\% untuk perempuan). Namun, hasil dari analisis data menggunakan "uji $t$ " menunjukkan tidak ada perbedaan signifikan dalam tingkat pendidikan antara laki-laki dan perempuan.

Tabel 2. Tingkat pendidikan kepala rumah tangga dan istri di Sulawesi Tenggara

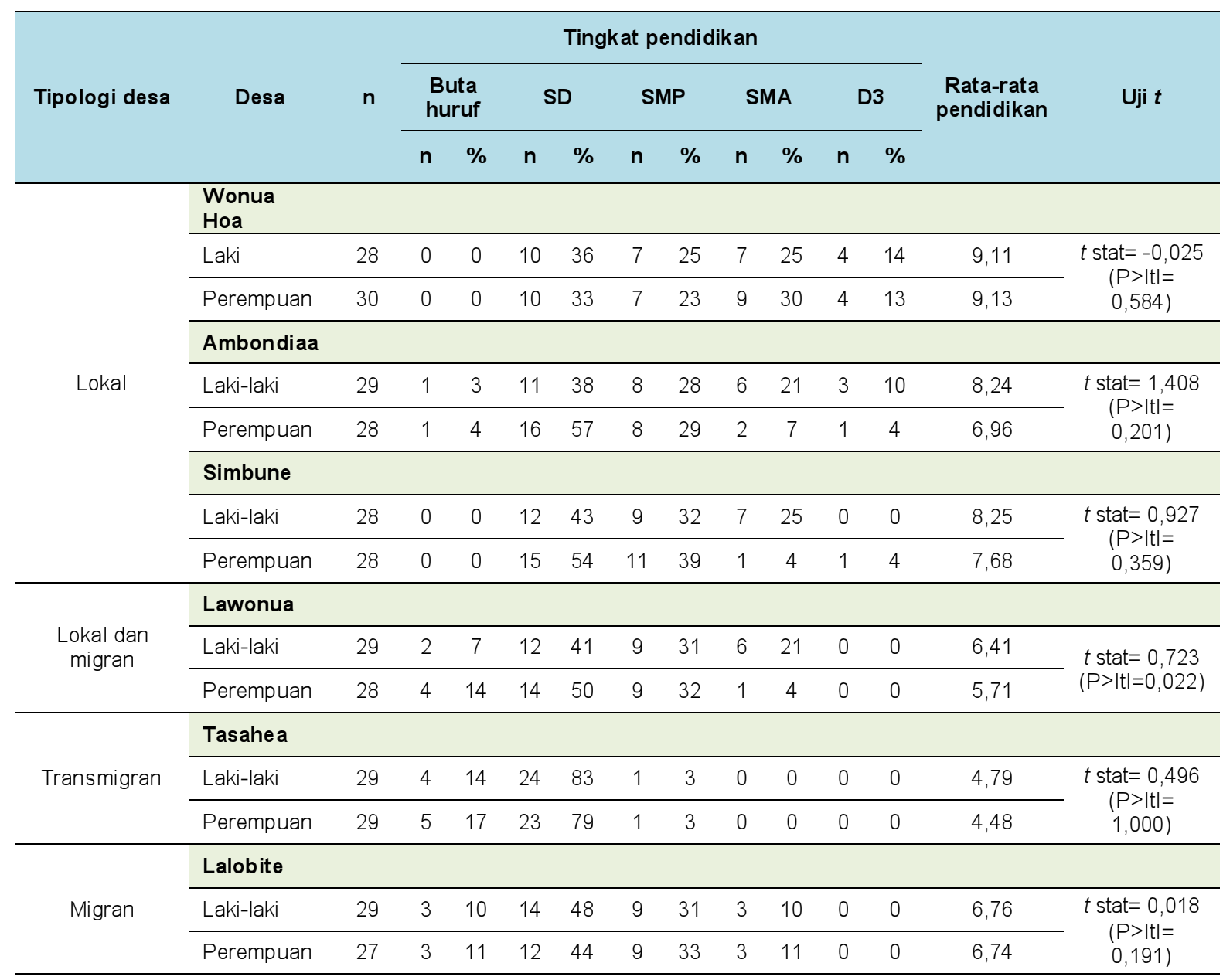


Kami juga menghitung distribusi pendidikan dari anak-anak responden di setiap tipologi (Tabel 3). Hasil dari analisis data menggunakan uji $t$ menunjukkan satu-satunya perbedaan signifikan berada pada Tipologi 4.

Tabel 3. Distribusi pendidikan anak di Sulawesi Tenggara

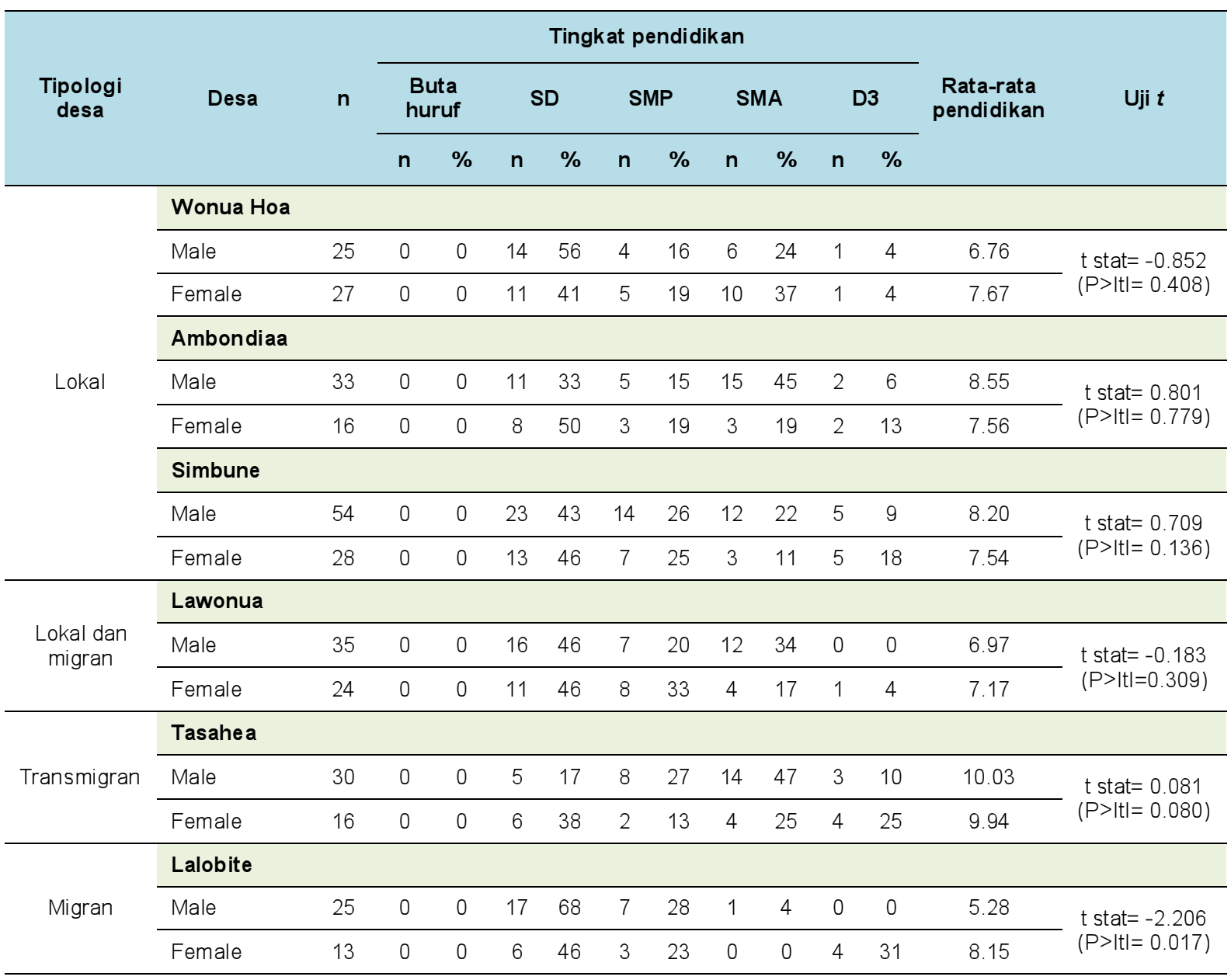

\subsubsection{Distribusi gender dalam rumah tangga}

Jumlah anggota rumah tangga laki-laki dan perempuan di desa lokal dalam semua tipologi relatif sama. Semua desa memiliki sedikit lebih banyak laki-laki daripada perempuan, kecuali di Desa Wonua Hoa (Tipologi 1), yang memiliki lebih banyak perempuan (Gambar 6). 


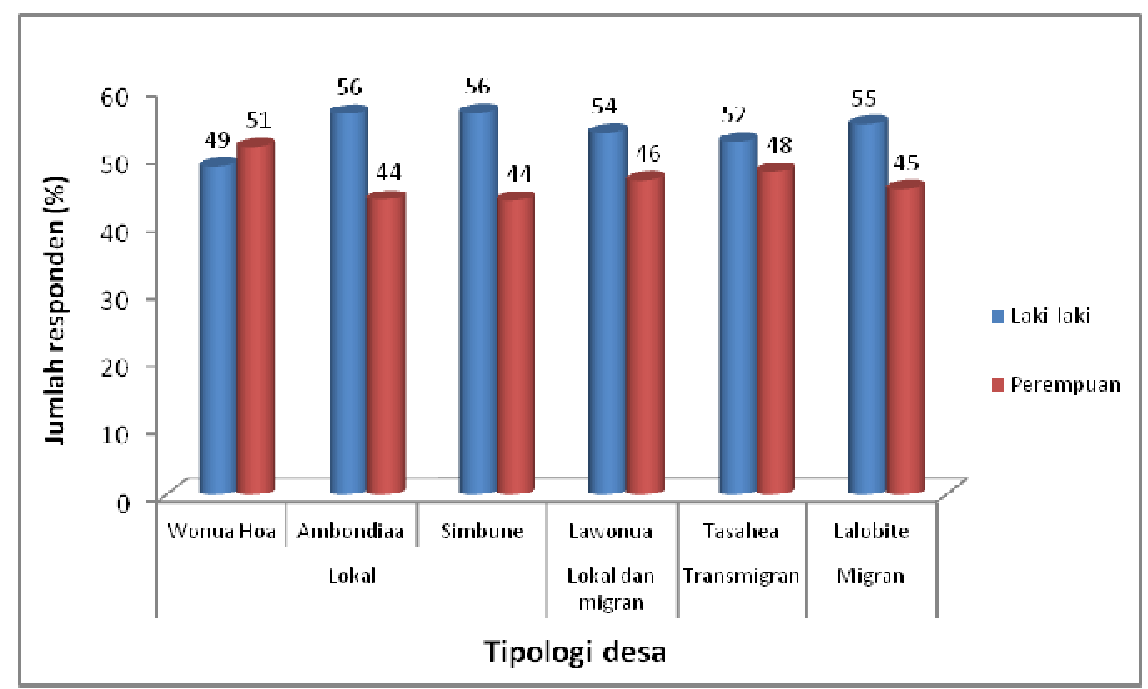

Gambar 6. Distribusi gender dalam rumah tangga di Sulawesi Tenggara

\subsubsection{Etnis kepala rumah tangga}

Kebanyakan kepala rumah tangga berasal dari suku Tolaki pada Tipologi 1, Tolaki dan Bugis pada Tipologi 2, Bali pada Tipologi 3, dan Bugis pada Tipologi 4. Data etnis kepala rumah tangga dirangkum dalam Gambar 7.

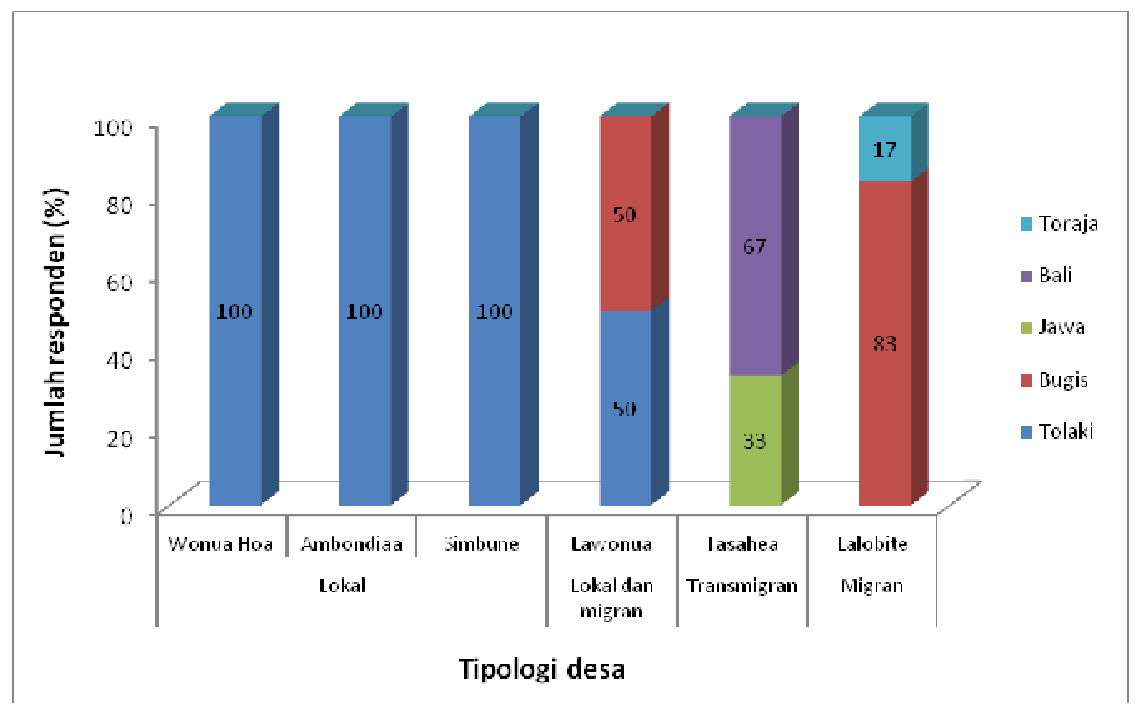

Gambar 7. Etnis kepala rumah tangga di Sulawesi Tenggara 


\section{Sejarah desa dan dinamika penggunaan lahan di Sulawesi Tenggara}

Bab ini membahas sejarah umum desa dan sistem penggunaan lahan utama. Agroforestri kakao mendominasi di sebagian besar desa walaupun padi menjadi tanaman penting pada Tipologi 1. Tutupan hutan juga banyak ditemukan dalam kebanyakan tipologi kecuali di Desa Lawonua. Walaupun sagu merupakan tanaman penting untuk ketahanan pangan pada Tipologi 1 dan 2, sagu tidak diidentifikasi sebagai sistem penggunaan lahan utama karena tanaman ini hanya dibudidayakan sesekali, contohnya pada tepian sungai.

\subsection{Perspektif masyarakat mengenai sejarah desa dan dinamika penggunaan lahan di Sulawesi Tenggara}

\subsubsection{Tipologi 1 (desa lokal)}

Desa-desa ini (Ambondiaa, Lamunde, Simbune, Taosu, dan Wonua Hoa) diidentifikasi sebagai desa "lokal" terkait dengan populasi yang dominan dan pengaruh pendatang. Suku asli Tolaki mendominasi. Dalam 5 desa pada tipologi ini, tercatat adanya sedikit gelombang pendatang dari masyarakat luar.

Sekarang ini desa-desa ini masih memiliki daerah tutupan hutan yang luas. Hukum adat mengenai perlindungan hutan memainkan peranan penting dalam mata pencaharian pedesaan dan, kemungkinan besar, hukum ini akan mengarahkan perubahan substansial dalam cara pengelolaan hutan. Hukum ini memastikan pengamanan dan penyediaan beragam keuntungan dari hutan dan mencegah perambahan. Komponen keamanan sosial pengelolaan hutan kemasyarakatan kemudian dapat menjadi signifikan (Arnold 2001).

\section{Ambondiaa}

Ambondiaa didirikan pada 1900-an oleh suku Tolaki. Sagu dan padi ladang merupakan tanaman utama dan makanan pokok bagi masyarakat (Gambar 8). Pada 1950-an hingga 1960-an, gerakan separatis memaksa masyarakat setempat untuk pindah ke Unaaha. 


\section{Ambondiaa, 2012}

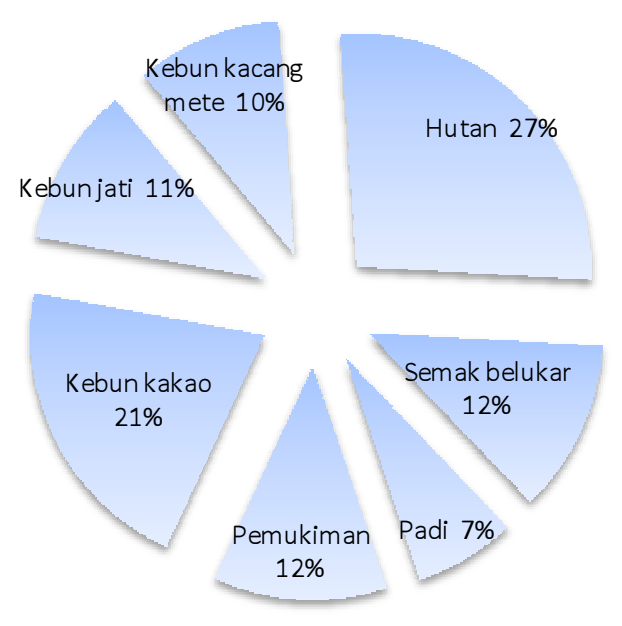

Gambar 8. Penggunaan lahan terkini di Desa Ambondiaa berdasarkan perspektif masyarakat

Pada 1980-an, para petani mulai menanam kakao dengan bibit berasal dari Kolaka Utara. Kemudian jumlah kebun kakao mulai meningkat. Pemerintah, lewat Badan Pertanaman, juga menyediakan

1000 bibit kakao per rumah tangga pada 2000. Pada 1997, Desa Ambondiaa dimanfaatkan untuk mempersiapkan pemekaran desa Asinua Jaya. Pada saat itu para petani bergantung pada kakao, pemrosesan sagu, dan lada untuk menyokong mata pencaharian mereka. Sekarang ini, tutupan hutan dan kebun kakao skala kecil mendominasi di desa.

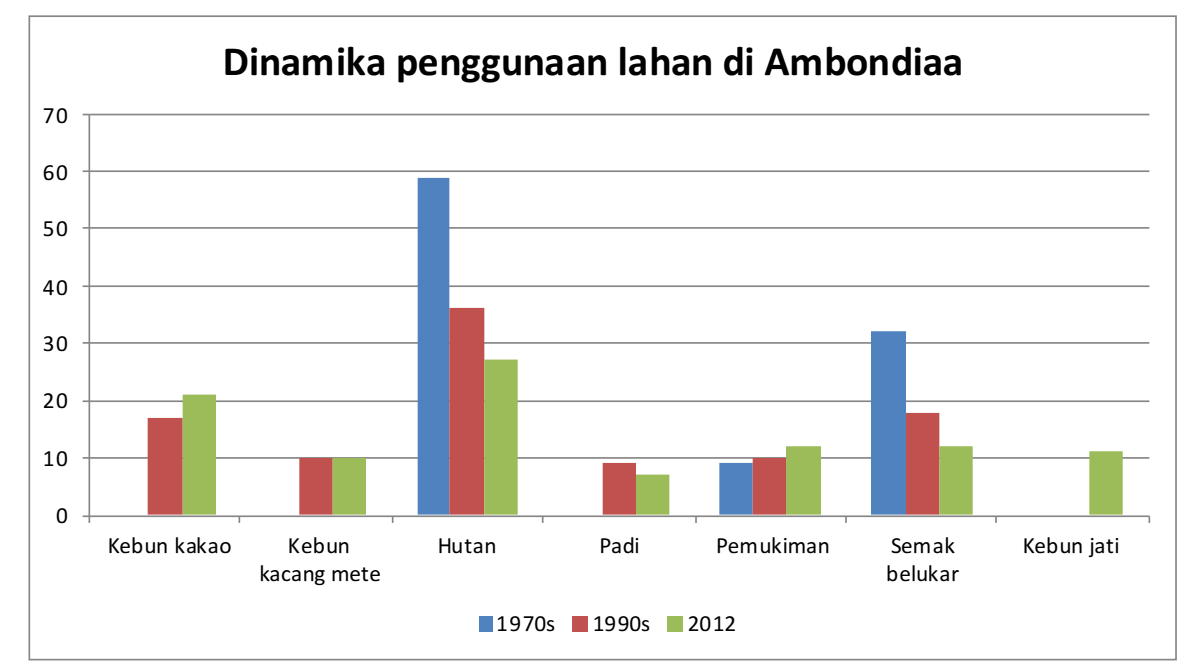

Gambar 9. Dinamika penggunaan lahan di Ambondiaa berdasarkan perspektif masyarakat

\section{Lamunde}

Lamunde didirikan sebelum 1940-an oleh suku Tolaki yang hidup dari ladang padi berpindah. Pada 1970-an dan 1980-an, beberapa pendatang dari Sulawesi Selatan dan Tana Toraja melakukan budi daya kakao dan cengkeh. Suku Tolaki mulai belajar cara menggunakan hewan ternak untuk 
membajak sawah. Petani setempat menghentikan ladang berpindah dan memulai budi daya padi dan menanam kakao.

Pada 1990 terjadi diversifikasi mata pencaharian masyarakat menjadi campuran padi, lada, cengkeh, rotan, dan madu. Pada tahun ini, harga cengkeh mencapai Rp 7000 per kilogram ${ }^{1}$. Penggunaan lahan belakangan ini didominasi oleh padi, konversi rawa menjadi budi daya padi dan agroforestri kakao (sebagai tanaman cash crop atau pendapatan utama di Lamunde).

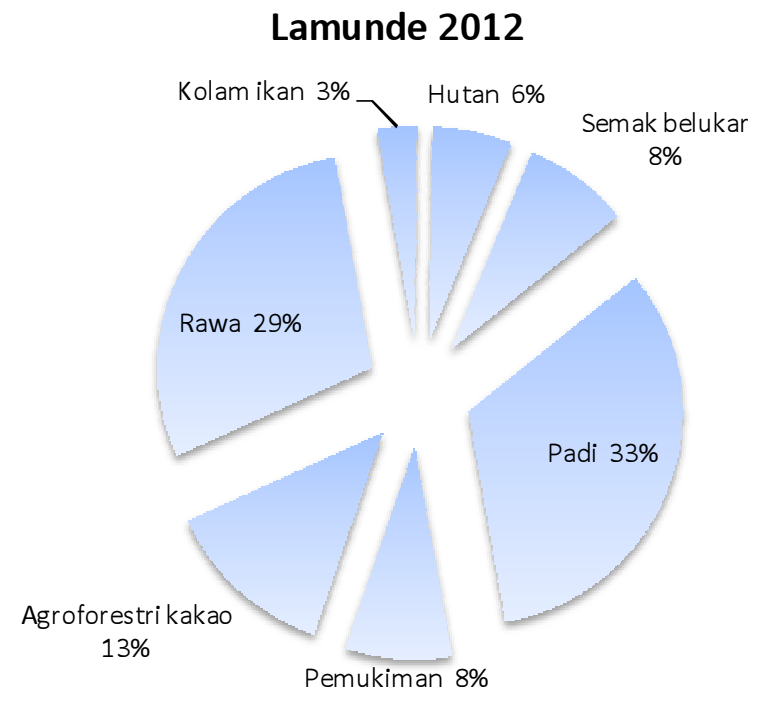

Gambar 10. Penggunaan lahan terkini di Desa Lamunde berdasarkan perspektif masyarakat

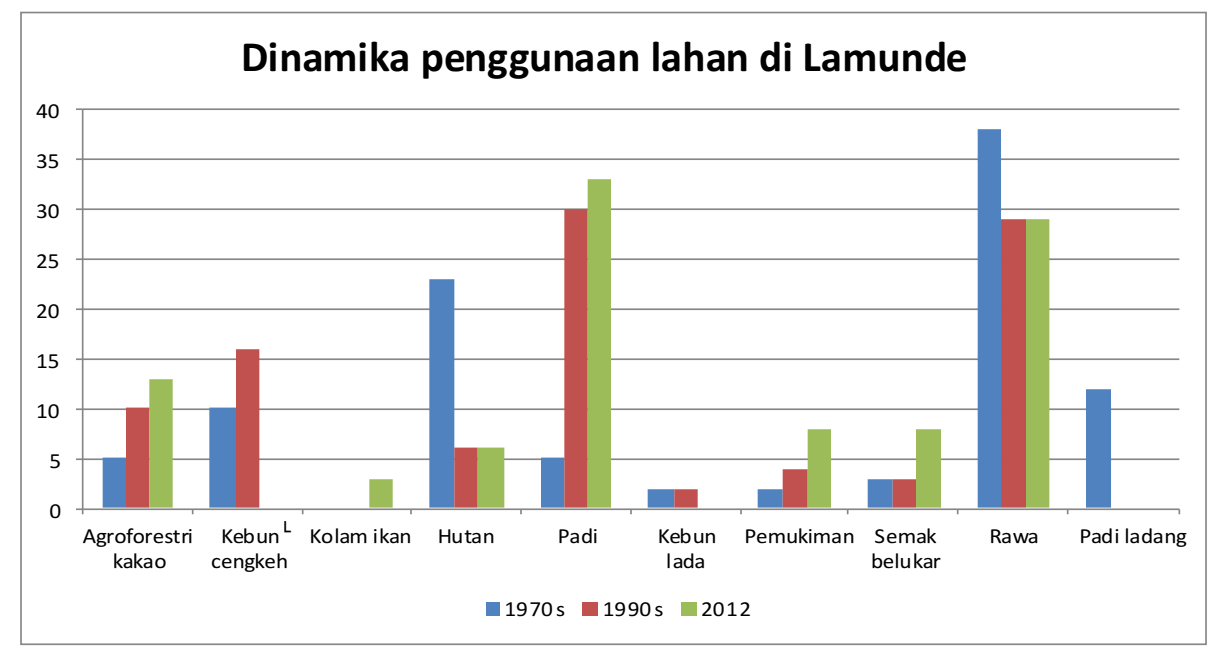

Gambar 11. Dinamika penggunaan lahan in Lamunde berdasarkan perspektif masyarakat

\section{Simbune}

Simbune didirikan pada 1930-an oleh suku Tolaki yang hidup dari ladang padi berpindah hingga akhir 1950-an. Pada 1970-an, mereka mulai menanam kopi dan cengkeh; pada 1993, Organisasi Kerjasama dan Pembangunan Ekonomi, Pemerintah Jepang, dan PT Hasfarm menyediakan bibit kakao F1 dalam

\footnotetext{
${ }^{1}$ US\$ $1,00=\operatorname{Rp} 9608$ (Desember 2012)
} 
program dukungan gabungan. Program ini juga menyediakan layanan penyuluhan dan dukungan produksi kepada para petani.

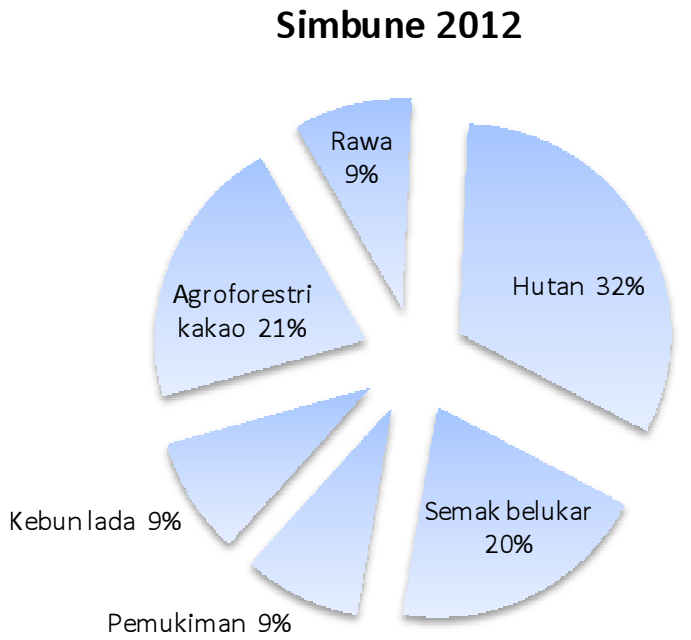

Gambar 12. Penggunaan lahan terkini di Desa Simbune berdasarkan persp ektif masyarakat

Pada 2009 program Gerakan Nasional Peningkatan Produksi dan Kualitas Kakao (Gernas) berfokus pada peremajaan budi daya kakao lewat pemupukan dan teknik sambung samping. Semua rumah tangga desa berpartisipasi dalam program Gernas yang menghasilkan 30 ha area peremajaan kakao, 19 ha dengan pemupukan, dan 25 ha dengan kegiatan sambung samping. Program ini masih berjalan. Lahan hutan masih mendominasi penggunaan lahan di desa ini dan kakao adalah tanaman perkebunan utama.

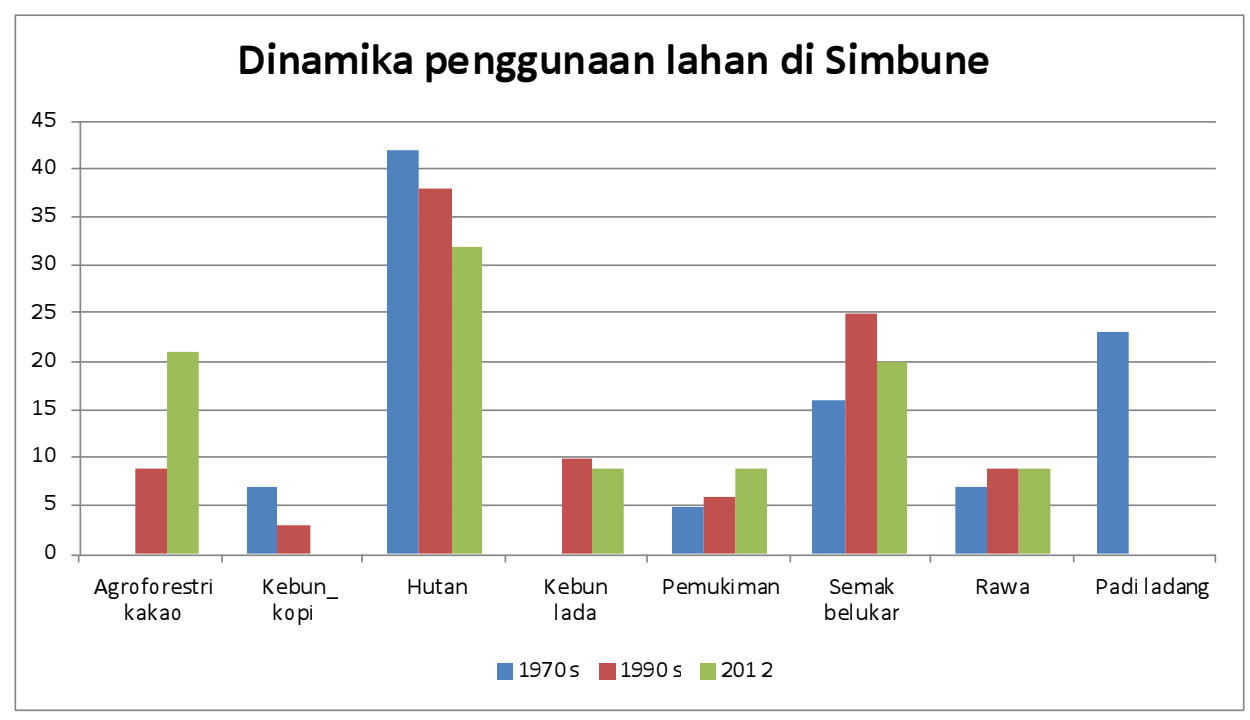

Gambar 13. Dinamika penggunaan lahan di Simbuneberdasarkan perspektif masyarakat

\section{Taosu}

Taosu didirikan pada 1990-an ketika suku Tolaki dari Aiure dan Rate-rate bermukim di area itu. Para penduduk hidup terutama dari ladang berpindah menggunakan padi, jagung, kopi, dan kelapa. Pada 1995 banyak petani mulai menanam kakao dan pada saat bersamaan PT Ladongi dan PT Hasfarm 
mendirikan pembibitan seluas 250 ha di Desa Poli Polia untuk mendukung program Gernas. Ladang berpindah berhenti dilakukan pada 1995 ketika banyak orang beralih menanam kakao dan lada.

Taosu, 2012

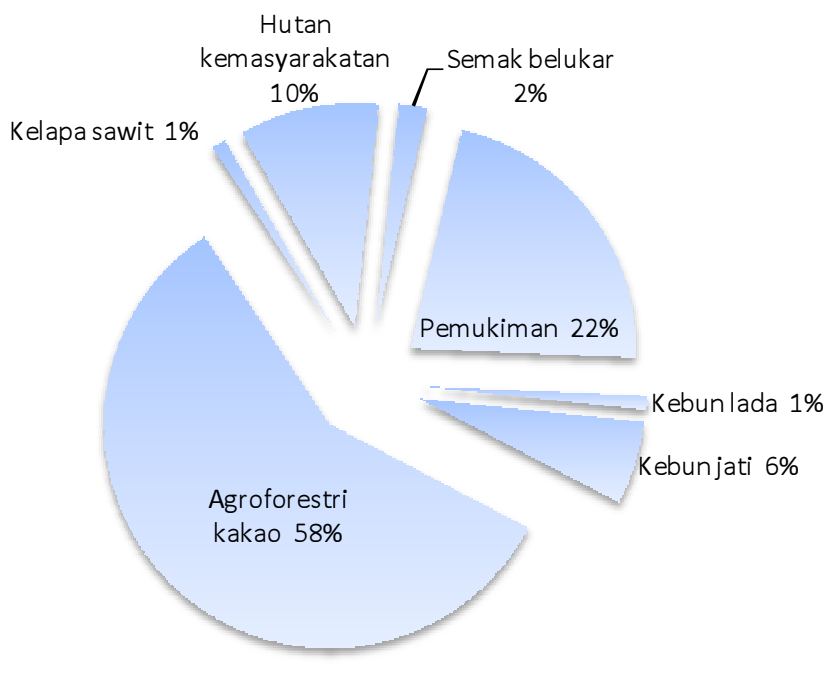

Gambar 14. Penggunaan lahan terkini di Desa Taosu berdasarkan perspektif masyarakat

Pada 1999, penduduk desa terlibat dalam pengukuran batas-batas hutan kemasyarakatan diikuti dengan pendirian pembibitan jati dan sengon. Pada 2000-an, mereka berpartisipasi dalam penanaman pohon kayu di hutan kemasyarakatan seluas 1000 ha di 4 desa. Belakangan ini, nilam sudah diintegrasikan dalam agroforestri kakao dan kebun jati, dan menjadi cukup populer. Namun, penggunaan lahan utama di Taosu didominasi oleh agroforestri kakao.

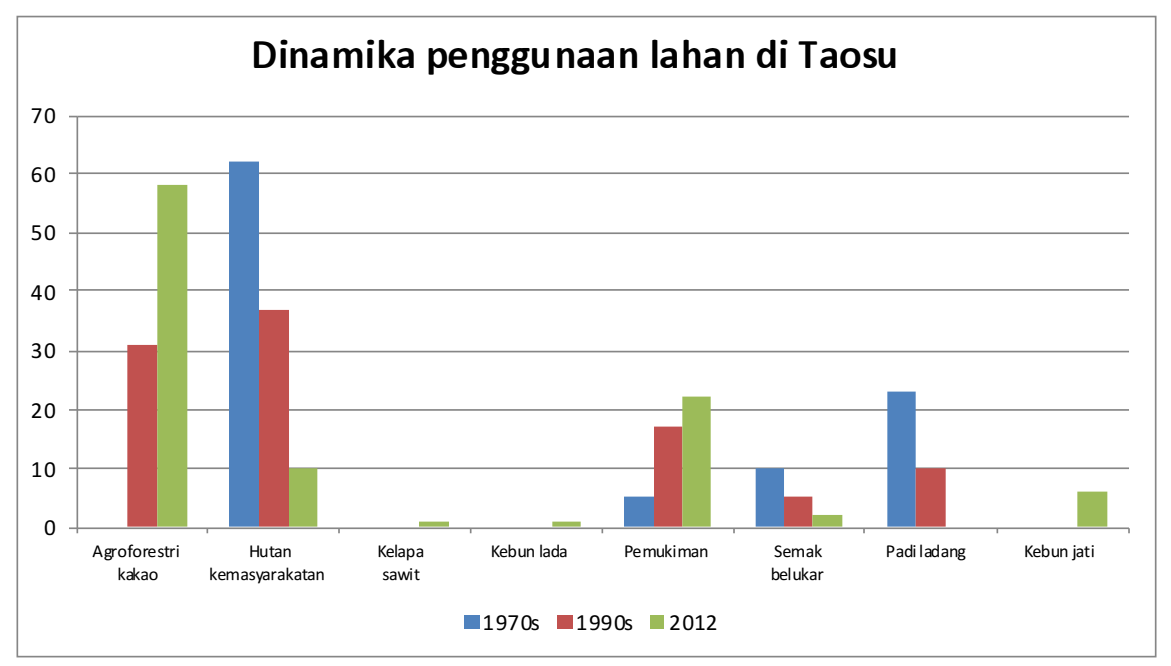

Gambar 15. Dinamika penggunaan lahan di Taosu berdasarkan perspektif masyarakat 


\section{Wonua Hoa}

Masyarakat suku Tolaki yang bermukim di desa ini sebelum kemerdekaan 1945 bergantung pada ladang berpindah, sayuran, kopi, dan sagu. Pada 1969 mereka memulai budi daya padi tetapi terbatas. Pada 1980-an masyarakat mulai menanam pohon jati dengan bibit yang berasal dari Dinas Kehutanan. Sebagian penduduk desa mencoba menanam kakao dan kacang mete. Jumlah ladang padi berkurang akibat konversi ladang menjadi sawah.

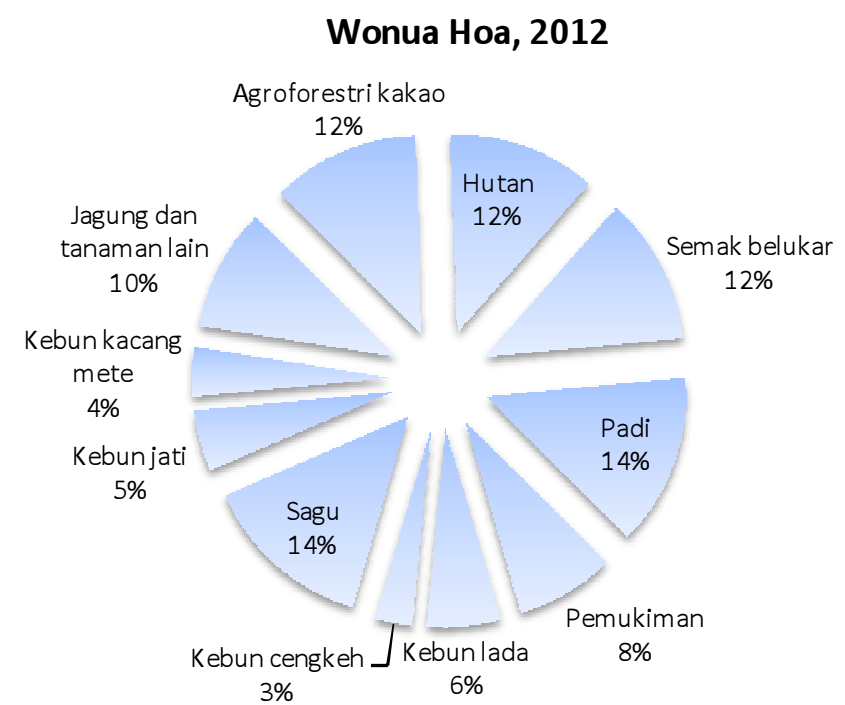

Gambar 16. Penggunaan lahan terkini di Desa Wonua Hoa berdasarkan perspektif masyarakat

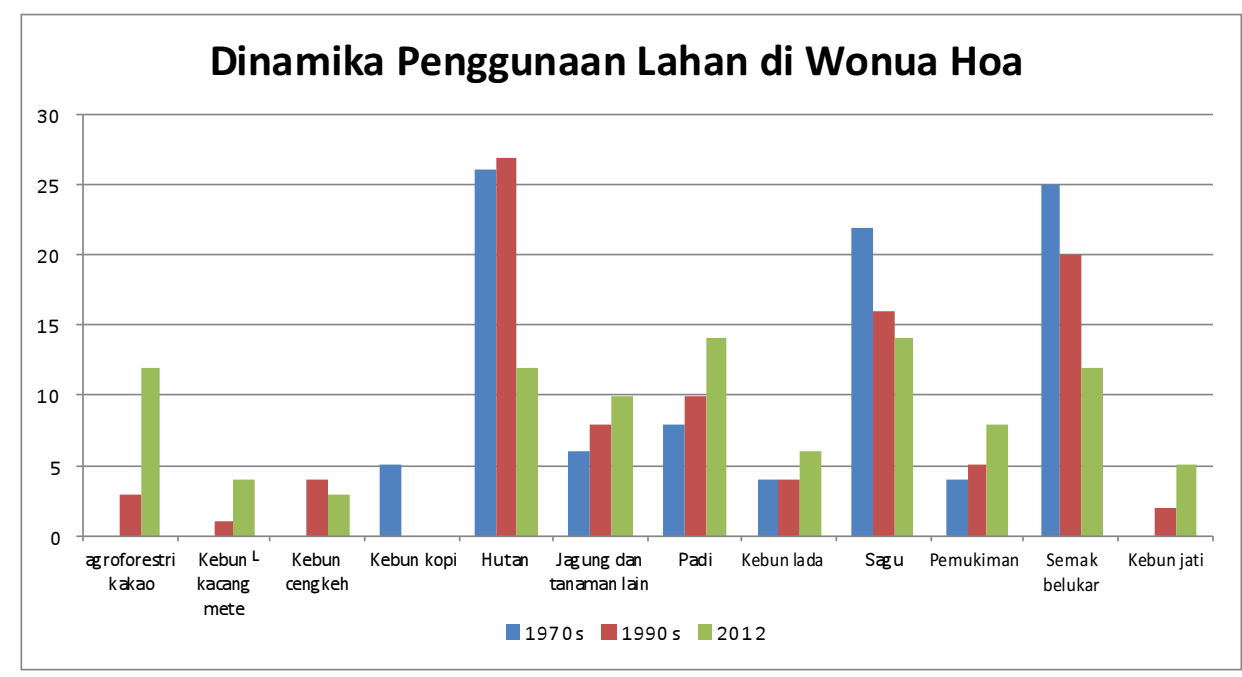

Gambar 17. Dinamika penggunaan lahan di Wonua Hoa berdasarkan perspektif masyarakat

Desa Wonua Hua terdiri dari 3 dusun. Pada 1990-an banyak migran dari Sulawesi Selatan mulai berdatangan, bergabung dengan masyarakat setempat tinggal di dusun I dan II. Pada 2000-an jumlah pendatang dari Sulawesi Selatan yang meningkat (34 keluarga) bermukim secara permanen di dusun III yang dinamai Lalobite untuk menanam kakao dan lada. Kebanyakan masyarakat lokal di dusun I dan II menanam padi, kakao, lada, dan nilam dalam sistem kebun campur. Pada 2010 Dinas Pertanian 
Sulawesi Tenggara memberikan pelatihan sambung samping. Program Gerakan Rehabilitasi Hutan Nasional (Gerhan) juga menyediakan 45000 bibit jati dan 10000 bibit sengon.

\subsubsection{Tipologi 2 (desa lokal dan pendatang)}

Tipologi ini terdiri dari penduduk desa asli suku Tolaki dan pendatang (kebanyakan suku Bugis dan sedikit suku Jawa).

\section{Anggawo}

Anggawo didirikan pada masa kolonial Belanda (sebelum 1945). Suku asli Tolaki mempraktikkan ladang berpindah dengan padi, kelapa, jagung, dan sagu. Para penduduk lebih mengenal dengan budi daya jati setelah 1955. Pada 1990-an ketertarikan masyarakat untuk menanam kakao mulai muncul dan para penduduk desa mulai membeli bibit kakao dari Kolaka.

\section{Anggawo, 2012}

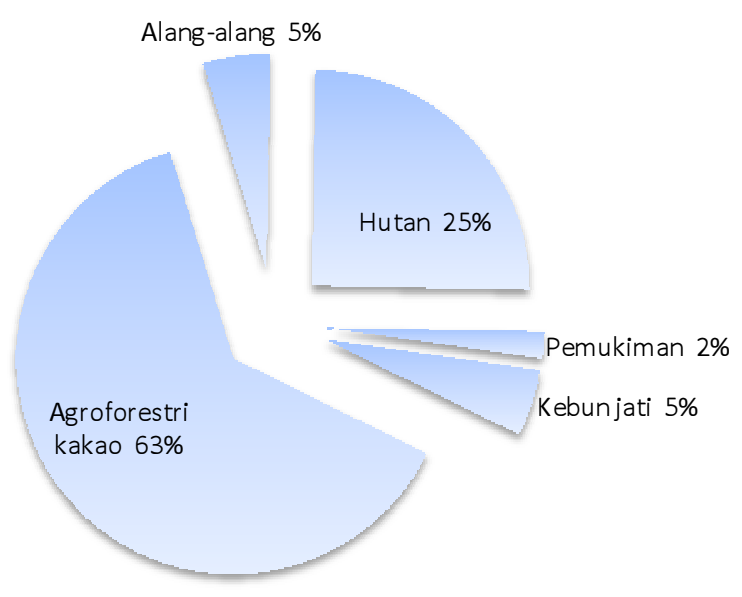

Gambar 18. Penggunaan lahan terkini di Desa Anggawo berdasarkan perspektif masyarakat

Pada 2000 bibit kakao disuplai melalui proyek pemerintah. Masyarakat setempat yang memiliki tanah seluas 0,5 ha menerima pupuk, herbisida (Tamaris), dan 1000 benih kakao atau 450 bibit kakao. Pada tahun yang sama, para penyuluh menyarankan pemberian jarak tanam $3 \times 3 \mathrm{~m}$. Pada tahun itu juga, para pendatang Jawa dan Bugis tiba dari Pulau Jawa dan Sulawesi Selatan untuk bermukim dan menanam kakao di desa ini.

Sekarang ini, penggunaan lahan yang mendominasi adalah agroforestri kakao dan tutupan hutan. Kakao ditanam tumpangsari dengan lada, jeruk, durian, nanas, rumput gajah (Pennisetum purpureum), dan jagung. 


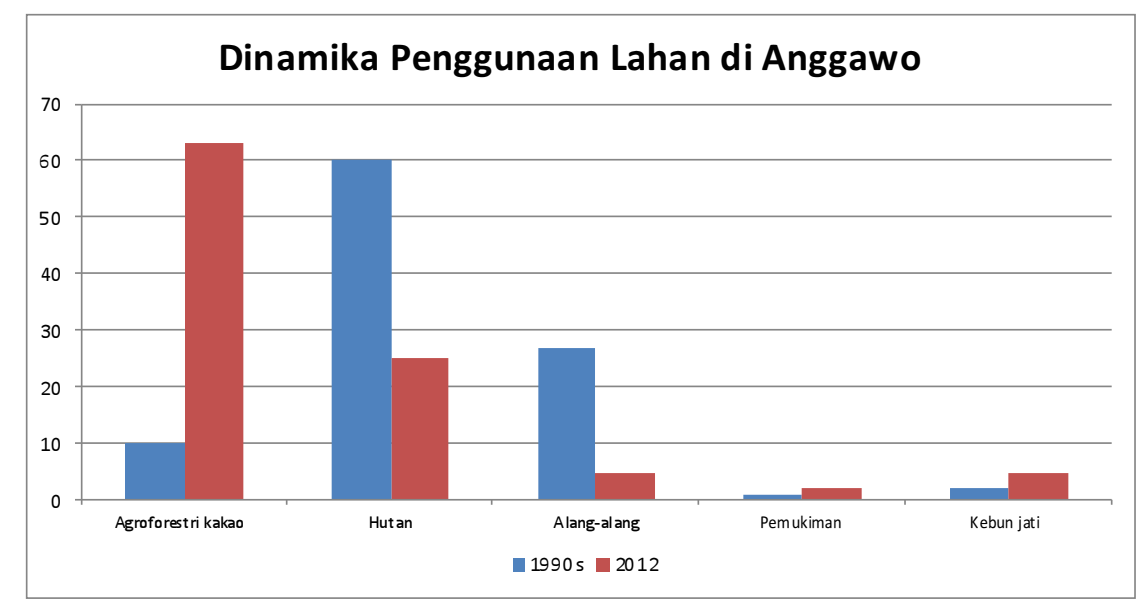

Gambar 19. Dinamika penggunaan lahan di Anggawo berdasarkan perspektif masyarakat

\section{Lawonua}

Desa ini muncul pada 1930-an, ketika masyarakat masih bermukim di pinggrian Sungai Konawe-Eha dan menanam jagung dan tanaman lain untuk memenuhi kebutuhan sehari-hari. Rumah tangga pertama berasal dari suku Tolaki dari Desa Amosilu; kemudian suku Bugis pendatang tiba dari Bone dan menjadi mitra lokal. Masyarakat desa ini secara bertahap membuka hutan untuk ladang berpindah yang dipakai menanam padi, kopi lokal, sagu, kelapa, dan jagung.

Pada 1959 bantaran Sungai Konawe-Eha jebol setelah terjadi hujan deras dan menimbulkan dampak sangat buruk pada desa-desa sepanjang tepian sungai. Pada 1978, pemerintah (walaupun sedikit terlambat) memberikan bantuan untuk yang tertimpa musibah, mencakup rumah berukuran 4 x $6 \mathrm{~m}$ di daerah bebas banjir dan biaya kebutuhan dan perlengkapan hidup selama setahun.

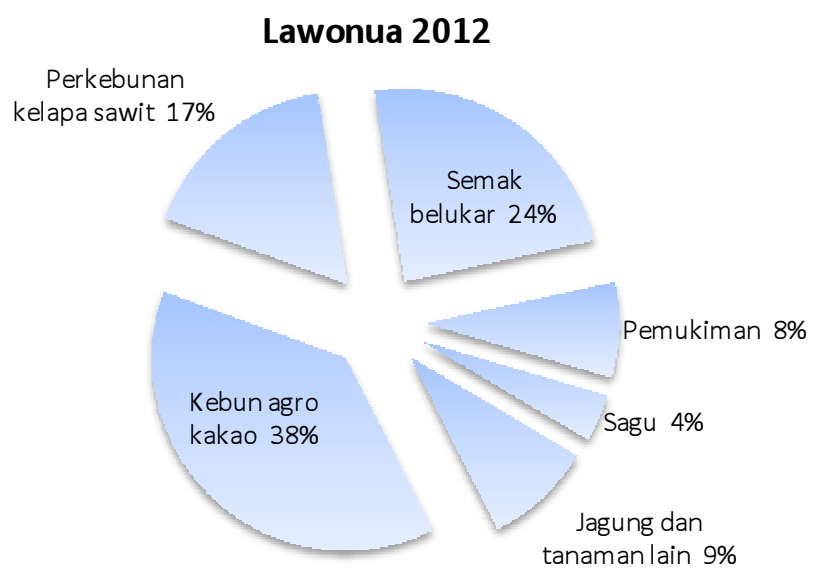

Gambar 20. Penggunaan lahan terkini di Desa Lawonua berdasarkan perspektif masyarakat

Pada awal 1980-an masyarakat belum mengenal kakao, tetapi pada 1987 mereka mulai menanam kakao dengan bibit dari Sumatra Selatan yang disediakan oleh pemerintah. Pada 1990-an, banyak pendatang dari Sinjai, Sopeng, Bulukumba, juga masyarakat dari desa-desa di sekitar Lawonua datang dan bermukim di desa ini. Kelompok pendatang lain dari Sulawesi Selatan (Wajo, Sopeng, dan Sinjai) 
juga datang dan menanam kakao pada 1997. Dari 1999-2000, penduduk desa mendapatkan 1200 bibit kakao per hektar, juga bibit rambutan dan durian, pupuk, perlengkapan pertanian, dan herbisida/pestisida melalui Proyek Pembangunan Pertanian Regional Selatan (Southern Regional Agricultural Development Project-SRADP). Badan pertanaman juga mendukung sekolah lapangan untuk petani pada 2004; topik-topik utamanya adalah pengelolaan hama dan cara peningkatan produksi. Tiga puluh orang berpartisipasi dalam program ini selama 6 bulan, dua kali seminggu.

Pada 2008, sekitar 100 rumah tangga sekali lagi menerima bibit jati (50 batang per rumah tangga) juga sukun, durian, rambutan, jeruk, dan cengkeh beserta sarana pertaniannya. Sekarang ini, kebanyakan orang menanam kakao, lada, rambutan, durian, dan jati. Perusahaan perkebunan kelapa sawit, PT Agrindo Utama Mas, juga mulai mendirikan 1000 ha kebun kelapa sawit di desa tersebut.

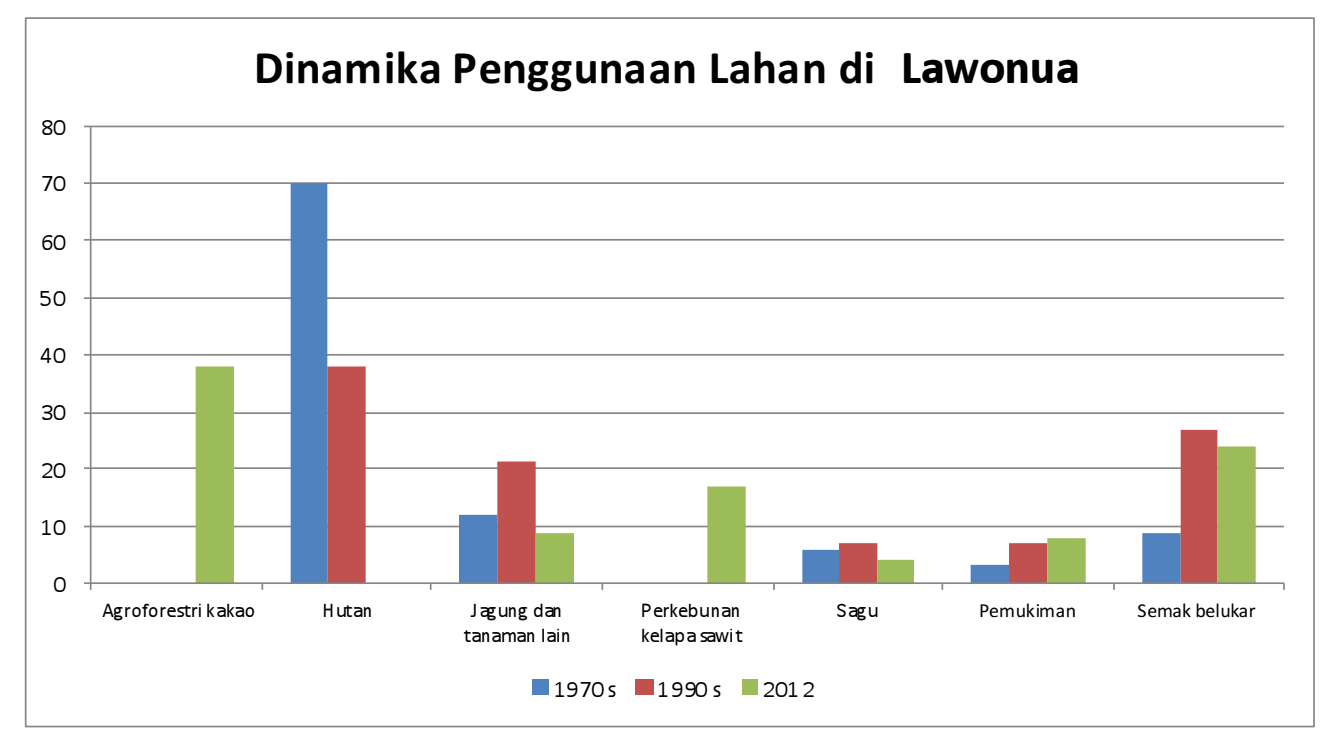

Gambar 21. Dinamika penggunaan lahan di Lawonua berdasarkan perspektif masyarakat

\subsubsection{Tipologi 3 (desa transmigran lama)}

Tipologi desa ini terdiri dari para transmigran yang kebanyakan berasal dari Bali dan Jawa. Mereka datang pada periode kejayaan program transmigrasi pada 1970-an.

\section{Tasahea}

Pada 1940, masyarakat yang sudah bermukim di sekitar Tasahea bergantung pada ladang berpindah sebagai mata pencaharian mereka. Populasi di area itu masih sedikit hingga 1960-an. Pada 1970-an, transmigran dari Bali dan Jawa mulai menempati area transmigran di Ladongi I dan Ladongi II. Beberapa warga itu bermukim di sekitar Tasahea, menerapkan ladang berpindah untuk memenuhi kebutuhan mereka dan mengumpulkan wikoro atau ubi untuk kebutuhan pangan. 


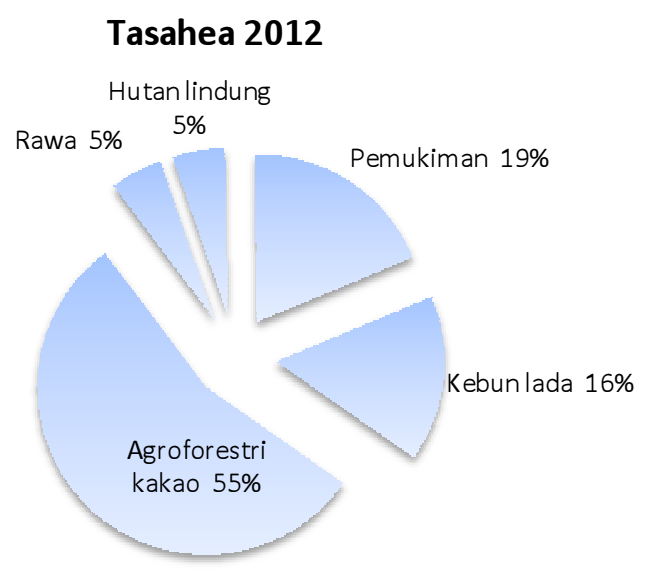

Gambar 22. Penggunaan lahan terkini di Tasahea berdasarkan perspektif masyarakat

Dari 1970 hingga 1975, masyarakat yang bermukim di sepanjang jalan utama mulai menanam cengkeh. Pada saat itu, Tasahea, Tababu, Benggi, dan Megaloma masih menjadi dusun yang terdiri dari 20 rumah tangga. Mereka melakukan budi daya sagu dan padi ladang. Pada 1986, pemerintah membantu tiap rumah tangga 200 bibit kakao. Pada 2000-an, banyak orang yang menanam kakao menggunakan bibit dari Kolaka Utara.

Hal ini berlanjut hingga 2008 ketika masyarakat menjadi tertarik pada lada; tetapi sayangnya, banyak tanaman lada mati akibat penyakit jamur. Pada saat yang sama, kebun kakao skala kecil diserang hama penggerek batang. Sekarang ini, agroforestri kakao dan kebun lada mendominasi lahan desa, namun saat ini agriforestri kakao dilanda penyakit busuk buah (Phytophthora palmivora),

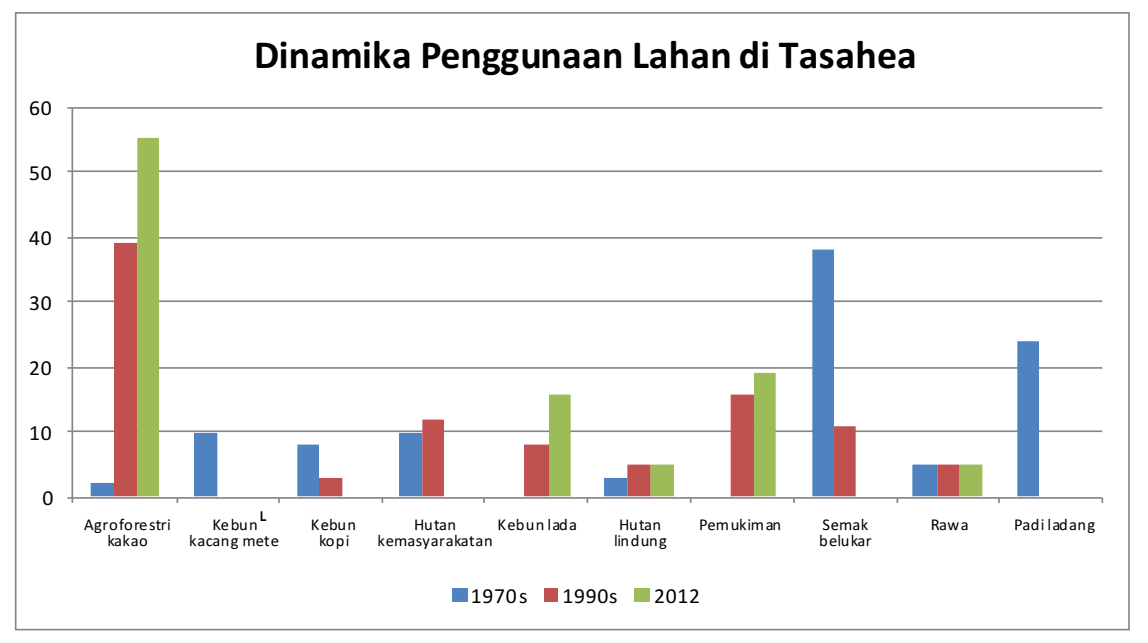

Gambar 23. Dinamika penggunaan lahan di Tasahea berdasarkan perspektif masyarakat

\subsubsection{Tipologi 4 (desa transmigran baru)}

Tipologi desa ini terdiri dari masyarakat pendatang yang berasal dari Sulawesi Selatan dan transmigran dari Nusa Tenggara Timur dan Jawa yang tinggal bersama dengan suku Tolaki setempat. 


\section{Lalobite}

Lalobite adalah bagian dari Desa Wonua Hoa yang didirikan lebih dari 10 tahun yang lalu oleh pendatang dari Bugis. Lalobite adalah salah satu dusun yang ada di Wonua Hoa. Pada 1998, Lalobite masih tertutupi hutan, tetapi setelah 2004 akuisisi lahan dilakukan oleh petani skala kecil. Sekarang ini, penggunaan lahan di Lalobite didominasi oleh hutan, agroforestri kakao, semak belukar, dan kebun cengkeh, sementara penggunaan lahan umum di Wonua Hoa ditandai dengan padi, sagu, dan agroforestri kakao.

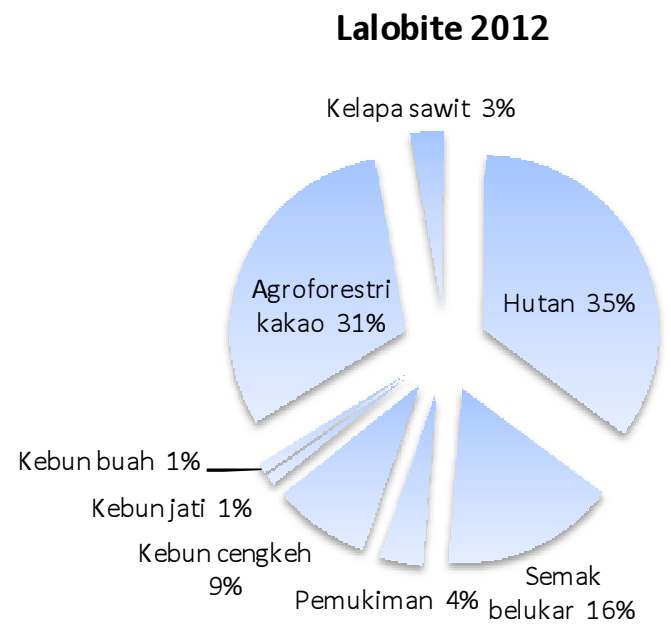

Gambar 24. Penggunaan lahan terkini di Lalobite berdasarkan perspektif masyarakat

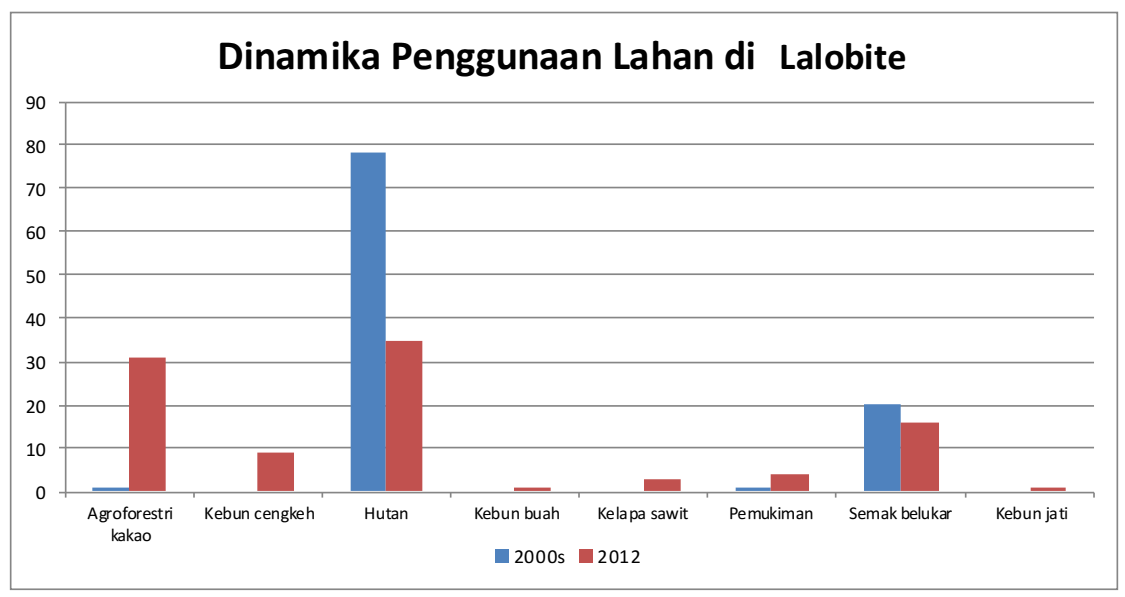

Gambar 25. Dinamika penggunaan lahan di Lalobite berdasarkan perspektif masyarakat

\section{UPT Asinua Jaya}

UPT Asinua Jaya baru saja didirikan sesuai dengan permintaan Desa Asinua Jaya untuk mempercepat proses pembangunan dan sebagai bagian dari strategi asimilasi ke dalam area ini. Desa UPT Asinua Jaya awalnya adalah padang rumput ketika diajukan sebagai lokasi transmigrasi pada 1982. Proposal itu direalisasikan pada 2007 ketika perumahan untuk para transmigran dibangun. Dua ratus keluarga 
pertama direlokasi pada 2008; 100 keluarga dari Nusa Tenggara Timur dan Jawa, dan 100 dari penduduk Asinua Jaya.

Pada tahun pertama, para transmigran diberi bantuan beras, minyak tanah, garam, dan alat pertanian ketika mereka mulai menggarap lahan. Sayangnya, banyak tanaman mereka yang mati karena musim kering berkelanjutan. Semua sumur di desa itu mengering dan air dari sungai menjadi alternatif terakhir.

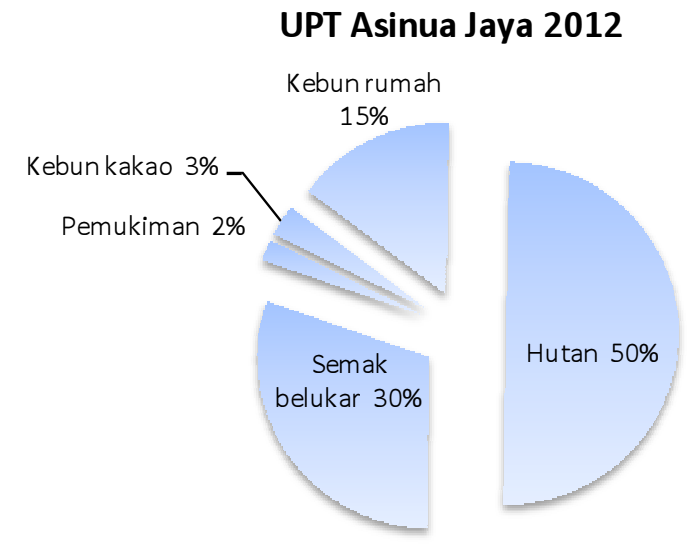

Gambar 26. Penggunaan lahan terkini di UPT Asinua Jaya berdasarkan perspektif masyarakat

Pada 2009, pemerintah mengusahakan untuk membuat pipa air di mata air Amate. Proposal untuk PLTA digulirkan pada 2010, tetapi masih belum direalisasikan. Akibat kondisi ini, banyak orang meninggalkan desa untuk mencari penghasilan di tambang emas di Bombana atau menjadi buruh upah (buruh harian) di perkebunan kelapa sawit di daerah Asera. Kesempatan mendapatkan mata pencaharian lainnya bagi masyarakat adalah pembalakan kayu, arang, lada, sagu, dan mengumpulkan madu. Setengah daerah desa masih ditutupi hutan dan semak belukar yang menyebar luas.

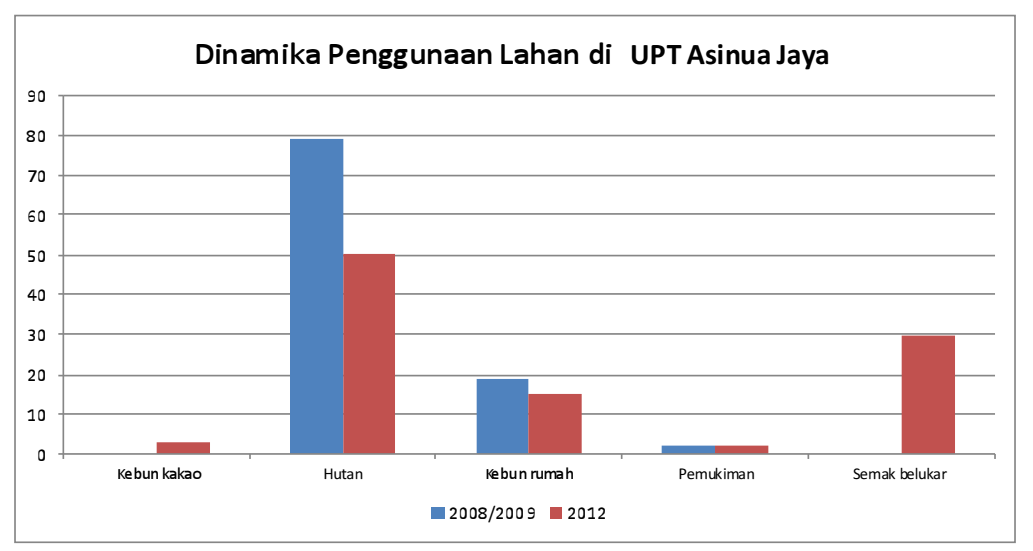

Gambar 27. Dinamika penggunaan lahan di UPT Asinua Jaya berdasarkan perspektif masyarakat 


\subsection{Perspektif rumah tangga mengenai karakteristik lahan dan penggunaan lahan}

\subsubsection{Karakteristik lahan di Sulawesi Tenggara}

\section{Aksesibilitas ke lahan}

\section{Lokasi lahan}

Lokasi lahan yang digarap dalam semua tipologi relatif sama (Gambar 28).

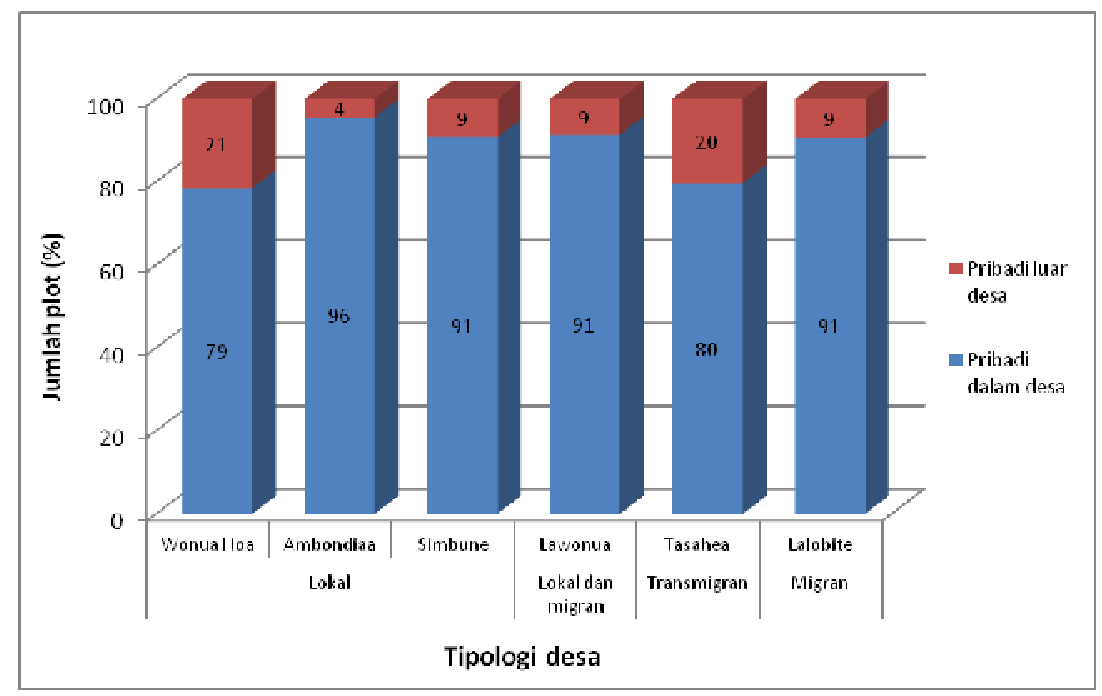

Gambar 28. Lokasi lahan di Sulawesi Tenggara

\section{Jarak dari rumah ke lahan petani dengan berjalan kaki}

Rata-rata waktu berjalan kaki dari rumah ke lokasi lahan pada Tipologi 1 lebih lama dibandingkan dengan desa-desa lain. Selain itu, semuanya relatif sama (Gambar 29).

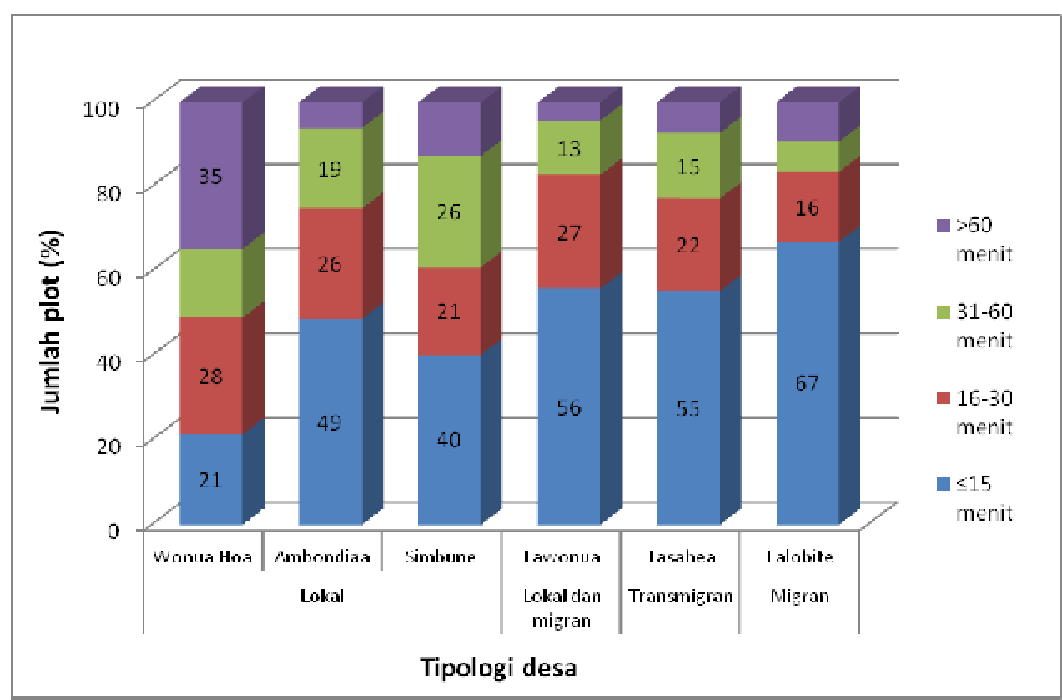

Gambar 29. Waktu berjalan kaki dari rumah menuju ke lahan di Sulawesi Tenggara 


\section{Permukaan lahan}

Setiap tipologi memiliki kondisi permukaan lahan yang berbeda-beda (Gambar 30).

Gambar 30 menunjukkan permukaan lahan di Sulawesi Tenggara. Pada Tipologi 1, lahan datar (59-74\%) atau miring (26-41\%). Pada Tipologi 2, ada lebih banyak lahan miring (72\%) walaupun lahan di beberapa daerah datar (28\%). Pada Tipologi 3 dan 4, permukaan lahan adalah datar (49\%) atau miring $(51 \%)$.

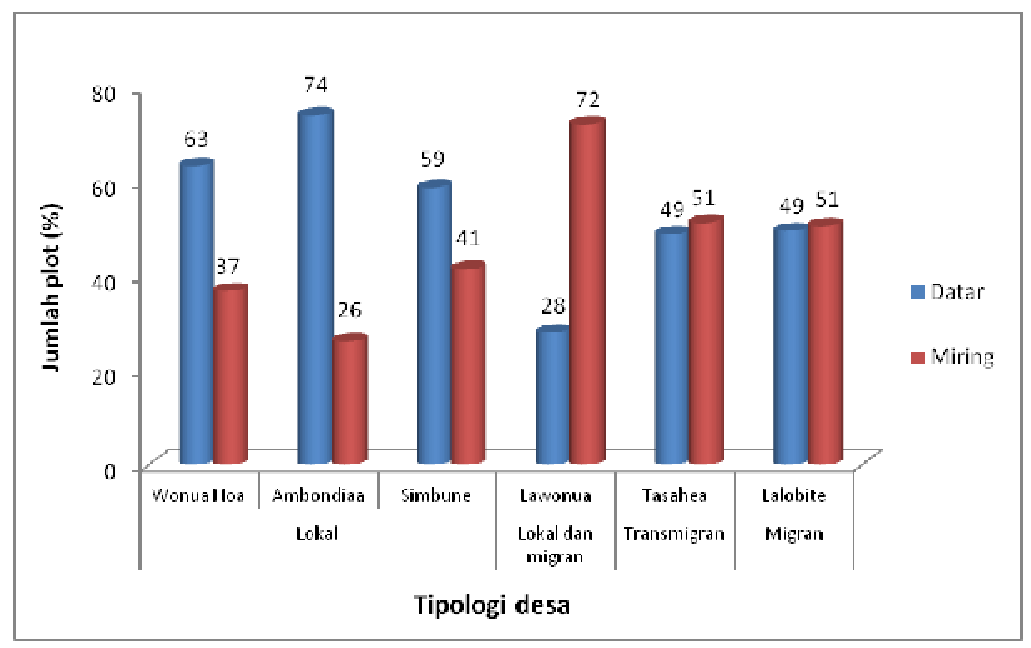

Gambar 30. Permukaan lahan di Sulawesi Tenggara

\section{Pengelolaan lahan saat ini}

Sebagian besar lahan dalam semua tipologi dimiliki dan digarap sendiri. Hanya ada sedikit persentase lahan yang tidak digarap (Gambar 31).

Gambar 32 mengindikasikan lahan di Sulawesi Tenggara sebagian besar didapatkan dengan cara warisan atau pembelian (Gambar 32). Pada Tipologi 1, lahan didapatkan dari warisan (66-70\%) atau pembelian (9-32\%). Pada Tipologi 2, lahan dibeli (59\%) atau diwariskan (33\%). Pada tipologi 3 , lahan didapatkan dari program pemerintah (62\%) dan lewat pembelian (37\%); pada Tipologi 4 , sebagian besar lahan dibeli (80\%).

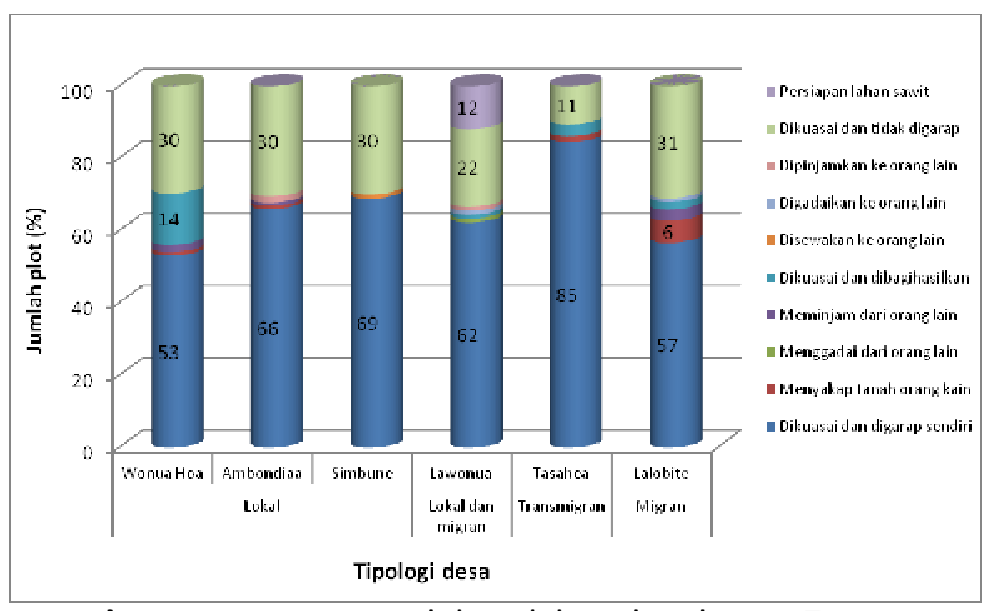

Gambar 31. Status pengelolaan lahan di Sulawesi Tenggara 


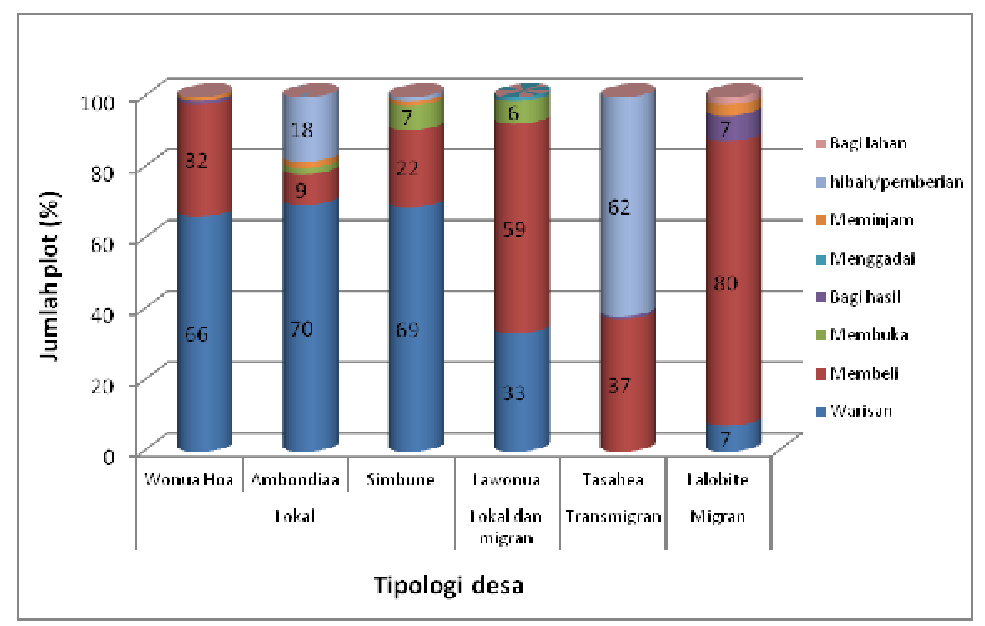

Gambar 32. Cara menguasai lahan di Sulawesi Tenggara

\section{Sumber lahan}

Gambar 33 mengilustrasikan sumber lahan para penduduk desa di semua tipologi. Ada perbedaan yang cukup jelas antara Tipologi 1, 2, dan 3 dengan para pendatang pada Tipologi 4 .

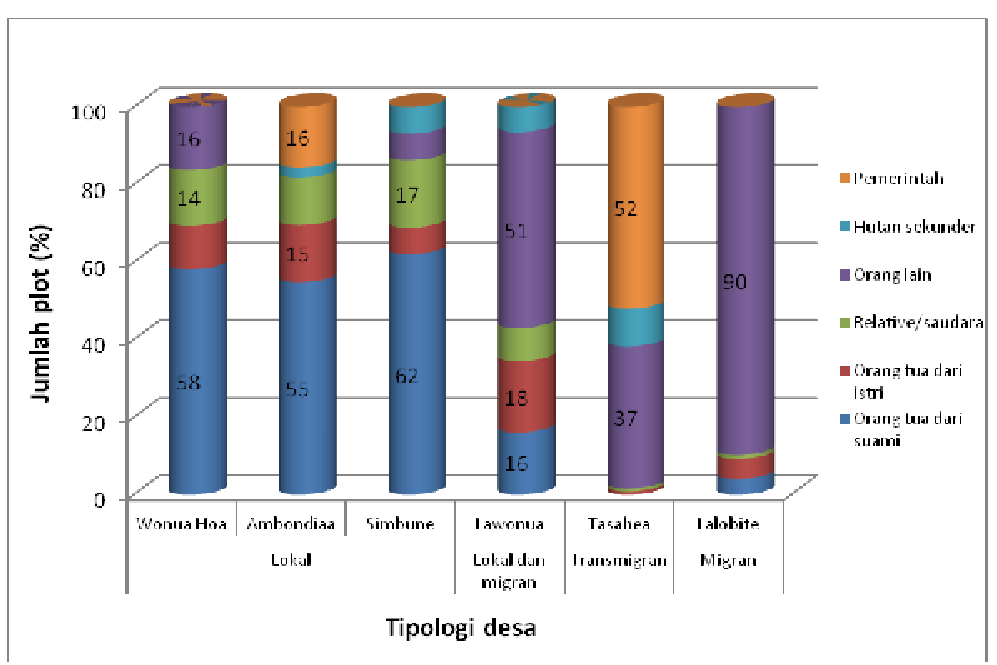

Gambar 33. Sumber lahan di Sulawesi Tenggara

\section{Tahun penguasaan lahan}

Distribusi kepemilikan lahan berdasarkan tahun penguasaan lahan berbeda pada keempat tipologi (Gambar 34), tetapi kebanyakan lahan pada Tipologi 1, 2, dan 4 didapatkan setelah 1990. Di desa transmigran (Tipologi 3) sejumlah besar lahan didapatkan sebelum 1980. 


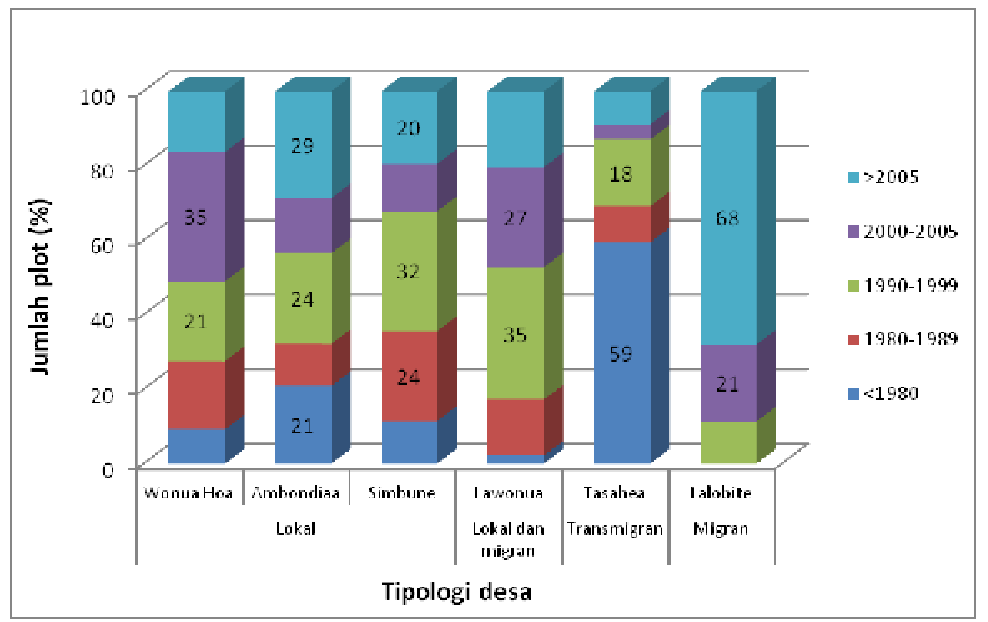

Gambar 34. Tahun penguasaan lahan di Sulawesi Tenggara

\subsubsection{Penggunaan lahan dan status kepemilikan lahan di Sulawesi Tenggara}

\section{Status kepemilikan lahan saat ini}

Status kepemilikan lahan saat ini antara Tipologi 1 dan 3 tipologi lain sangat berbeda; Tipologi 2, 3, dan 4 relatif sama (Gambar 35). Pada Tipologi 1, suami adalah pihak yang memiliki tanggung jawab paling besar. Pada tipologi lain, lahan dimiliki bersama.

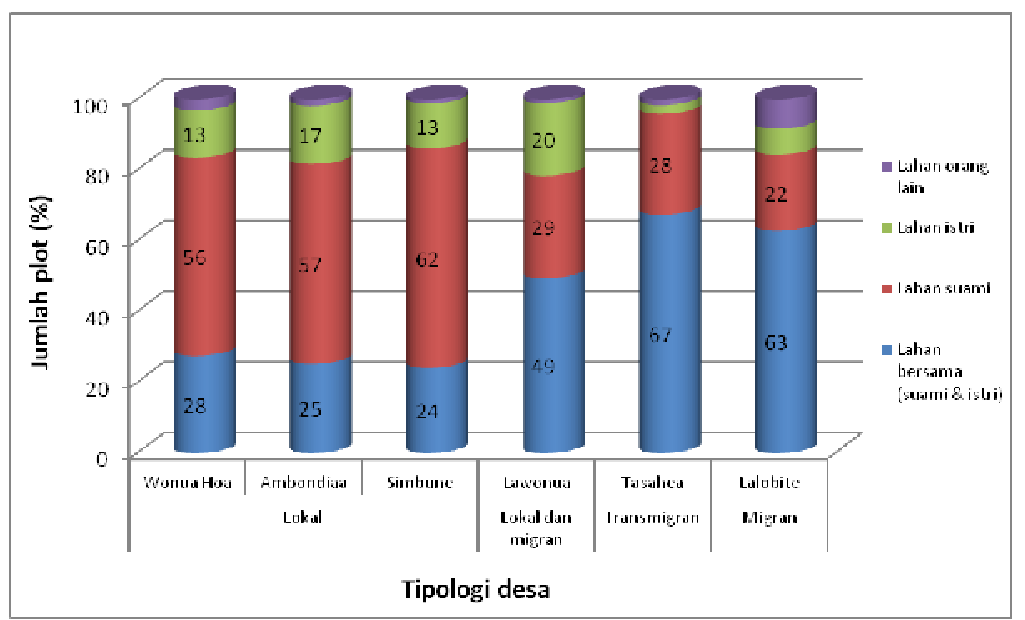

Gambar 35. Status kepemilikan lahan saat ini di Sulawesi Tenggara

\section{Penggunaan lahan sebelum saat ini}

Gambar 36 menjelaskan penggunaan lahan sebelum saat ini, sementara gambar 37 menjelaskan penggunaan lahan saat ini oleh para penduduk desa. Dulu semak belukar menjadi hal yang umum di semua tipologi kecuali Tipologi 3, yang memilih ladang sayur sebagai pilihan yang populer. 


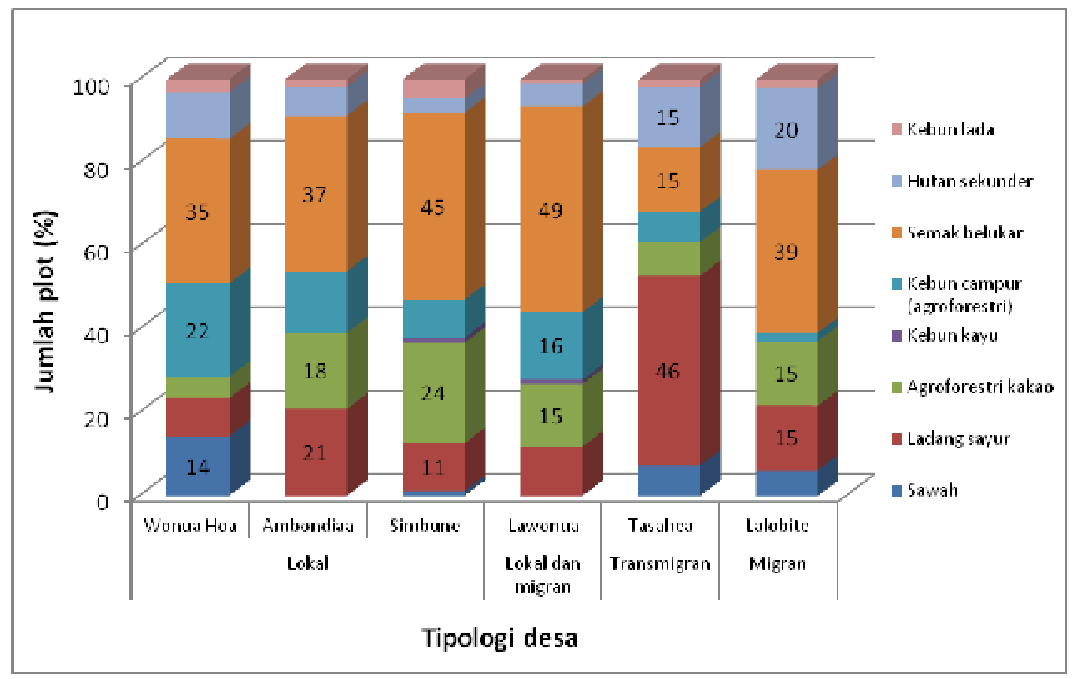

Gambar 36. Pola penggunaan lahan sebelum saat ini di Sulawesi Tenggara

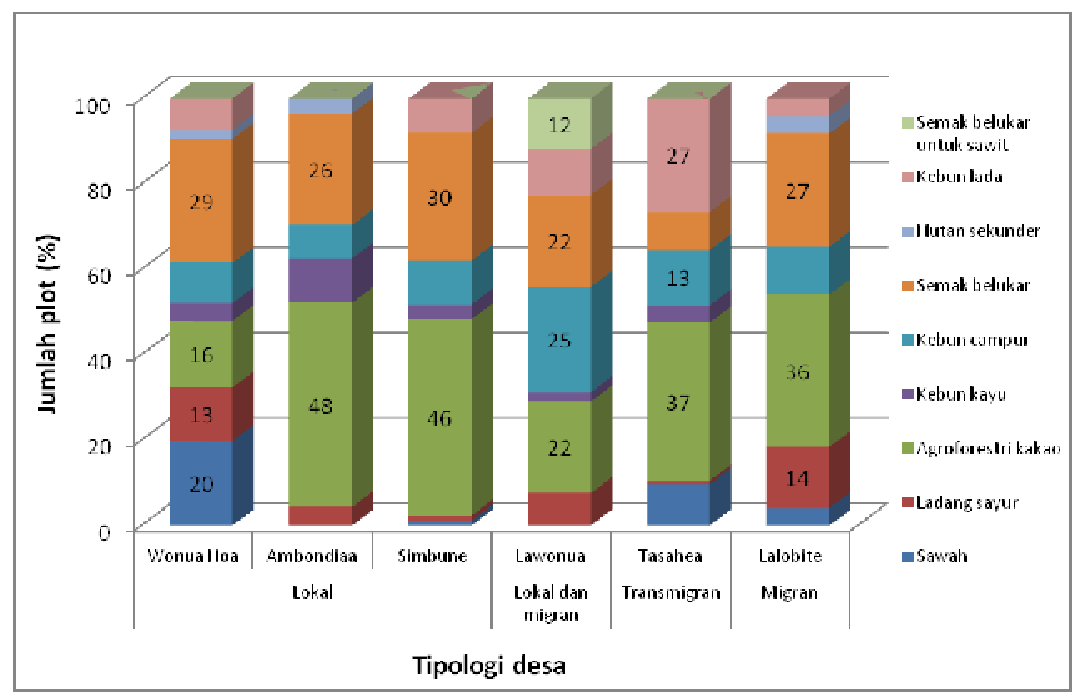

Gambar 37. Pola penggunaan lahan saat ini di Sulawesi Tenggara

Penggunaan lahan terkini oleh semua tipologi di Sulawesi Tenggara bersifat heterogen dan cukup kompleks seperti yang diilustrasikan dalam Gambar 37. Namun, selain di Wonua Hoa dan Lawonua, ada peningkatan dalam agroforestri kakao di desa-desa lain. Lahan semak belukar masih menjadi kendala umum di Tasahea, di mana hanya sedikit lahan yang termanfaatkan.

\section{Penggunaan lahan sebelum dan satu tahun setelah dikuasai}

Penggunaan lahan sebelum dan satu tahun setelah dikuasai di semua tipologi dijelaskan dengan detail dalam Gambar 38 dan 39. 


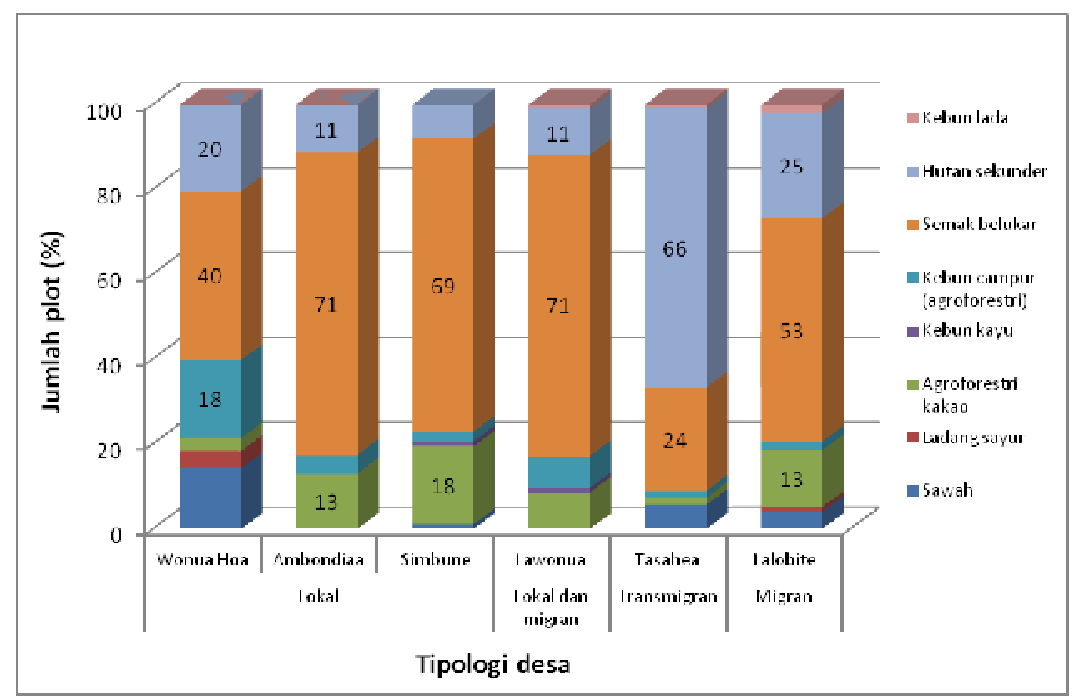

Gambar 38. Pola penggunaan lahan sebelum dikuasai di Sulawesi Tenggara

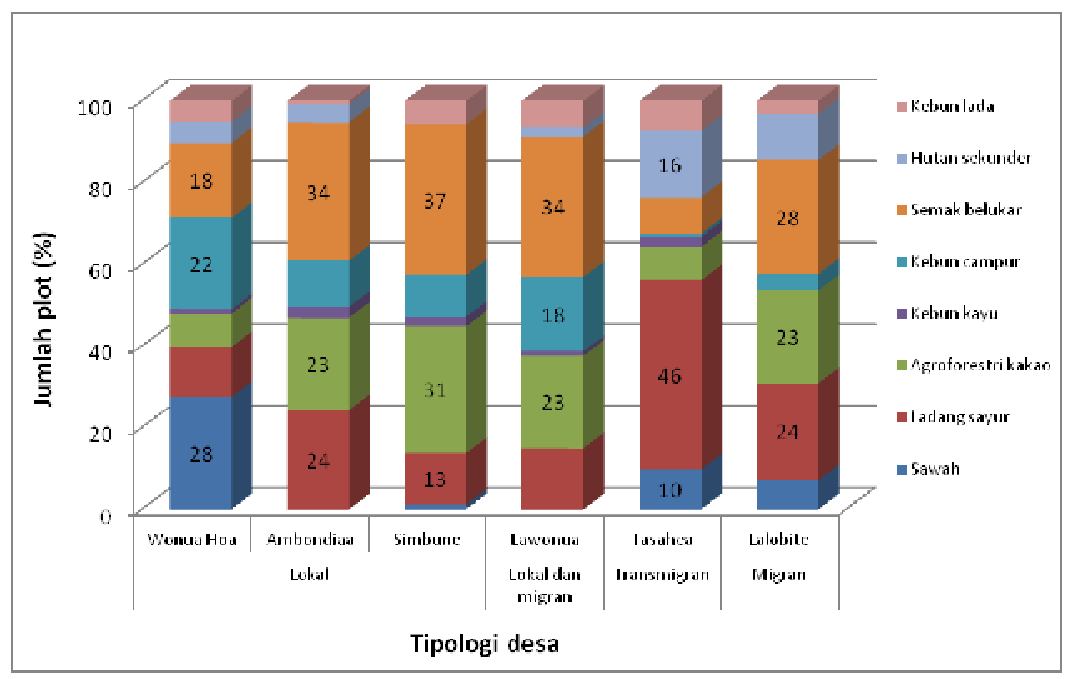

Gambar 39. Pola penggunaan lahan satu tahun setelah dikuasai di Sulawesi Tenggara

\section{Distribusi pohon dalam penggunaan lahan terkini}

Lima tipe jenis pohon ditanam para petani dalam kondisi yang berbeda-beda di tiap desa. Total ratarata pohon per hektar di Sulawesi Tenggara dirangkum dalam Tabel 4. Di Sulawesi Tenggara, semua kebun ditanami tanaman tahunan, tanaman multifungsi (multipurpose trees/MPTs) seperti buahbuahan, kayu, pisang, dan penaung (lain-lain). Berdasarkan jenis tanaman, tanaman tahunan (kakao dan kopi) mendominasi di semua desa. 
Tabel 4. Distribusi rata-rata jumlah tanaman per hektar di Sulawesi Tenggara

\begin{tabular}{|c|c|c|c|c|c|c|c|c|c|c|c|c|}
\hline \multirow{3}{*}{$\begin{array}{l}\text { Tipologi } \\
\text { desa }\end{array}$} & \multirow{3}{*}{ Desa } & \multirow{3}{*}{$n$} & \multicolumn{10}{|c|}{ Total rata-rata tanaman per hektar } \\
\hline & & & \multicolumn{2}{|c|}{$\begin{array}{l}\text { Tanaman } \\
\text { tahunan }\end{array}$} & \multicolumn{2}{|c|}{$\begin{array}{c}\text { Tanaman } \\
\text { multifungsi }\end{array}$} & \multicolumn{2}{|c|}{$\begin{array}{c}\text { Tanaman } \\
\text { kayu }\end{array}$} & \multicolumn{2}{|c|}{ Pisang } & \multicolumn{2}{|c|}{$\begin{array}{l}\text { Tanaman } \\
\text { penaung }\end{array}$} \\
\hline & & & $\mathrm{n}$ & $\%$ & $n$ & $\%$ & $n$ & $\%$ & $\mathrm{n}$ & $\%$ & $n$ & $\%$ \\
\hline \multirow{3}{*}{ Lokal } & Wonua Hoa & 1.072 & 643 & 60 & 49 & 5 & 108 & 10 & 6 & 1 & 266 & 25 \\
\hline & Ambondiaa & 1.156 & 737 & 64 & 83 & 7 & 172 & 15 & 25 & 2 & 140 & 12 \\
\hline & Simbune & 1.088 & 735 & 68 & 30 & 3 & 55 & 5 & 7 & 1 & 262 & 24 \\
\hline $\begin{array}{l}\text { Lokal dan } \\
\text { migran }\end{array}$ & Lawonua & 1.457 & 788 & 54 & 382 & 26 & 13 & 1 & 9 & 1 & 265 & 18 \\
\hline Transmigran & Tasahea & 1.090 & 642 & 59 & 75 & 7 & 46 & 4 & 7 & 1 & 319 & 29 \\
\hline Migran & Lalobite & 818 & 628 & 77 & 48 & 6 & 11 & 1 & 19 & 2 & 113 & 14 \\
\hline
\end{tabular}

\section{Opsi mata pencaharian masyarakat}

\subsection{Tipologi 1 (desa lokal)}

Kakao, padi, nilam, dan sagu merupakan tanaman dominan di Ambondiaa, Simbune, Lamunde, Taosu, dan Wonua Hoa. Namun, sistem pertanian tradisional yang digunakan menyebabkan produktivitasnya yang rendah.

\section{Kakao}

Kakao adalah tanaman dominan di Ambondiaa, Simbune, Lamunde, Taosu, dan Wonua Hoa. Semak belukar, hutan, dan ladang berpindah dikonversi menjadi kebun kakao karena kakao dianggap lebih menguntungkan. Pembukaan lahan digunakan dengan teknik tebas-tebang dan bakar. Penanaman kakao dimulai pada awal musim hujan tetapi para petani umumnya menanam sayur, jagung, semangka, dan tanaman jangka pendek sebelum menanam kakao. Jarak tanam diatur $3 \times 3 \mathrm{~m}$ dengan lubang tanam sedalam $15 \mathrm{~cm}$. Bibit kakao umumnya didapatkan dari kebun kakao yang ada di sekitar lahan para petani, berasal dari pohon sehat dengan tingkat produktivitas baik.

Kegiatan perawatan kakao meliputi penyiangan, pemupukan, dan pemangkasan juga pengendalian hama dan penyakit. Penyiangan dilakukan dua kali setahun sementara pemupukan dilakukan 2 atau 3 kali per tahun, atau bahkan tidak sama sekali, tergantung si petani. Pupuk urea, triple superphosphate (TSP), KCL, Phonska, nitrogen, fosfor, dan kalium (NPK) digunakan dengan beragam dosis, seperti 2-10 karung per pemupukan. Batang kakao dipangkas dua kali setahun, sementara pengendalian hama dan penyakit dilakukan dengan menyemprotkan pestisida dua kali sebulan sepanjang tahun, tergantung pada kondisi tanaman.

Kebun kakao di Taosu rata-rata berusia 15-20 tahun dan dapat memproduksi rata-rata 1 ton per hektar per tahun. Umumnya, para petani menjual hasil panen pada perantara di desa dengan harga Rp 15000 per kilogram (setelah 3 hari dikeringkan). 
Kendala dalam perkebunan kakao adalah:

- Hama dan penyakit, seperti penyakit busuk buah (Phytophthora palmivora), hama penggerek batang, kanker batang, buah busuk, dan jamur batang.

- Fluktuasi harga, kemungkinan dipengaruhi oleh perantara atau tengkulak

- Kurangnya teknologi pascapanen yang tepat

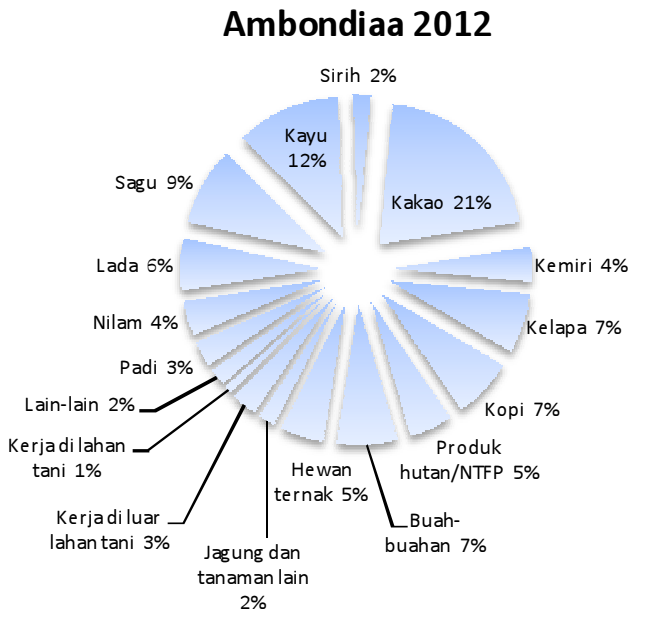

Simbune 2012

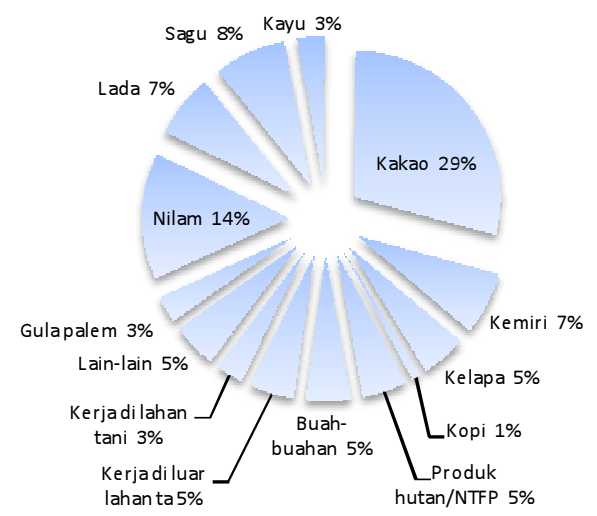

Wonua Hoa 2012

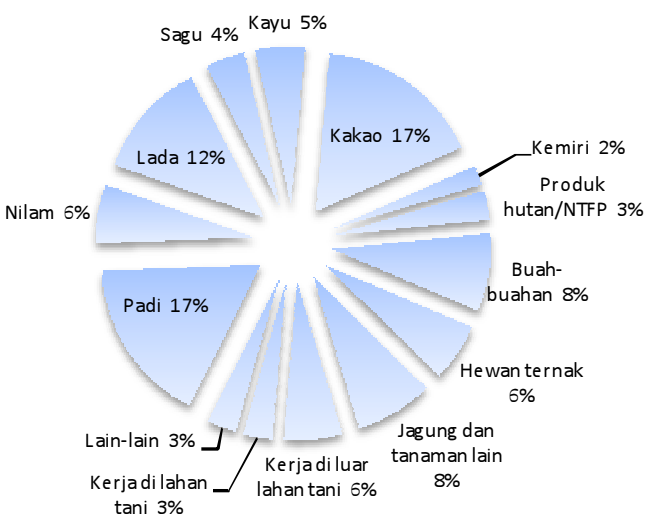

Lamunde 2012

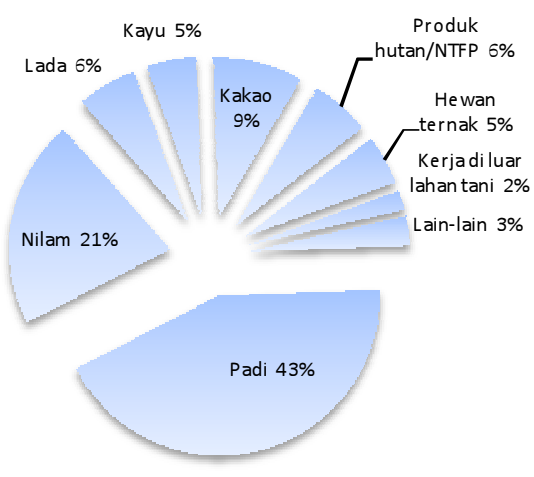

Taosu 2012

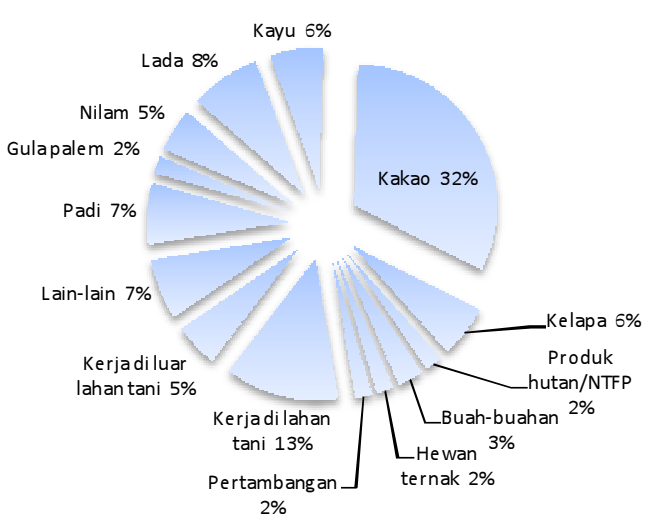

Gambar 40. Opsi mata pencaharian terkini di Ambondiaa, Lamunde, Simbune, Taosu, dan Wonua Hoa berdasarkan perspektif masyarakat 
Padi sawah adalah opsi mata pencaharian paling populer di Lamunde dan Wonua Hoa. Lahan sawah di desa ini mencakup 300 ha dengan rata-rata kepemilikan lahan 0,5 ha per rumah tangga. Varietas padi lokal dan hibrida yang ditanam adalah Elis, Mekongga, Luparin, Padi 66, Padi Kuda, Lampari, Konawe, Ciliwung, dan IR 36. Lahan digarap menggunakan traktor, terutama pada tanah yang cukup keras; dan menggunakan sistem olah tanah minimum di area rawa (hanya menyemprot gulma dengan herbisida sebelum penanaman). Penanaman dimulai pada Mei, biasanya dengan menyebarkan benih dengan tangan atau penyemaian langsung.

Teknik perawatan umum di Lamunde adalah:

- Penyiangan 13 kali selama satu musim---mencabut dengan tangan atau menyemprotkan herbisida pada minggu-minggu pertama sesudah penanaman

- Penyulaman padi dilakukan selama 10 hingga 30 hari sesudah penanaman. Proses penyulaman biasanya menggunakan padi muda yang berusia sama

- Pemupukan dua kali dalam semusim, ketika padi berusia 1 atau 2 bulan. Pupuk urea, TSP, NPK, SP36, dan Za digunakan dengan komposisi 1:2 urea dan TSP, 3 karung pupuk campuran untuk sekali pemupukan atau bergantung pada tingkat kesuburan tanah

- Pengendalian hama dilakukan 3 kali dalam semusim untuk mencegah serangan walang sangit (Leptocorisa oratorius), tikus, dan keong mas

Panen dilakukan ketika padi berumur 120 hari. Produksi mencapai sekitar 40-70 karung padi segar (1 karung setara dengan $100 \mathrm{~kg}$ ) dan pemanenan seringkali dilakukan oleh kelompok secara bersama (pasangki). Kebanyakan petani memanfaatkan padi untuk konsumsi pribadi; hanya sedikit disimpan untuk dijual di pasar. Sekarang ini, harga sekarung beras $(50 \mathrm{~kg}$ ) adalah sekitar Rp 350000 atau Rp 7000 per kilogram beras.

Kendala utamanya adalah: 1) hama seperti tikus, babi hutan, dan sapi yang merumput; 2) modal yang diperlukan cukup banyak; 3) kurangnya dukungan penyuluhan; dan 4) kurangnya air.

\section{Nilam}

Nilam cukup populer di kalangan masyarakat, terutama di Lamunde. Bibit nilam didapatkan baik dari dalam desa, maupun luar desa seperti Desa Ambopai kecamatan Tonondo, dan bahkan dari Kabupaten Kolaka Utara. Para petani melakukan tanam tumpangsari antara nilam dengan kakao atau pohon kayu, dengan jarak tanam 3 × $3 \mathrm{~m}$ untuk kakao dan 50 x $50 \mathrm{~cm}$ untuk nilam.

Penanaman nilam dilakukan langsung dengan menanam pucuk di lahan dan mencapai sekitar 500 tunas dalam sehari. Pupuk cair digunakan untuk mempercepat pertunasan.

Panen nilam dapat dilakukan hingga 3 kali dalam sekali tanam:

- Panen pertama pada 6 bulan setelah tanam

- Panen kedua pada 4 bulan berikutnya setelah panen pertama

- Panen ketiga tergantung pada kondisi tanaman 
Panen pertama 400 pohon nilam dapat memproduksi $125 \mathrm{~kg}$ nilam segar, menghasilkan Rp 3000 per kilogram. Produk ini dipasarkan di desa setelah semua daun dan batang kering dipotong-potong dan dijemur matahari selama 2 hari. Kendala utamanya adalah harga yang rendah, metode perawatan yang rumit, dan isu pemasaran.

\section{Sagu}

Pohon sagu umum ditemukan di Ambondiaa, kebanyakan diwariskan dan dimiliki oleh keluarga. Panen sagu dilakukan dengan cara menebang pohon berusia 7 tahun. Kemudian tebangan pohon dipotong-potong menjadi bagian kecil dan pati sagu dikeluarkan dengan bantuan alat parut. Panen dilakukan berkelompok, terdiri dari 3 sampai 4 orang yang dapat memproses 1 pohon per hari. Tidak ada panen pada musim hujan karena kondisi air yang keruh dapat menghasilkan "sagu hitam."

Satu pohon sagu dapat memproduksi sekitar 25 karung yang dijual Rp 40000 per karung (1 karung setara dengan $20 \mathrm{~kg}$ ). Pohon sagu dapat dijual secara langsung kepada pembeli dengan harga Rp 75000 per batang. Pati sagu terutama digunakan untuk konsumsi pribadi tetapi sebagian hasil produksi dijual ke pasar di Unaaha. Sekarang ini, pohon sagu berkurang akibat adanya eksploitasi berlebihan.

\subsection{Tipologi 2 (desa lokal dan pendatang)}

Kakao, padi, dan buah-buahan adalah tanaman dominan pada tipologi ini. Di desa-desa ini, sistem tradisional digabungkan dengan praktik inovatif yang diperkenalkan oleh pendatang Bugis dan Jawa. Hal ini menghasilan produktivitas yang lebih tinggi di daerah itu.

\section{Kakao}

Para petani menerapkan ladang berpindah pada fase pembukaan lahan untuk kebun kakao, biasanya dari September hingga Desember. Penanaman dilakukan pada awal musim hujan, pada Januari dan Februari. Umumnya, para petani menanam kakao segera setelah lahannya siap, tetapi beberapa petani juga melakukan budi daya sayuran sebelum menanam kakao. Pengaturan jarak tanam kakao adalah $3,5 \times 3,5 \mathrm{~m}, 3 \times 3 \mathrm{~m}, 3 \times 4 \mathrm{~m}$, atau $2 \times 4 \mathrm{~m}$. Para petani mendapatkan bibit kakao lokal terbaik dari pohon induk yang sehat dan produktif. Beberapa pohon kakao ini adalah turunan dari bibit F2 yang diambil dari proyek Pengembangan Usaha Tani Lahan Kering Sulawesi (PUTLKS). 

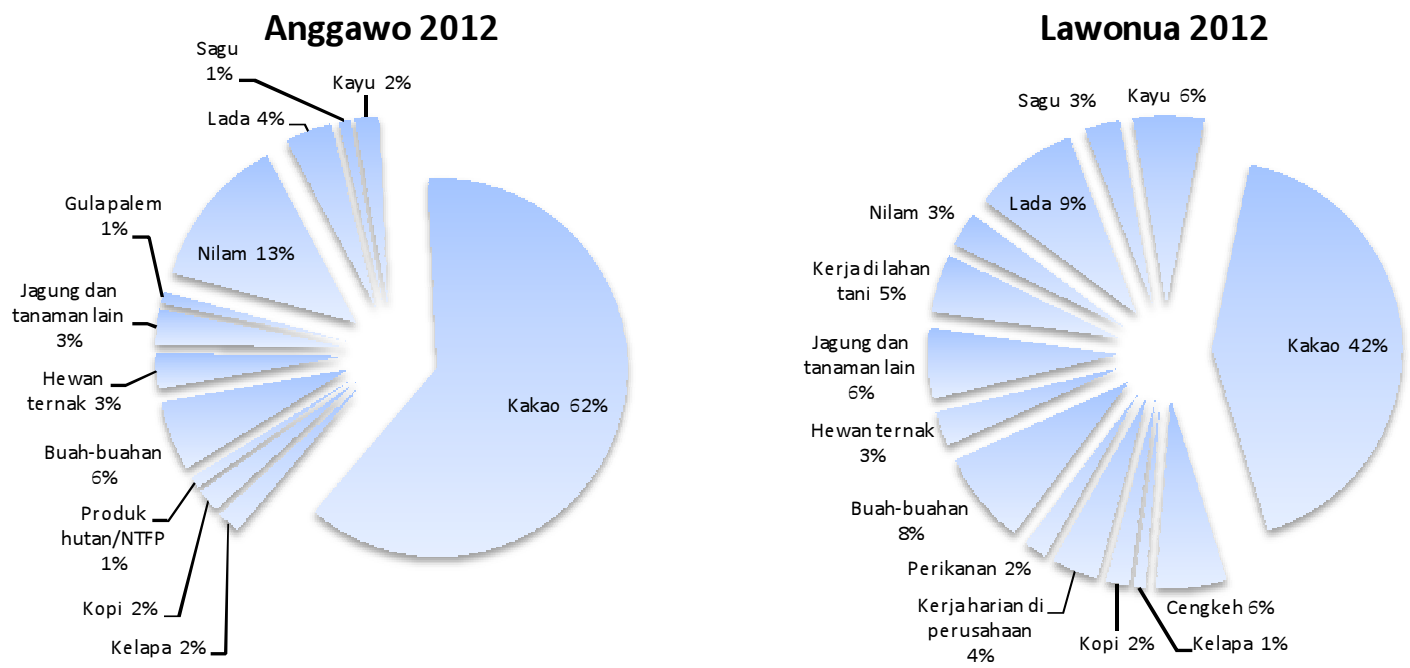

Gambar 41. Opsi mata pencaharian terkini di Anggawo dan Lawonua berdasarkan perspektif masyarakat

\section{Buah-buahan}

Pisang dan rambutan merupakan buah-buahan yang produktif, memberikan hasil produksi cepat. Kebun pisang dapat memproduksi hingga 8 tandan sebulan dengan harga eceran Rp 25000 per tandan di pasar. Rambutan (23-30 pohon) dapat menghasilkan Rp 1 juta per musim. Harga eceran sekitar Rp 30000 per karung (karung $50 \mathrm{~kg}$ ).

\subsection{Tipologi 3 (desa transmigran lama)}

Kakao dan lada merupakan tanaman dominan pada tipologi ini selain komoditas lain. Dalam desadesa ini, pertanian dilakukan lebih intensif dibandingkan desa tipologi lain.

\section{Kakao}

Perladangang berpindah umumnya dilakukan di tahap awal pembersihan lahan untuk budi daya kakao di Tasahea . Penanaman kakao menggunakan jarak 3 × $3 \mathrm{~m}$, dengan lubang tanam berukuran $40 \times 40 \times 40 \mathrm{~cm}$. Di awal, para petani menggunakan turunan dari bibit $\mathrm{F} 1$ atau menggunakan sambung samping.

Perawatan kakao yang dilakukan adalah:

- Pemupukan dua kali setahun (setiap 6 bulan) pada awal tanaman berbunga dan setelah panen. Pupuk yang digunakan adalah TSP, $\mathrm{KCl}$, dan urea, tergantung pada usia kakao. Pohon kakao di banyak kebun di Tasahea berusia hingga 12 tahun; para petani yakin dengan menggunakan pupuk mereka dapat meningkatkan hasil panen hingga beberapa ratus kilogram.

- Pemangkasan sanitasi dua kali setahun (memangkas cabang dan penyemprotan gulma)

- Penyemprotan insektisida, dari masa berbunga hingga panen, setiap 3 hingga 4 bulan

- Drainase sekali setahun 
Produktivitas kakao di desa ini cukup tinggi dibandingkan dengan desa-desa lain---1,5 ton per hektar per tahun dari pohon kakao berusia 7 tahun yang dipupuk sekali setahun. Bahkan pada usia 10 tahun, pohon-pohon ini masih dapat memproduksi hingga $800 \mathrm{~kg}$ per hektar per tahun. Kebanyakan kakao di desa dijual kepada perantara dengan harga Rp 15000 per kilogram.

\section{Tasahea 2012}

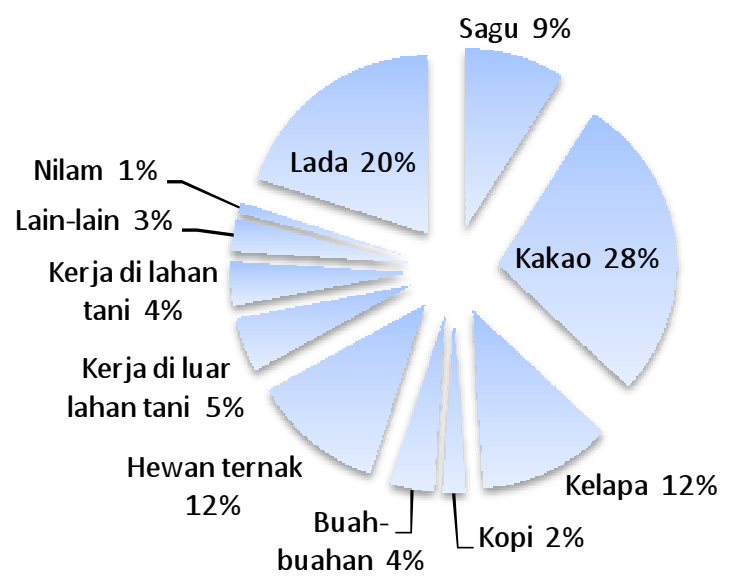

Gambar 42. Opsi mata pencaharian terkini di Tasahea berdasarkan persp ektif masyarakat

\section{Lada}

Banyak lada di Tasahea ditanam tumpangsari dengan kakao menggunakan jarak $3 \times 3 \mathrm{~m}$; pengaturan jarak tanam monokultur adalah $2 \times 3 \mathrm{~m}$. Beberapa petani mengintegrasikan lada di kebun rumah dengan kelapa. Perawatan lada meliputi:

- Pemangkasan batang pohon ajir dilakukan sekali dalam setahun

- Pemupukan sekali setahun berdasarkan praktik yang dilakukan petani

- Penyiangan 2 hingga 4 kali setahun

- Pengendalian hama dan penyakit dengan penyemprotan 3 kali setahun (semprotan dicampur dengan pupuk)

Berdasarkan pengalaman petani, 0,50 ha kebun lada (berusia 6 tahun) dapat memproduksi lebih dari $750 \mathrm{~kg}$ per panen. Kalau harga lada mencapai Rp 65 000, para petani mampu menghasilkan hingga Rp 50 juta.

\subsection{Tipologi 4 (desa transmigran baru)}

Budidaya kakao, produksi arang, dan kayu mendominasi pada tipologi ini. Buah adalah sumber pendapatan yang tidak terlalu dominan. Komoditas berbasis pohon lain seperti kakao masih pada tahap belum dewasa. Arnold dan Bird (1999) mengindikasikan pohon dan hutan memberikan banyak manfaat dalam bentuk produk dan layanan yang muncul dari penggunaan langsung dan tidak langsung. 


\section{Kakao}

Mirip dengan tipologi lain, ladang berpindah digunakan para petani pada fase pembukaan lahan untuk kebun kakao, biasanya dari September hingga Desember. Penanaman dilakukan pada awal musim hujan, pada Januari dan Februari. Umumnya, petani di Lalobite menanam kakao segera setelah lahannya siap, tetapi beberapa petani juga melakukan budi daya sayur sebelum kakao. Penanaman kakao diberi jarak $3,5 \times 3,5 \mathrm{~m}, 3 \times 3 \mathrm{~m}, 3 \times 4 \mathrm{~m}$, atau $2 \times 4 \mathrm{~m}$. Para petani mendapatkan bibit kakao lokal dari pohon induk yang sehat dan produktif.

Intensitas tingkat perawatan bervariasi bergantung pada keahlian pengelolaan para petani. Perawatan oleh petani pendatang di Lalobite relatif intensif, sesuai dengan penjelasan berikut:

- Pengendalian hama menggunakan pestisida dan pupuk daun; sebanyak 2 hingga 3 kali sebulan pada bulan pertama atau tahun pertama; perawatan lanjutan bergantung pada prevalensi hama tanaman itu.

- Menghilangkan gulma dengan herbisida: "Rambo" sekali sebulan dan penggunaan pestisida dua kali sebulan

- Memotong tunas mata air tanaman kakao dilakukan sekali dalam sebulan

- Pemupukan setidaknya dua kali setahun, menggunakan TSP, $\mathrm{KCl}$, dan urea

Kendala utamanya adalah:

- Hama: babi hutan dan monyet, hama penggerek batang, penyakit busuk buah (Phytophthora palmivora).

- Harga pupuk dan perlengkapan pertanian yang mahal

- Harga dan kualitas pasar yang rendah

\section{Arang}

Produksi arang adalah mata pencaharian yang penting untuk penduduk UPT Asinua Jaya. Pemukiman transmigran ini dibangun baru 4 tahun yang lalu, maka banyak tanaman yang ditanam masyarakat yang belum dewasa. Kayu nona adalah kayu terbaik untuk membuat arang.
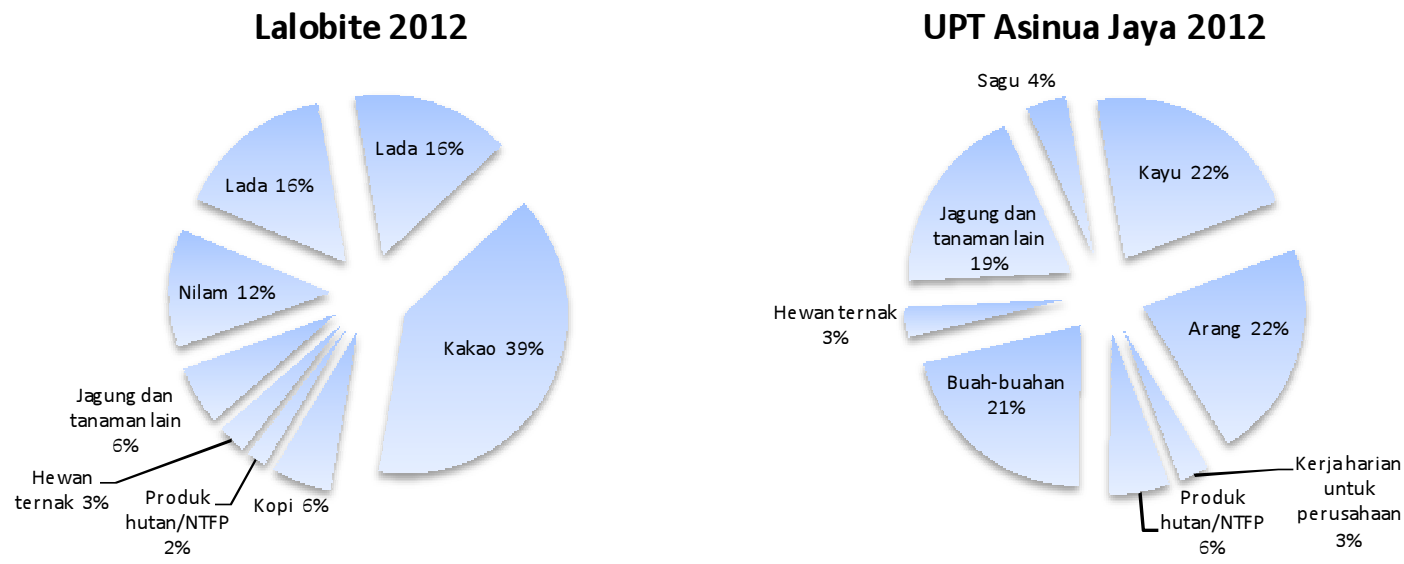

Gambar 43. Opsi mata pencaharian terkini di Lalobite dan UPT Asianua Jaya berdasarkan perspektif masyarakat 
$1 \mathrm{~m}^{3}$ kayu yang dibakar akan menghasilkan 10 karung arang yang dapat dijual dengan harga Rp 20000 - 23000 per karung kepada perantara dari Kolaka, Unaaha, dan Kendari yang berkunjung ke desa. Dalam 1 bulan, pembuat arang dapat meproduksi 70-100 karung arang. Biaya operasional terbesar adalah gergaji mesin untuk memotong kayu.

Diperkirakan dalam 2 tahun ke depan bisnis arang tidak akan berjalan lagi karena tingginya biaya dan beratnya kerja dalam bisnis ini.

\section{Kayu}

Para penduduk di UPT Asinua Jawa mendapatkan penghasilan dari pembalakan kayu. Ada permintaan tinggi untuk kolapi, ponto, kayu merah, dan kayu biti. Permintaan pemrosesan kayu terutama berasal dari luar desa seperti Unaaha.

Sekarang ini, lokasi pembalakan berada cukup jauh dari desa---10 km atau lebih. Karena biaya produksi seperti bensin, oli, transportasi, dan tenaga kerja cukup besar, maka permintaan yang nilainya besar saja yang dapat menghasilkan keuntungan bagi masyarakat, yaitu antara 5 hingga $10 \mathrm{~m}^{3}$ kayu.

\section{Buah-buahan}

Pisang adalah satu-satunya buah yang diproduksi di desa ini. Para petani menanam pisang di kebun rumah mereka atau tidak terlalu jauh dari rumah. Pembeli biasanya datang ke desa (ketika membeli arang, mereka juga membeli pisang). Kendala utama adalah pemasaran, kondisi jalan, dan moda transportasi yang terbatas.

\subsection{Indikator penting mata pencaharian berdasarkan survei rumah tangga}

\subsubsection{Sumber pendapatan}

Rumus dasar tentang pendapatan dari wiraswasta (dalam pertanian atau bisnis) adalah:

$$
I=\sum_{i=i}^{n} p_{i} y_{i}-\sum_{j=1}^{m} q_{j} v_{j}
$$

Pendapatan (income,I) adalah nilai bruto (harga dikalikan kuantitas semua produk $\mathrm{n}$ ) dikurangi biaya total (harga dikalikan kuantitas semua masukan $m$ yang dibeli), contohnya pupuk, benih, peralatan, tenaga kerja yang disewa (Angelsen dan Lund 2011).

Pendapatan total rata-rata per tahun per rumah tangga pada Tipologi 1 lebih rendah dibandingkan dengan tipologi-tipologi lain (Tabel 5 dan Gambar 44). Sumber pendapatan utama untuk petani di semua desa juga berbeda-beda: 
Tipologi 1: agroforestri kakao, buruh upahan, dan wiraswasta

Tipologi 2: agroforestri kakao, buruh upahan, dan kebun campur

Tipologi 3: agroforestri lada, agroforestri kakao, dan kebun campur

Tipologi 4: agroforestri kakao, arang, dan kayu

Perhitungan pendapatan yang dilakukan mencakup nilai semua komoditas yang dikonsumsi. Namun, pada umumnya pendapatan berasal dari tanaman berjangka pendek (Tabel 5 dan Gambar 44). 
Tabel 5. Rata-rata pendapatan masyarakat berdasarkan sumber pendapatan di Sulawesi Tenggara pada 2012

\begin{tabular}{|c|c|c|c|c|c|c|c|c|c|c|c|c|}
\hline \multirow{4}{*}{ Sumber pendapatan } & \multicolumn{12}{|c|}{ Pendapatan rata-rata dalam rumah tangga } \\
\hline & \multicolumn{6}{|c|}{ Lokal } & \multirow{2}{*}{\multicolumn{2}{|c|}{$\begin{array}{c}\text { Lokal dan migran } \\
\text { Desa Lawonua }\end{array}$}} & \multirow{2}{*}{\multicolumn{2}{|c|}{$\begin{array}{c}\text { Transmigran } \\
\text { Desa Tasahea }\end{array}$}} & \multirow{2}{*}{\multicolumn{2}{|c|}{$\frac{\text { Migran }}{\text { Desa Lalobite }}$}} \\
\hline & \multicolumn{2}{|c|}{ Desa Wonua Hoa } & \multicolumn{2}{|c|}{ Desa Ambondiaa } & \multicolumn{2}{|c|}{ Desa Simbune } & & & & & & \\
\hline & Rupiah & $\%$ & Rupiah & $\%$ & Rupiah & $\%$ & Rupiah & $\%$ & Rupiah & $\%$ & Rupiah & $\%$ \\
\hline 1. Pertanian & 17.560 .932 & 56 & 19.509 .985 & 61 & 18.772 .872 & 59 & 16.972 .342 & 54 & 29.248 .054 & 67 & 19.472 .576 & 69 \\
\hline Sawah & 2.154 .492 & 6,8 & - & 0 & 0 & - & 0 & - & 2.265 .185 & 5,2 & 503.117 & 1,8 \\
\hline Ladang sayur & 2.971 .033 & 9,4 & 503.783 & 1,6 & 59.533 & 0,2 & 1.666 .283 & 5,3 & 57.667 & 0,1 & 2.590 .450 & 9,2 \\
\hline Agroforestri kakao & 7.527 .733 & 23,9 & 16.711 .943 & 52,7 & 12.060 .172 & 38 & 6.297 .482 & 19,9 & 9.587 .333 & 22,1 & 14.561 .926 & 51,6 \\
\hline Kebun campur (agroforestri) & 1.702 .474 & 5,4 & 881.250 & 2,8 & 2.134 .367 & 6,7 & 5.844 .607 & 18,4 & 4.947 .548 & 11,4 & 323.950 & 1,1 \\
\hline Kebun kayu & 411.733 & 1,3 & 142.242 & 0,4 & 17.000 & 0,1 & 2.286 & 0 & 148.033 & 0,3 & 0 & - \\
\hline Kebun lada & 2.042 .367 & 6,5 & - & 0 & 3.824 .400 & 12 & 2.152 .100 & 6,8 & 10.443 .005 & 24,1 & 780.433 & 2,8 \\
\hline Pertanian lainnya & 751.100 & 2,4 & 1.270 .767 & 4 & 677.400 & 2,1 & 1.009 .583 & 3,2 & 1.799 .283 & 4,1 & 712.700 & 2,5 \\
\hline 2. Non-pertanian & 13.918 .983 & 44,2 & 12.215 .933 & 39 & 13.003 .042 & 40,9 & 14.714 .153 & 46,4 & 14.137 .150 & 32,6 & 8.757 .117 & 31 \\
\hline Produk kehutanan & 28.800 & 0,1 & 2.822 .733 & 8,9 & 71.733 & 0,2 & 70.667 & 0,2 & 157.533 & 0,4 & 86.167 & 0,3 \\
\hline Kayu bakar & 804.350 & 2,6 & 913.367 & 2,9 & 848.800 & 2,7 & 977.667 & 3,1 & 844.133 & 1,9 & 1.012 .350 & 3,6 \\
\hline Buruh upahan & 2.690 .667 & 8,5 & 3.684 .767 & 11,6 & 3.854 .333 & 12,1 & 6.232 .853 & 19,7 & 4.614 .833 & 10,6 & 2.480 .667 & 8,8 \\
\hline Usaha & 5.863 .600 & 18,6 & 1.523 .067 & 4,8 & 4.115 .508 & 13 & 2.147 .000 & 6,8 & 1.755 .233 & 4 & 3.970 .800 & 14,1 \\
\hline Profesional & 1.929 .400 & 6,1 & 2.045 .333 & 6,4 & 2.884 .000 & 9,1 & 1.821 .467 & 5,7 & 1.680 .000 & 3,9 & 120.000 & 0,4 \\
\hline Lainnya & 1.622 .700 & 5,2 & 916.667 & 2,9 & 150.000 & 0,5 & 3.019 .500 & 9,5 & 3.468 .750 & 8 & 472.000 & 1,7 \\
\hline Kiriman & 979.467 & 3,1 & 310.000 & 1 & 1.078 .667 & 3,4 & 445.000 & 1,4 & 1.616 .667 & 3,7 & 615.133 & 2,2 \\
\hline 3. Pendapatan total per tahun & 31.479 .915 & 100 & 31.725 .918 & 100 & 31.775 .914 & 100 & 31.686 .495 & 100 & 43.385 .204 & 100 & 28.229 .693 & 100 \\
\hline
\end{tabular}




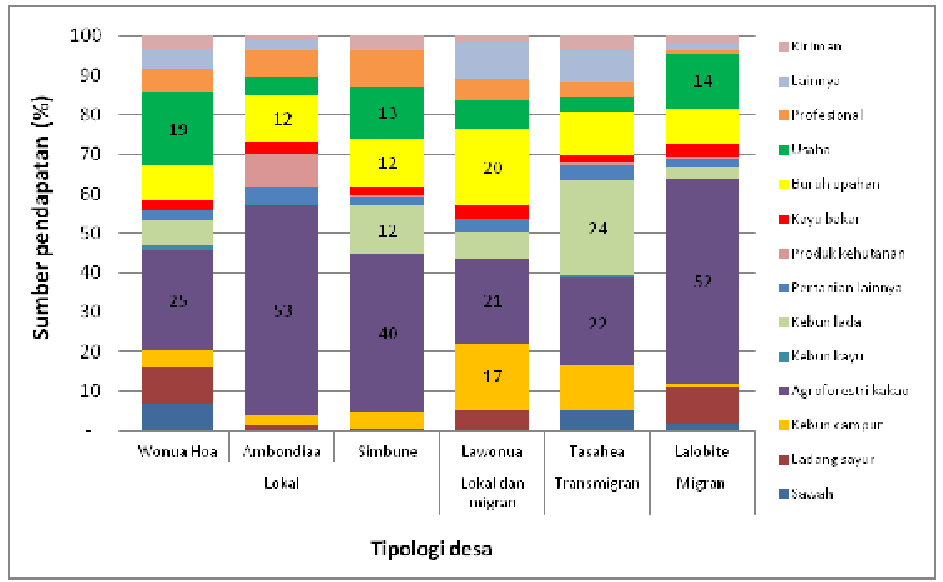

Gambar 44. Sumber pendapatan berdasarkan tipe kegiatan di Sulawesi Tenggara pada 2012

Gambar 45 menunjukkan sumber pendapatan umum dari kegiatan pertanian atau nonpertanian dan pertanian dalam semua tipologi.

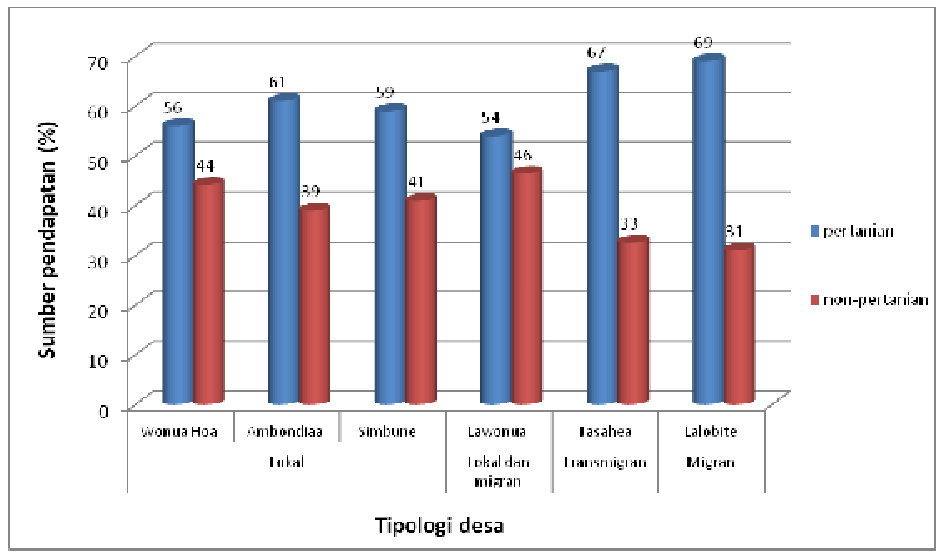

Gambar 45. Sumber pendapatan di Sulawesi Tenggara pada 2012

\subsubsection{Pendapatan per kapita}

Pendapatan per kapita petani Tipologi 1 lebih rendah daripada tipologi lain. Petani Tipologi 3 lebih kaya daripada petani pada tipologi lain. Pendapatan harian per kapita petani transmigran nyaris dua kali lipat petani Tipologi 1 (Gambar 46).

Pendapatan per kapita petani di Sulawesi Tenggara dijelaskan dalam Gambar 46. Menggunakan standar garis kemiskinan US\$1 per hari, persentase pendapatan petani di Sulawesi Tenggara berada di atas garis kemiskinan. 


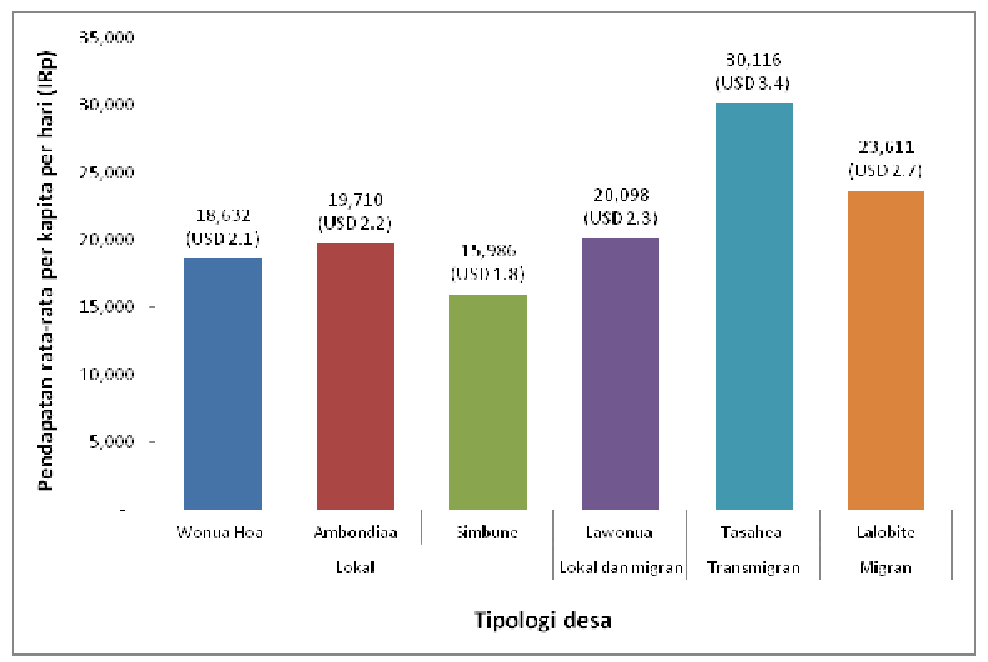

Gambar 46. Rata-rata pendapatan per kapita per hari masyarakat di Sulawesi Tenggara pada 2012

\subsubsection{Kepemilikan lahan}

Kepemilikan lahan rata-rata per rumah tangga Tipologi 1 (3,65 ha) lebih besar dibandingkan dengan Tipologi 4 (3,47 ha), Tipologi 2 (3,10 ha), dan Tipologi 3 (2,80 ha) (Gambar 47). Komposisi kepemilikan lahan berdasarkan tipe penggunaan lahan berbeda di seluruh lokasi (Tabel 6).

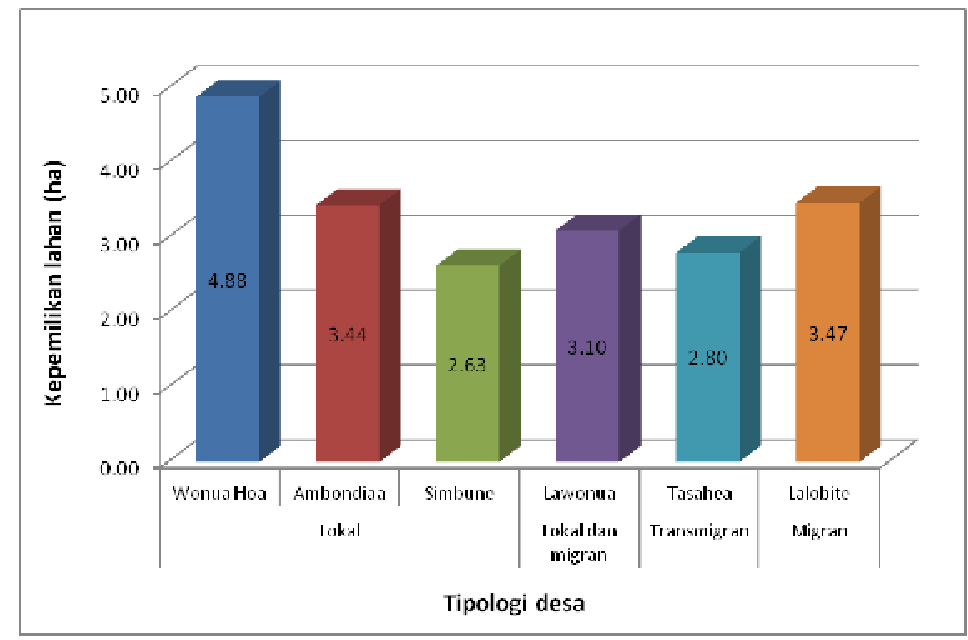

Gambar 47. Distribusi kepemilikan lahan rata-rata per rumah tangga di Sulawesi Tenggara 
Tabel 6. Distribusi luas penguasaan lahan berdasarkan penggunaan lahan di Sulawesi Tenggara

\begin{tabular}{|c|c|c|c|c|c|c|c|c|c|}
\hline \multirow[b]{2}{*}{$\begin{array}{l}\text { Tipologi } \\
\text { desa }\end{array}$} & \multirow[b]{2}{*}{ Desa } & \multicolumn{8}{|c|}{ Kepemilikan Iahan rata-rata berdasarkan penggunaan lahan ( $\mathrm{Ha})$} \\
\hline & & Sawah & $\begin{array}{l}\text { Ladang } \\
\text { sayur }\end{array}$ & $\begin{array}{l}\text { Agroforestri } \\
\text { kakao }\end{array}$ & $\begin{array}{l}\text { Kebun } \\
\text { campur }\end{array}$ & $\begin{array}{l}\text { Kebun } \\
\text { kayu }\end{array}$ & $\begin{array}{l}\text { Kebun } \\
\text { lada }\end{array}$ & $\begin{array}{c}\text { Semak } \\
\text { belukar }\end{array}$ & $\begin{array}{c}\text { Semak } \\
\text { belukar } \\
\text { untuk } \\
\text { sawit }\end{array}$ \\
\hline \multirow{3}{*}{ Lokal } & Wonua Hoa & 1,01 & 0,22 & 0,71 & 0,80 & 0,09 & 0,19 & 1,86 & 0,00 \\
\hline & Ambondiaa & 0,00 & 0,04 & 1,21 & 0,33 & 0,22 & 0,00 & 1,64 & 0,00 \\
\hline & Simbune & 0,02 & 0,02 & 1,11 & 0,27 & 0,03 & 0,09 & 1,09 & 0,00 \\
\hline $\begin{array}{l}\text { Lokal dan } \\
\text { migran }\end{array}$ & Lawonua & 0,00 & 0,13 & 0,79 & 0,93 & 0,09 & 0,18 & 0,75 & 0,23 \\
\hline Transmigran & Tasahea & 0,23 & 0,00 & 1,07 & 0,32 & 0,11 & 0,69 & 0,38 & 0,00 \\
\hline Migran & Lalobite & 0,09 & 0,33 & 1,45 & 0,29 & 0,00 & 0,11 & 1,20 & 0,00 \\
\hline
\end{tabular}

Penggunaan lahan utama di sejumlah desa di Sulawesi Tenggara adalah semak belukar. Alasan utama petani tidak menggarap lahan ini pada Tipologi 1 adalah kekurangan modal (50-88\%) dan tenaga kerja (8-37\%). Pada Tipologi 2 para petani menunggu untuk memanfaatkan lahan yang direncanakan akan dijadikan perkebunan kelapa sawit (35\%) dan juga terbatas akibat kekurangan tenaga kerja (29\%). Pada Tipologi 3 alasan petani tidak menggarap lahan adalah karena kekurangan modal (69\%) dan lahan tidak produktif (15\%). Enam puluh persen responden pada Tipologi 4 menyatakan kekurangan tenaga kerja dan 33\% kekurangan modal (Gambar 48).

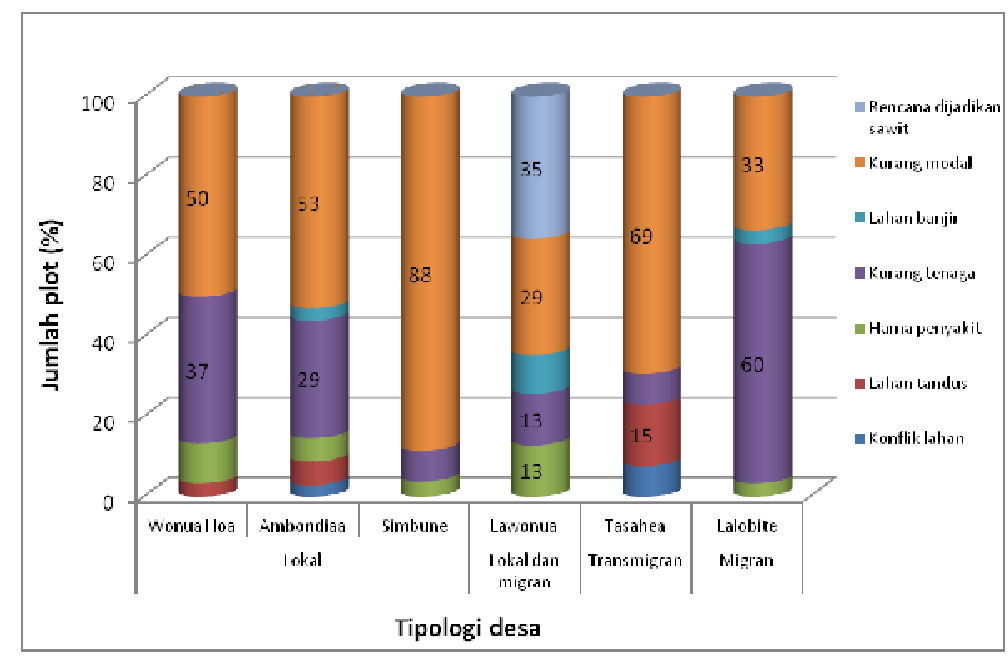

Gambar 48. Alasan lahan tidak digarap/dikosongkan di Sulawesi Tenggara

Pada umumnya, lama lahan semak belukar tidak digarap di desa-desa berlangsung kurang dari 15 tahun (27-37\%), lebih dari 15 tahun (20-47\%), dan 6-10 tahun (15-23\%) (Gambar 49). Pada Tipologi 2, lama lahan tidak digarap/dikosongkan berlangsung kurang dari 15 tahun (61\%) dan 11-15 tahun (26\%). Pada Tipologi 4, 67\% lahan tidak digarap/dikosongkan berusia kurang dari 15 tahun, dan 20\% berusia 6-10 tahun. Sementara pada Tipologi 3, 38\% lahan tidak digarap/dikosongkan berusia kurang dari 15 tahun, 38\% berusia lebih dari 15 tahun, dan 23\% berusia 11-15 tahun. 


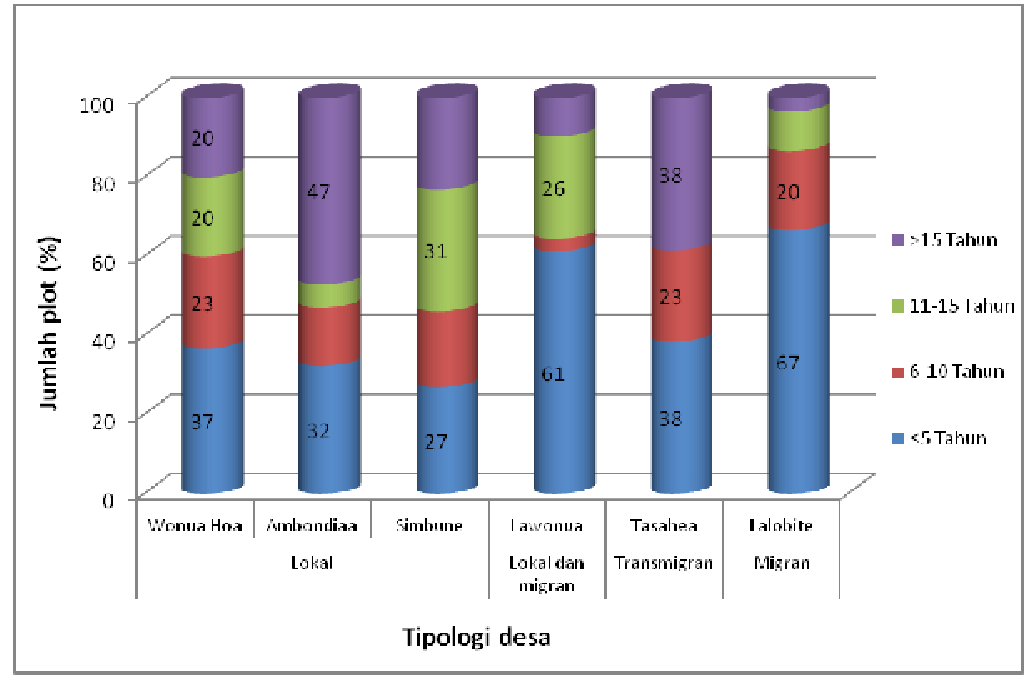

Gambar 49. Lama lahan tidak digarap/dikosongkan di Sulawesi Tenggara 


\section{Kesimpulan}

Keempat tipologi ini memiliki perbedaan dalam hal opsi mata pencaharian, tanaman pohon, dan sistem pengelolaan pertanian. Variasi-variasi ini disebabkan oleh pola pengelolaan lahan tradisional dan sistem pengelolaan petani, akses pasar, serta pengaruh pendatang di desa yang cukup besar.

Pada Tipologi 1, dinamika penggunaan lahan menunjukkan bahwa agroforestri kakao telah meningkat cukup tinggi selama 40 tahun terakhir, diikuti dengan penurunan tutupan hutan yang signifikan di desa. Di Wonua Hoa, selain agroforestri kakao, budi daya jagung dan padi meningkat dengan signifikan pada periode yang sama. Di Taosu, perkebunan kelapa sawit meluas. Tanaman lain pada tipologi ini adalah padi, nilam, sagu (makanan utama untuk suku Tolaki di daerah ini). Namun demikian, agroforestri kakao yang dilakukan tidak seintensif sistem yang digunakan pada Tipologi 2 .

Dinamika penggunaan lahan yang hampir sama juga ditemukan di Anggawo dan Lawonua (Tipologi 2) terkait dengan peningkatan pada agroforestri kakao dan penurunan tutupan hutan. Di Lawonua, beberapa perkebunan kelapa sawit dan agroforestri kakao baru mulai dibangun. Tipologi ini menunjukkan adanya pengaruh kuat dari masyarakat pendatang dari Sulawesi Selatan pada petani lokal, dimana masyarakat pendatang menerapkan sistem pertanian kakao yang cukup intensif disbanding masyarakt lokal. Para pendatang juga memperkenalkan kerbau untuk membajak sawah yang sebelumnya tidak dilakukan oleh masyarakat setempat.

Di Tasahea, desa transmigran lama (Tipologi 3), agroforestri kakao juga berkembang selama 40 tahun terakhir. Kecenderungan serupa terjadi pada Tipologi 4 yang juga kehilangan lahan tutupan hutan. Pendatang dari Sulawesi Selatan di Desa Lalobite hanya berfokus pada pengembangan kakao sebagai sumber pendapatan utama. Di desa yang baru terbentuk (UPT Asinua Jaya), tutupan hutan berkurang amat banyak selama 4 tahun terakhir akibat konversi hutan menjadi lahan semak dan kebun kakao kecil. Sebagai desa transmigran baru, UPT Asinua Jaya memiliki ketergantungan tinggi dari penghasilan yang berasal dari produk hutan dan hal ini menjadi sumber penghasilan utama mereka. Dalam kedua tipologi ini, jelas terlihat bahwa desa transmigran lama (Tipologi 3) memiliki sumber mata pencaharian lebih beragam yang bersumber pada kakao, lada, dan hewan ternak. Kebalikannya dengan UPT Asinua Jaya, desa transmigran baru (Tipologi 4), di mana sebagian besar masyarakat bergantung pada produk hutan sebagai sumber pendapatan utama (arang dan kayu) dan tidak terlalu bergantung pada tanaman perkebunan.

Kondisi rumah para petani pada Tipologi 4 lebih buruk dibandingkan dengan tipologi-tipologi lain, yang memiliki kondisi rumah relatif sama. Tipologi 4 juga memiliki tingkat pendidikan yang lebih rendah dibandingkan dengan ketiga tipologi lain, yang memiliki tingkat pencapaian pendidikan kurang lebih sama tetapi tingkat pendidikan perempuan sedikit lebih rendah.

Tanaman dan sumber pendapatan utama yang masih ada hingga hari ini adalah:

Tipologi 1: agroforestri kakao, buruh upahan, dan usaha wiraswasta

Tipologi 2: agroforestri kakao, buruh upahan, dan kebun campur

Tipologi 3: agroforestri lada, agroforestri kakao, dan kebun campur

Tipologi 4: agroforestri kakao, arang, dan kayu 
Pendapatan tahunan total per tahun per rumah tangga dan pendapatan harian per kapita pada tipologi 1 jauh lebih rendah dibandingkan dengan tipologi-tipologi lain. Tingkat pendapatan harian per kapita petani pada Tipologi 3 nyaris dua kali lipat pendapatan petani Tipologi 1.

Kepemilikan lahan rata-rata per rumah tangga pada Tipologi 1 (3,65 ha) lebih besar dibandingkan Tipologi 4 (3,47 ha), Tipologi 2 (3,10 ha) dan Tipologi 3 (2,80 ha). Penggunaan lahan utama adalah semak belukar pada Tipologi 1 (1,09-1,86 ha), agroforestri pada Tipologi 2 (0,93 ha), agroforestri kakao pada Tipologi 3 (1,07 ha), dan agroforestri kakao (1,45 ha) dengan semak belukar (1,20 ha) pada Tipologi 4.

\section{Rekomendasi}

- Melakukan penyuluhan pertanian komprehensif, mulai dari teknik pertanian terapan hingga pengendalian hama dan penyakit.

- Meningkatkan akses pada dan pengetahuan mengenai bibit dengan kualitas yang ditingkatkan/lebih baik untuk semua tanaman berpotensi.

- Mendirikan usaha mikro untuk mendorong ekonomi setempat dan mengurangi ketergantungan akan perantara dalam pemasaran produk pertanian.

- Meragamkan tanaman perkebunan (contoh, karet).

- Mentransfer teknologi pascapanen yang tepat seperti teknik pengeringan untuk kakao; meningkatkan pengembangan kapasitas untuk petani kakao.

- Melakukan kunjungan silang kepada para petani untuk bertukar pengalaman.

- Melakukan uji coba di lahan tanam untuk kakao dan beragam tanaman perkebunan. 


\section{Referensi}

Angelsen A, Lund, J-F. 2011. Designing the household questionnaire. In: Angelsen A, Larsen HO, Lund JF, Smith-Hall C, Wunder S. 2011. Measuring livelihoods and environmental dependence: methods for research and fieldwork. Washington: Earthscan.

Arnold JEM. 2001. Forest and people: 25 years of community forestry. Rome: Food and Agriculture Organization of the United Nations.

Arnold JEM, Bird P. 1999. Forests and the poverty-environment nexus. UNDP/EC Expert Workshop on Poverty and the Environment, Brussels, January 20-21.

Badan Pusat Statistik (BPS). 2008. Sulawesi Tenggara Dalam Angka. Kendari, Indonesia: Badan Pusat Statistik Provinsi Sulawesi Tenggara.

Roshetko JM, Suyanto, Dewi S, Sunderland T, Purwanto E, Perdana A, Millang S, Yuliani L, Purnomosidhi P, Tarigan J, Martini E, Finlayson R, Dahlia L. 2012. Agroforestry and forestry in Sulawesi: Linking knowledge to action. AgFor-CIDA annual report of first year (April 201 1March 2012). Bogor, Indonesia: World Agroforestry Centre (ICRAF) SEA Regional Office. p 1102. 



\section{WORKING PAPERS IN THIS SERIES}

\section{5}

1. Agroforestry in the drylands of eastern Africa: a call to action

2. Biodiversity conservation through agroforestry: managing tree species diversity within a network of community-based, nongovernmental, governmental and research organizations in western Kenya.

3. Invasion of prosopis juliflora and local livelihoods: Case study from the Lake Baringo area of Kenya

4. Leadership for change in farmers organizations: Training report: Ridar Hotel, Kampala, 29th March to 2nd April 2005.

5. Domestication des espèces agroforestières au Sahel : situation actuelle et perspectives

6. Relevé des données de biodiversité ligneuse: Manuel du projet biodiversité des parcs agroforestiers au Sahel

7. Improved land management in the Lake Victoria Basin: TransVic Project's draft report.

8. Livelihood capital, strategies and outcomes in the Taita hills of Kenya

9. Les espèces ligneuses et leurs usages: Les préférences des paysans dans le Cercle de Ségou, au Mali

10. La biodiversité des espèces ligneuses: Diversité arborée et unités de gestion du terroir dans le Cercle de Ségou, au Mali

\section{6}

11. Bird diversity and land use on the slopes of Mt. Kilimanjaro and the adjacent plains, Tanzania

12. Water, women and local social organization in the Western Kenya Highlands

13. Highlights of ongoing research of the World Agroforestry Centre in Indonesia

14. Prospects of adoption of tree-based systems in a rural landscape and its likely impacts on carbon stocks and farmers' welfare: The FALLOW Model Application in Muara Sungkai, Lampung, Sumatra, in a 'Clean Development Mechanism' context

15. Equipping integrated natural resource managers for healthy Agroforestry landscapes.

17. Agro-biodiversity and CGIAR tree and forest science: approaches and examples from Sumatra.

18. Improving land management in eastern and southern Africa: A review of policies.

19. Farm and household economic study of Kecamatan Nanggung, Kabupaten Bogor, Indonesia: A socio-economic base line study of Agroforestry innovations and livelihood enhancement.

20. Lessons from eastern Africa's unsustainable charcoal business.

21. Evolution of RELMA's approaches to land management: Lessons from two decades of research and development in eastern and southern Africa

22. Participatory watershed management: Lessons from RELMA's work with farmers in eastern Africa.

23. Strengthening farmers' organizations: The experience of RELMA and ULAMP.

24. Promoting rainwater harvesting in eastern and southern Africa.

25. The role of livestock in integrated land management.

26. Status of carbon sequestration projects in Africa: Potential benefits and challenges to scaling up.

27. Social and Environmental Trade-Offs in Tree Species Selection: A Methodology for Identifying Niche Incompatibilities in Agroforestry [Appears as AHI Working Paper no. 9]

28. Managing tradeoffs in agroforestry: From conflict to collaboration in natural resource management. [Appears as AHI Working Paper no. 10]

29. Essai d'analyse de la prise en compte des systemes agroforestiers pa les legislations forestieres au Sahel: Cas du Burkina Faso, du Mali, du Niger et du Senegal.

30. Etat de la recherche agroforestière au Rwanda etude bibliographique, période 1987-2003 


\section{7}

31. Science and technological innovations for improving soil fertility and management in Africa: A report for NEPAD's Science and Technology Forum.

32. Compensation and rewards for environmental services.

33. Latin American regional workshop report compensation.

34. Asia regional workshop on compensation ecosystem services.

35. Report of African regional workshop on compensation ecosystem services.

36. Exploring the inter-linkages among and between compensation and rewards for ecosystem services CRES and human well-being

37. Criteria and indicators for environmental service compensation and reward mechanisms: realistic, voluntary, conditional and pro-poor

38. The conditions for effective mechanisms of compensation and rewards for environmental services.

39. Organization and governance for fostering Pro-Poor Compensation for Environmental Services.

40. How important are different types of compensation and reward mechanisms shaping poverty and ecosystem services across Africa, Asia \& Latin America over the Next two decades?

41. Risk mitigation in contract farming: The case of poultry, cotton, woodfuel and cereals in East Africa.

42. The RELMA savings and credit experiences: Sowing the seed of sustainability

43. Yatich J., Policy and institutional context for NRM in Kenya: Challenges and opportunities for Landcare.

44. Nina-Nina Adoung Nasional di So! Field test of rapid land tenure assessment (RATA) in the Batang Toru Watershed, North Sumatera.

45. Is Hutan Tanaman Rakyat a new paradigm in community based tree planting in Indonesia?

46. Socio-Economic aspects of brackish water aquaculture (Tambak) production in Nanggroe Aceh Darrusalam.

47. Farmer livelihoods in the humid forest and moist savannah zones of Cameroon.

48. Domestication, genre et vulnérabilité : Participation des femmes, des Jeunes et des catégories les plus pauvres à la domestication des arbres agroforestiers au Cameroun.

49. Land tenure and management in the districts around Mt Elgon: An assessment presented to the Mt Elgon ecosystem conservation programme.

50. The production and marketing of leaf meal from fodder shrubs in Tanga, Tanzania: A pro-poor enterprise for improving livestock productivity.

51. Buyers Perspective on Environmental Services (ES) and Commoditization as an approach to liberate ES markets in the Philippines.

52. Towards Towards community-driven conservation in southwest China: Reconciling state and local perceptions.

53. Biofuels in China: An Analysis of the Opportunities and Challenges of Jatropha curcas in Southwest China.

54. Jatropha curcas biodiesel production in Kenya: Economics and potential value chain development for smallholder farmers

55. Livelihoods and Forest Resources in Aceh and Nias for a Sustainable Forest Resource Management and Economic Progress

56. Agroforestry on the interface of Orangutan Conservation and Sustainable Livelihoods in Batang Toru, North Sumatra. 
58. Assessing the Hydrological Situation of Talau Watershed, Belu Regency, East Nusa Tenggara.

59. Kajian Kondisi Hidrologis DAS Talau, Kabupaten Belu, Nusa Tenggara Timur.

60. Kajian Kondisi Hidrologis DAS Kapuas Hulu, Kabupaten Kapuas Hulu, Kalimantan Barat.

61. Lessons learned from community capacity building activities to support agroforest as sustainable economic alternatives in Batang Toru orang utan habitat conservation program (Martini, Endri et al.)

62. Mainstreaming Climate Change in the Philippines.

63. A Conjoint Analysis of Farmer Preferences for Community Forestry Contracts in the Sumber Jaya Watershed, Indonesia.

64. The highlands: a shared water tower in a changing climate and changing Asia

65. Eco-Certification: Can It Deliver Conservation and Development in the Tropics.

66. Designing ecological and biodiversity sampling strategies. Towards mainstreaming climate change in grassland management.

67. Towards mainstreaming climate change in grassland management policies and practices on the Tibetan Plateau

68. An Assessment of the Potential for Carbon Finance in Rangelands

69 ECA Trade-offs Among Ecosystem Services in the Lake Victoria Basin.

69. The last remnants of mega biodiversity in West Java and Banten: an in-depth exploration of RaTA (Rapid Land Tenure Assessment) in Mount Halimun-Salak National Park Indonesia

70. Le business plan d'une petite entreprise rurale de production et de commercialisation des plants des arbres locaux. Cas de quatre pépinières rurales au Cameroun.

71. Les unités de transformation des produits forestiers non ligneux alimentaires au Cameroun. Diagnostic technique et stratégie de développement Honoré Tabuna et Ingratia Kayitavu.

72. Les exportateurs camerounais de safou (Dacryodes edulis) sur le marché sous régional et international. Profil, fonctionnement et stratégies de développement.

73. Impact of the Southeast Asian Network for Agroforestry Education (SEANAFE) on agroforestry education capacity.

74. Setting landscape conservation targets and promoting them through compatible land use in the Philippines.

75. Review of methods for researching multistrata systems.

76. Study on economic viability of Jatropha curcas L. plantations in Northern Tanzania assessing farmers' prospects via cost-benefit analysis

77. Cooperation in Agroforestry between Ministry of Forestry of Indonesia and International Center for Research in Agroforestry

78. "China's bioenergy future. an analysis through the Lens if Yunnan Province

79. Land tenure and agricultural productivity in Africa: A comparative analysis of the economics literature and recent policy strategies and reforms

80. Boundary organizations, objects and agents: linking knowledge with action in agroforestry watersheds

81. Reducing emissions from deforestation and forest degradation (REDD) in Indonesia: options and challenges for fair and efficient payment distribution mechanisms

82. Mainstreaming climate change into agricultural education: challenges and perspectives

83. Challenging conventional mindsets and disconnects in conservation: the emerging role of ecoagriculture in Kenya's landscape mosaics

84. Lesson learned RATA garut dan bengkunat: suatu upaya membedah kebijakan pelepasan kawasan hutan dan redistribusi tanah bekas kawasan hutan

85. The emergence of forest land redistribution in Indonesia

86. Commercial opportunities for fruit in Malawi

87. Status of fruit production processing and marketing in Malawi 
88. Fraud in tree science

89. Trees on farm: analysis of global extent and geographical patterns of agroforestry

90. The springs of Nyando: water, social organization and livelihoods in Western Kenya

91. Building capacity toward region-wide curriculum and teaching materials development in agroforestry education in Southeast Asia

92. Overview of biomass energy technology in rural Yunnan (Chinese - English abstract)

93. A pro-growth pathway for reducing net GHG emissions in China

94. Analysis of local livelihoods from past to present in the central Kalimantan Ex-Mega Rice Project area

95. Constraints and options to enhancing production of high quality feeds in dairy production in Kenya, Uganda and Rwanda

\section{0}

96. Agroforestry education in the Philippines: status report from the Southeast Asian Network for Agroforestry Education (SEANAFE)

97. Economic viability of Jatropha curcas L. plantations in Northern Tanzania- assessing farmers' prospects via cost-benefit analysis.

98. Hot spot of emission and confusion: land tenure insecurity, contested policies and competing claims in the central Kalimantan Ex-Mega Rice Project area

99. Agroforestry competences and human resources needs in the Philippines

100. CES/COS/CIS paradigms for compensation and rewards to enhance environmental Services

101. Case study approach to region-wide curriculum and teaching materials development in agroforestry education in Southeast Asia

102. Stewardship agreement to reduce emissions from deforestation and degradation (REDD): Lubuk Beringin's Hutan Desa as the first village forest in Indonesia

103. Landscape dynamics over time and space from ecological perspective

104. Komoditisasi atau koinvestasi jasa lingkungan: skema imbal jasa lingkungan program peduli sungai di DAS Way Besai, Lampung, Indonesia

105. Improving smallholders' rubber quality in Lubuk Beringin, Bungo district, Jambi province, Indonesia: an initial analysis of the financial and social benefits

106. Rapid Carbon Stock Appraisal (RACSA) in Kalahan, Nueva Vizcaya, Philippines

107. Tree domestication by ICRAF and partners in the Peruvian Amazon: lessons learned and future prospects in the domain of the Amazon Initiative eco-regional program

108. Memorias del Taller Nacional: "Iniciativas para Reducir la Deforestación en la region Andino Amazónica", 09 de Abril del 2010. Proyecto REALU Peru

109. Percepciones sobre la Equidad y Eficiencia en la cadena de valor de REDD en Perú -Reporte de Talleres en Ucayali, San Martín y Loreto, 2009. Proyecto REALU-Perú.

110. Reducción de emisiones de todos los Usos del Suelo. Reporte del Proyecto REALU Perú Fase 1

111. Programa Alternativas a la Tumba-y-Quema (ASB) en el Perú. Informe Resumen y Síntesis de la Fase II. 2da. versión revisada

112. Estudio de las cadenas de abastecimiento de germoplasma forestal en la amazonía Boliviana

113. Biodiesel in the Amazon

114. Estudio de mercado de semillas forestales en la amazonía Colombiana

115. Estudio de las cadenas de abastecimiento de germoplasma forestal en Ecuador

116. How can systems thinking, social capital and social network analysis help programs achieve impact at scale?

117. Energy policies, forests and local communities in the Ucayali Region, Peruvian Amazon

118. NTFPs as a Source of Livelihood Diversification for Local Communities in the Batang Toru Orangutan Conservation Program

119. Studi Biodiversitas: Apakah agroforestry mampu mengkonservasi keanekaragaman hayati di DAS Konto? 
120. Estimasi Karbon Tersimpan di Lahan-lahan Pertanian di DAS Konto, Jawa Timur

121. Implementasi Kaji Cepat Hidrologi (RHA) di Hulu DAS Brantas, Jawa Timur.

122. Kaji Cepat Hidrologi di Daerah Aliran Sungai Krueng Peusangan, NAD,Sumatra

123. A Study of Rapid Hydrological Appraisal in the Krueng Peusangan Watershed, NAD, Sumatra.

\section{1}

124. An Assessment of farm timber value chains in Mt Kenya area, Kenya

125. A Comparative financial analysis of current land use systems and implications for the adoption of improved agroforestry in the East Usambaras, Tanzania

126. Agricultural monitoring and evaluation systems

127. Challenges and opportunities for collaborative landscape governance in the East Usambara Mountains, Tanzania

128. Transforming Knowledge to Enhance Integrated Natural Resource Management Research, Development and Advocacy in the Highlands of Eastern Africa

129. Carbon-forestry projects in the Philippines: potential and challenges The Mt Kitanglad Range forest-carbon development

130. Carbon forestry projects in the Philippines: potential and challenges. The Arakan Forest Corridor forest-carbon project

131. Carbon-forestry projects in the Philippines: potential and challenges. The Laguna Lake Development Authority's forest-carbon development project

132. Carbon-forestry projects in the Philippines: potential and challenges. The Quirino forest-carbon development project in Sierra Madre Biodiversity Corridor

133. Carbon-forestry projects in the Philippines: potential and challenges. The Ikalahan ancestral domain forest-carbon development

134. The Importance of Local Traditional Institutions in the Management of Natural Resources in the Highlands of Eastern Africa

135. Socio-economic assessment of irrigation pilot projects in Rwanda

136. Performance of three rambutan varieties (Nephelium lappaceum L.) on various nursery media

137. Climate change adaptation and social protection in agroforestry systems: enhancing adaptive capacity and minimizing risk of drought in Zambia and Honduras

138. Does value chain development contribute to rural poverty reduction? Evidence of asset building by smallholder coffee producers in Nicaragua

139. Potential for biofuel feedstock in Kenya

140. Impact of fertilizer trees on maize production and food security in six districts of Malawi.

\section{2}

141. Fortalecimiento de capacidades para la gestión del Santuario Nacional Pampa Hermosa:

Construyendo las bases para un manejo adaptativo para el desarrollo local. Memorias del Proyect

142. Understanding rural institutional strengthening: A cross-level policy and institutional framework for sustainable development in Kenya

143. Climate change vulnerability of agroforestry

144. Rapid assesment of the inner Niger delta of Mali

145. Designing an incentive program to reduce on-farm deforestationin the East Usambara Mountains, Tanzania

146. Extent of adoption of conservation agriculture and agroforestry in Africa: the case of Tanzania, Kenya, Ghana, and Zambia 
147. Policy incentives for scaling up conservation agriculture with trees in Africa: the case of Tanzania, Kenya, Ghana and Zambia

148. Commoditized or co-invested environmental services? Rewards for environmental services scheme: River Care program Way Besai watershed, Lampung, Indonesia.

149. Assessment of the headwaters of the Blue Nile in Ethiopia.

150. Assessment of the uThukela Watershed, Kwazaulu.

151. Assessment of the Oum Zessar Watershed of Tunisia.

152. Assessment of the Ruwenzori Mountains in Uganda.

153. History of agroforestry research and development in Viet Nam. Analysis of research opportunities and gaps.

154. REDD+ in Indonesia: a Historical Perspective

155. Agroforestry and Forestry in Sulawesi series: Livelihood strategies and land use system dynamics in South Sulawesi

156. Agroforestry and Forestry in Sulawesi series: Livelihood strategies and land use system dynamics in Southeast Sulawesi.

157. Agroforestry and Forestry in Sulawesi series: Profitability and land-use systems in South and Southeast Sulawesi.

158. Agroforestry and Forestry in Sulawesi series: Gender, livelihoods and land in South and Southeast Sulawesi

159. Agroforestry and Forestry in Sulawesi series: Agroforestry extension needs at the community level in AgFor project sites in South and Southeast Sulawesi, Indonesia.

160. Agroforestry and Forestry in Sulawesi series: Rapid market appraisal of agricultural, plantation and forestry commodities in South and Southeast Sulawesi.

\section{3}

161. Diagnosis of farming systems in the Agroforestry for Livelihoods of Smallholder farmers in Northwestern Viet Nam project

162. Ecosystem vulnerability to climate change: a literature review

163. Local capacity for implementing payments for environmental services schemes: lessons from the RUPES project in northeastern Viet Nam

164. Agroforestry dan Kehutanan di Sulawesi: Strategi mata pencaharian dan dinamika sistem penggunaan lahan di Sulawesi Selatan 

The World Agroforestry Centre is an autonomous, non-profit research organization whose vision is a rural transformation in the developing world as smallholder households increase their use of trees in agricultural landscapes to improve food security, nutrition, income, health, shelter, social cohesion, energy resources and environmental sustainability. The Centre generates science-based knowledge about the diverse roles that trees play in agricultural landscapes, and uses its research to advance policies and practices, and their implementation that benefit the poor and the environment. It aims to ensure that all this is achieved by enhancing the quality of its science work, increasing operational efficiency, building and maintaining strong partnerships, accelerating the use and impact of its research, and promoting greater cohesion, interdependence and alignment within the organization.

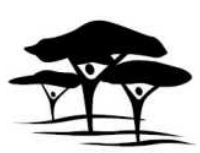

United Nations Avenue, Gigiri • PO Box $30677 \cdot$ Nairobi, $00100 \cdot$ Kenya Telephone: +254207224000 or via USA +16508336645 Fax: +254207224001 or via USA +1 6508336646

Email: worldagroforestry@cgiar.org•www.worldagroforestry.org

Southeast Asia Regional Program - Sindang Barang, Bogor 16680 PO Box 161 Bogor 16001, Indonesia Tel: +62 2518625415 - Fax: +62 2518625416 